\title{
第14回日本肝臓学会東部会抄録
}

\author{
期日：昭和54年11月9，10日 \\ 会場：日経ホール \\ 会長：上 野 幸 久
}

\section{＜会長講演 >}

\section{HBsAg 持続陽性慢性肝疾患の経過ならびに予後について}

$$
\text { 三宿病院上野幸 久 }
$$

慢性肝炎の経過を長期にわたって観察し，その予後を 検討することは本症の難治性の実態を明らかにし，治療 適応あるいは治療効果の判定を行なうことに重要な資料 となるものである.

しかるに慢性肝炎の経過ならびに予後についての報告 は内外に数多くのるのがあるが，その結論は一定してい ない：それは病因により予後に差があるのは当然として む，その他に年踰，性別といった因子，さらにより大 きな要因として地理病理学的な相違を考虑する必要があ る. 一般に慢性肝炎はきわめて難治性であり, 肝硬变の 前段階となる疾患として理解され，欧米では活動性慢性 肝炎の 5 年生存率は70\%以下といら位化予後が悪い、し かしながら，わが国に和ける僈性肝炎の予後はむしろか なり良好であり，5年以内に肝不全などにより死亡する 症例はむしろ稀である。

我々は昭和48年度の難治性の肝炎調查研究班報告飞お いて，慢性肝炎の経過ならびに長期予後に関する臨床的 研究と題し，本症の予後が従来考党られていたよりる良 好であることを発表した。

その後 6 年を経過することにより，観察期間が 延長 し, 症例を重ねるに従って当時の結論の変更の必要性を 検討し，この機会に改めて報告する次第である.

\section{観察対象と方法}

病因により経過ならびに予後が大きく異なる可能性を 考慮し，B型肝炎ウイルスの持続感染によることが確実 な，HBs 抗原が 6 ケ月以上持続的に陽性であることが 確かめられた慢性肝炎に限定 L, HBs 抗原陰性群を対 照とした。な な括 HBs 抗原陽性群においては，肝硬変の
長期観察例も含めて対象とした.

HBs 持続陽性の総数は106例であり，全例 3 年以上の follow-up を行なった. そのうち 5 年以内のもの 31,5 $\sim 7$ 年のもの $36, \quad 7 \sim 10$ 年のもの $27, \quad 10 \sim 15$ 年のもの $8 ， 15$ 年以上 3 例であり，うち女性はわずか16例（15.2 \%)に過ぎない，一部少数例を除き，ほとんどは肝生検 よりささらに一部は腹腔鏡検査を併用して診断したもの である.

106例中非輸血例は101例であり，そのうち76例（75.2 \%) は急性肝炎の既往を欠く，いわ的る原発性慢性肝炎 であることは注目に值する。

なお HBs 抗原陽性例と陰性例との対比は 5 年以上観 察し得た慢性肝炎例に限定 L, 例数は前者61（女性 9), 後者145（女性40）である.

究極的な予後 (転帰) の判断を論ずるに当り，しばし ば形態学的立場から行なわれることが多いが，これは予 後良好な症例㶤ついて夷施が容易でなく実際的でない。 むしろ予後判断に当っては臨床的な状態を規準として行 ならことが妥当と考克られるので，演者らは最終観察时 点における状熊から治瘾, 要観察, 要治療, 入院および 死亡の 5 群に分類した. 一般的肝機能検査の正常化が 1 年以上持続しているものを治痹とし，膠質反応，トラン スアミナーゼの軽度の異常を認めるものの自覚症状に之 しく，日常生活に全く支障のない状態が持続しているも のを要観察とした，要治療とは中等度の肝機能異常が持 続あるいは弛張性を示するのの，自覚症状が 軽度であ り，多少の制約を受けることはあっても平常に近い社会 生活を営なんでいるものである. 


\section{成 績}

HBs 抗原陽性慢性肝炎の最終観察時点においてな特 慢性肝炎と診断されたものは66例(82.5\%)であり，肝硬 変々診断されたるのは14例(17.5\%)である。また肝硬変 19例中 6 例 (31.6\%) に肝癌が合併した. 慢性肝炎のま ま 3 年以上経過した66例中実に63例は臨床的には要観察 ないし治痖の状態にまで回復した。また初診時すでに肝 硬変であったもの，および経過とともに肝硬変となった bの合計27例（肝癌合併例索除く）のうち19例 (70\%) は形態的にはともかくも，機能面では年月の経過ととも に次第に改善され，臨床的治瘾ないし要観察の状態に到 達した.

これら症例の臨床的転帰を観察期間の長さによってみ ると，それが長くなるにつれて治庱例の占める率が高く なり，7年以上の症例では38例中19例と半数が HBs 抗 原の持続にもかかわらず治瘾している.

5 年以上観察した慢性肝炎のらち，HBs 抗原陽性群 と陰性群とを比較すると，陽性群61例中 31 例 (50\%) が 治疻したのに対し, 陰性群の治瘜例は145例中22例 (15.2 \%)であり，前者が高率であった，また陽性群では死亡 例が0であるのに対し，陰性群では10例 (6.9\%) が死 亡した.

な拈106例中 3 例ではあるが，HBs 抗原の陰性化 (RPHA 法) するのと相前後し, 肝機能検査は正常化 し，その後も再発をみていない.

\section{総括ならびに考按}

以上の成績からすると，慢性肝炎とくに HBs 抗原陽 性例の予後はかなり良好であり，2〜3年間にわたり， 臨床的ならびに組織学的に活動性の状態を持続したすの であっても漸次非活動性となり，約半数は臨床的に治痹 といった状態にまで到達する。この治瘾率は HBs 抗原 陰性例よりも明らかに高率であり，5年以上追跡した慢 性肝炎に限定してみてむ，陰性例の15.2\%に対し，陽性
例では $50.8 \%$ となっている.

このよりに演者らの HBs 抗原陽性慢性肝炎の治癒率 が諸家の報告に比し高い原因は明らかではないが，これ らの症例のらち, 低アルブミン血, 高 $\gamma$ グロブリン血を伴 なう，GOT，GPT の高度の上昇といった肝機能倹查の強 い異常を伴ない, 形態的に活動性の著しい, Summerskill のいわゆる CALD に相当するすのが少数であることが 一因と考えられる.

予後の点で最も問題となる死亡率であるが，当初慢性 肝炎と診断された80例の死亡が皆無であったことは注目 に值する．演者らの経験した活動性の著しい，進行性の HBs 抗原持続陽性例の5ち, 死亡例はすべて初診後 3 年 以内である，換言すれば，著しい活動性の慢性肝炎であ ってむ，3年以上を経過すれば病状が次第に改善され， 肝不全を来すよらな急性增悪のおそれがきわめて小さく なることを示唆している.ただし，死因として留意する 必要のあるのは肝癌の合併であり, 当初肝硬変之診断さ れた症例の $31.5 \%$ 亿肝癌の合併をみており, 肝癌の早期 発見の必要性が痛感されている.

な副腎皮質ステロイド，6MPによる治瓷も106例 中34例について行ない，一部に有効と思われる症例も経 験したが，投与方法，期間等について継続的に行なわれ なかったため，その効果について明らかな結論を下し得 なかった。

\section{結 論}

HBsAg 持続陽性慢性肝疾患は長期的にみたばあい， その予後は意外飞も極めて良く, 約 3 分の 1 は臨床的治 瘾们到達し, その他の大半のるのる多少の肝機能異常は 持続するものの, ほぼ完全に社会復帰して生活に支障 ないまた HBs 抗原陰性群よりも治澺傾向が強い。た だ肝硬変例に和いては，非活動性であっても，肝癌を合 併してくることが大きな問題である. 


\title{
シンポジウム 脂肪肝の諸問題
}

\author{
司会 岩村健一郎 (東海大学第 3 内科) \\ 遠藤 康夫（東京大学第 1 内科）
}

\section{1. 成 因}

聖マリアンナ医科大学第 2 内科 岡部 和彦 脂肪肝の発生機序には脂肪の過剩供給・脂肪組織から 肝への脂肪の動員, 肝での脂肪合成六進, 肝での脂肪酸 々化障害, 肝でのリポ蛋白合成障害とそれに伴ら脂肪の 血中への放出障害などがある.

各種代表的実験的脂肪肝すなわち高精望食，高脂肪 食 (必須脂肪酸群・非必須脂肪酸群)，高エタノール食 (Lieber の合成液体飼料)，D-ガラクトースアミン肝 障害,オロット酸投与などによる脂肪肝を作成した。

そして上記脂肪肝発生機序の立端か、機能的形態的比 較検討を行った。

測定項目：（A）生化学的，（1）肝：脂質及びその 脂酸構成，脂肪酸合成速度 ( ${ }^{3} \mathrm{H}$-water $の$ 脂酸へのとり 込及)，脂肪酸々化能 (parmitoyl-carnithine を基質とし た酸素電極法)，電子伝達系酵素，（2）副拿丸脂肪組 織：重量, 組織リパーゼ活性，(3）血清（血浆）：リポ 蛋白, FFA, cAMP, ChE, GOT • GPT, $ァ ミ$ ノ酸濃度,

（B）形態，（1）肝の光顕：Sudam IIIによる脂肪染 色 etc, (2) 肝の電影.

成結及び結論：1) 高紡質食では肝での脂肪酸合成・ 脂肪酸々化・リポ蛋白の生成の充進がみられるが時に脂 肪酸合成が㯪位飞作動し肝での脂肪変性が惹起される.

2）高脂肪食では肝での脂肪酸々化・リポ蛋白の生成 る促進されるが，肝への脂肪の供給が最も大きな因子と して作動する. 非必須脂肪酸食は必須脂肪酸食に比べ肝 での脂肪蓄積の度合が強く， $\mathrm{C}_{20 ; 4}$ の減少が目立つ.

3）アルュール性脂肪肝は肝での脂肪酸の合成六進 ・ 脂肪酸々化障害・リポ蛋白の生成障害と末梢脂肪組織か らの脂肪の動員が加重されるが脂肪酸々化障害の影響が 大きいと考られる.

4）ガラクトースフミン・オロット酸脂肪肝には共通 性があり，肝でのリポ蛋白の合成障害が顕著で，その他 脂肪酸合成亢進・脂肪酸酸化障害もみられる. 前者では さらに末梢脂肪の動員も加味される.

\section{2. 診断：a）血液生化学的異常} 東京大学第 1 内科 飯野 四郎 頻度の高い脂肪肝である(1) 肥满飞伴う（過栄養性） 脂肪肝70例，(2) アルコールによる脂肪肝 35 例，これに 対比させて, (3) 慢性肝炎50例を選び 鑑別点を解析乙 た. それぞれの診断は肝生検組織, 臨床経過によった。 また，(1)が全例男性であったので，(2)，(3)すすべて男性 例とし，フルコール性肝炎，慢性肝炎急性增悪期は除外 した. (3)はB型および非 B型を半数ずつとした。

平均年秢は(1)が36歳，(2)が46歳，(3)が37歳，赤血球数 は(1)が506万，(2)が447万，(3)が485万，へマトクリット 值は(1)が47\%，(2)が44\%，(3)が45\%，血清総タンパク量 は(1)が8.0, (2)か゚7.5，(3)が7.7,アルブミン量は(1)が4.8g, (2)が $4.0 \mathrm{~g}$ ，(3)が4.1g であった。血清酵素では，まず， GOT/GPT では GOT をx, GPT をy とすると, (1)で は $\mathrm{y}=1.23 \mathrm{x}+4.3$, (2)では $\mathrm{y}=0.42 \mathrm{x}+9.8$, (3)では $\mathrm{y}=$ $1.21 \mathrm{x}+6.5$ の一次回㷌直線が得られた，ALPは1(1) 8.4K.A., (2)で10.2, (3)で8.6, rGTP は(1)で80, (2)で 217, (3)で61, TTTは(1)で2.9, (2)で3.4, (3)で4.4, ZTT は(1)で6.3, (2)で7.7, (3)で9.8, 総コレステロール値は (1)で225，(2)で210，(3)で181，尿酸は(1)で7.4，(2)で7.0， (3)で6.4であった：その他，ICG 又は BSP は(1)で80 \%, (2), (3)で $2 / 3$ が異常, Ch-E は(1)で50\%, (2)で30\%の 症例で上昇していた、リポタンパク像は(1)でリb,IV，(2) ではIであった，易疲労感は(1)で60\%，(2)で75\%，(3)で 40\%で主訴の 1つとなり，肝腫は(1)は44\%，(2)で83\%， (3)で34\%に認められた。（1)での体重をみるとGOT . GPT 異常は肥满度が+ 9 80\%でみられ，その正常化 時は87〜131\%と個人差が大であった。

(1)では易疲労感が 6 割, 肝隀が 4 割あり，RBC，Alb, T. Chol, Ch-E の上昇, ICG 異常があり，GPT 優位 で, GOT・GPT の変動は少い。性差・個体差が大き い. (2)では $r$ GTP が上昇し，GOT 優位で，禁酒によ り著明に改善する。 


\section{b) 肝機能検査と形態}

東海大学第 3 内科 杉本 栄一，岩村健一郎 脂肪肝を確実に診断するためには肝生検にたよらざる を得ない現状にある。しかし，これと血液生化学的検查 所見との対比を行ないつつ, 脂肪肝診断の可能性を検討 する必要があるう．そのことから脂肪肝を中心とする代 謝もまたかなり解明されるはずであり，現にかなり明ら かにされた面すある.

最近 4 年間にわれわれが腹腔鏡および肝生検により脂 肪肝を確認した男子133例，女子44例，計177例を対象と し，脂肪肝の程度を肝小葉のそれぞれ中心帯，中間帯， 辺緑帯，全增に脂肪化がみとめられたものを高度，いず れかの二層の範国にわたるものを中等度，一層乃至散在 性のものを軽度に分け，また病因的には病因不詳101例, 糖尿病性52例，アルコール性21例，薬剤性 3 例であっ た. 肥満度20\%をこえたものは76\%，原因不陆例 47 例 $62 \%$ ，肥満度の高いものほど肝の脂肪化は高度であっ た、な和入院後の食事摂取量と体重との推移を観察した ところでは，過栄養を病因とし得る根拠を首肯せしめる 例は少ないように思われる.

この上らな症例の背景因子をふま京，血液生化学的検 査所見を比較検討すると，GOT<GPT の血清トランス アミナーゼ活性值の上昇, コリンェステラーゼ活性值上 昇, ビリルビン量の 軽度増加, アルブミン量の 軽度増 加, $\beta$-グロブリン扎よび $\beta$-脂蛋白の増量, BSP の排泄 遅延, GOTm 陽性および総胆汁酸量の増加などの所見 が脂肪肝の診断を可能ならしめる.

脂肪肝治療上の点から鑑別が重要な問題となるのは慢 性活動性肝炎であろう。そのためには GOTm 和よびュ リンエステラーゼ活性値の変動が 役立つように思われ る. また，血清総胆汁酸量扣よび各分画の变動もまた雨 者鑑別のための指標となり得る期待を抱かせるが，今後 検討をつつけたい。

\section{3. 臨床 : 経過予後を中心として}

$$
\text { 三宿病院内科佐藤源一郎 }
$$

昭和33年以来三宿病院々自衙隊中央病院にて肝生検を 行った 4,272例中352例， $8.2 \%$ K脂肪肝を認めた。脂肪 肝では症状が軽度であることから follow-up が困難で あり，今回100例について調査したか， 3 年以上経過を 観察し得たすのは39例である.この100例について臨床 検査所見を，39例について経過を検討した.
脂肪肝では TTT の異常値を示す例が過半数である. GOT . GPT に比較して $\gamma$-GTP の高值を示す例が多く その大部分はアルコール性である. Ch-E が低值を示す 症例は少なく，高值を示す症例がある.フルコール性で は禁酒したものは予後良好であるが大量の飲酒を続けた 2 例は死亡した．糖尿病性と肥満に伴うものでは肝機能 検查面では不変例が多く，糖尿病のコントロールが良好 の例，および肥満から標準体重にとなった例では肝機能 検查の正常化すみられ，脂肪肝そのわのの予後は一般に 良好である.

\section{〈特別発言〉}

\section{1. 脂肪肝の成因一とくに肥満} 岐阜大学第 1 内科武藤 泰敏 1974年以降, 日本人のカロリー摂取量は減少したが, な拉30\%に 1 日3,000 cal 以上しかも蛋白摄取量に比へ てカロリー摂取が多いというアンバランスが指摘され る. また，脂肪（とくに動物性）とアルコール摄取量は な括漸増傾向にある。このような栄殿学的背景からも肥 満, それに伴ら脂肪肝の発生を理解すべきであるう。

肝生検230例の 中で脂肪肝（小葉の $1 / 3$ 以上の脂肪沈 着）は36例 $(15.6 \%)$ で，肝炎，アルコール肝障害， 糖原病などを除いた原発性（過栄養性）脂肪肝は10例 (4.3\%)であった これらの症例は肥満 (9/10例)，付 き合い程度の飲酒歴 $(8 / 10), \mathrm{HBs}$ 抗原 $(3 / 10)$, 耐糖能 障害（9/10）を伴っていた。 また，成因に拘らず肝脂肪 沈着度 $(1 / 3$ 以上) と肥満 $(+10 \%$ 以上) との間に有意 の相関が認められた $\left(\mathrm{x}^{2}\right.$ 検定， $\left.\mathrm{p}<0.01\right)$ ． 肥満者39例 中22例 (56\%) に脂肪肝がみられたことになる.

脂肪肝の血浆 FFA，TC 和よび FFA は有意伭く， また血将脂質の日内変動を観察したところ，夜半から朝 方に FFA の有意の上昇，ついで TG の増加か゚観察さ れた。 また $\Sigma \mathrm{TG} / \Sigma \mathrm{FFA}$ (24時間の総和) 比が有意に低 下し，一方 LPL 活性に差がないことより，肝からの相 対的 TG 分泌低下が強く示唆された。

血浆 IRI，IRG レベルは脂肪肝で増加したが，ア ルギニン負荷による IRG の反応性, および glucagon 投与による cAMP，血塆の反対性は正常であった，一 方, glucagon 持続静注 (48時間絶食) とより，FFA 動 員はみられたが同時に血浆 TG はむしろ著減し，これ が Ketogenesis 亢進によることが示された. GTG 肥満 マウスでも外因性 glucagon が肝 Ketogenesis の元進を 
介して肝 TG 蓄積を有意㛾少させることが明らかに された：この"glucagon shift”の機構を解明し，同時に 減量後も残存する肝脂肪沈着に対して沿療的効果をむつ か否かについては今後の興味ある課題と思われる.

\section{2. 脂肪肝一病理の立場から}

$$
\text { 北里大学病理奥平 雅彦 }
$$

脂肪肝は肝に異常に多量に中性脂肪が蓄積した蔵器し ベルでの全体評価に基く病態である. 肝細胞涽肪滴が 出現する病態を表わす用語に脂肪変性，脂肪浸潤，脂肪 沈着, 脂肪顕現, 脂肪变態, 脂肪蓄積および脂肪化など が使われているが，これらの用語の含蓄の 相違をのべ た.

脂肪肝の病理組䅧学的判定規準は国際的にも明確なる のがない，肝細胞の脂肪化の病理組織学的評価と肝脂質 の化学的定量成續との間には高い相関性を認めたので, 「すべての肝小葉の $1 / 3$ 以上の領域にわたって，肝細胞 飞著明な脂肪滴の蓄積性变化をみ，その他には顕著な形 態学的異常を認めないるの」を訩断規準として提案し た.

高度の脂肪肝から肝硬変に䔟行する際の重要な基本的 変化の 1 つとして，高度な脂肪蓄積による肝細胞破壊と 類洞血行障害による肝細胞壊死を強調した.

\section{The Pathogenesis of Alcoholic Cirrhosis}

A Review Based on 4060 Bioptically Controlled Chronic Alcoholics

\section{H. Thaler*}

Due to the peculiarities of ethanol metabolism, liver damage, visible in the light microscope, occurs only after chronic, i.e. daily, intake of alcohol. While steatosis arises in a few weeks (4) and disappears in the same space of time when alcohol consumption is discontinued (7), alcoholic cirrhosis develops only after many years of chronic alcoholism (Fig. 1). According to a recent statistical survey cirrhosis already may originate from a daily intake of more than $60 \mathrm{~g}$ of pure alcohol in males and more than $20 \mathrm{~g}$ in femals $(5,9)$. With higher doses cirrhosis morbidity rises dramatically (Fig. 2).

Alcoholism is a main indication for liver biopsy. In our material, (10), among 22,995 bioptically investigated patienis were 4,060 chronic alcoholics

* H. Thaler, M.D., Prof., Wilhelminenspital der Stadt Wien, 4. Interne Abteilung, 37, Montleartstraße, A-1171 Vienna, Austria

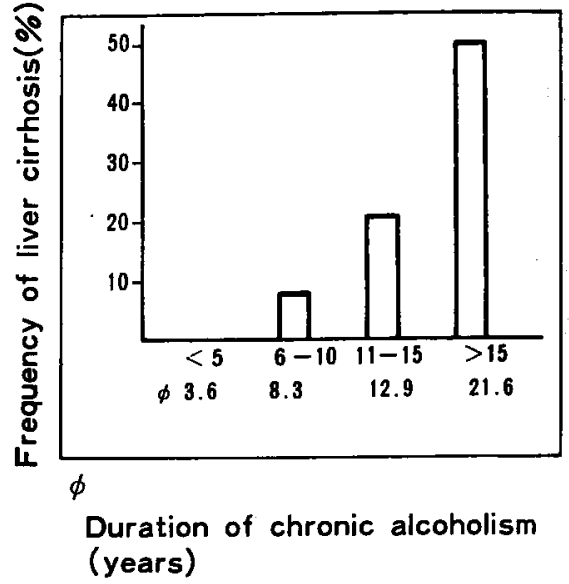

Fig. 1 Duration of chronic alcoholism and frequency of cirrhosis. (From H. Thaler (9), using figures of W.K. Lelbach (2)).

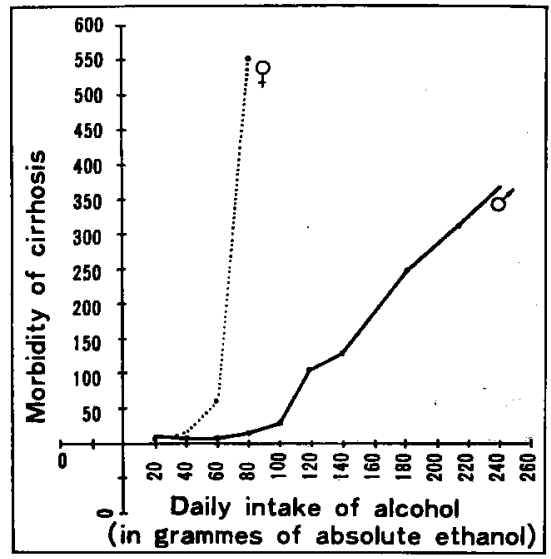

Fig. 2 Daily intake of ethanol and morbidity of cirrhosis in women and men. (From $H$. Thaler (9) using figures of G. Péquignot (5)).

$(17.7 \%$ ) (Tab. 1). 2,108 or $51.9 \%$ of them showed fatty liver. Alcoholic hepatitis was diagnosed in 1,256 patients $(30.9 \%)$. 675 presented alcoholic hepatitis with various degress of fibrosis but with preserved lobular architecture. In 579 drinkers there already was an aztive alcoholic cirrhosis, i.e. a nodular umbau of the liver together with the histological features of alcoholic hepatitis.

The frequency of some important characteristics of alcoholic hepatitis, observed in our material, is given in table 2 and 3. Alcoholic hepatitis without steatosis is an accidental finding often due to hospitalisation since its features need more time for regression than 
Table 1. Morphologic findings in chronic alcoholics

\begin{tabular}{|c|c|c|c|c|}
\hline & \multicolumn{2}{|c|}{$\mathrm{n}$} & \multicolumn{2}{|c|}{$\%$} \\
\hline $\begin{array}{l}\text { Fatty liver } \\
\text { Sclerosing fatty liver }\end{array}$ & $\left.\begin{array}{r}1874 \\
234\end{array}\right\}$ & 2108 & $\left.\begin{array}{r}46.2 \\
5.8\end{array}\right\}$ & 51.9 \\
\hline Alcoholic hepatitis & 675 & & 16.6 & \\
\hline Active alcoholic cirrhosis & 579 & & 14.3 & \\
\hline $\begin{array}{l}\text { Hepatocellular carcinoma } \\
\text { in active alcoholic } \\
\text { cirrhosis }\end{array}$ & 2 & 1256 & & 30.9 \\
\hline $\begin{array}{l}\text { Centrilobular fibrosis after } \\
\text { alcoholic hepatitis }\end{array}$ & 227 & & 5.6 & \\
\hline Inactive alcoholic cirrhosis & 326 & & 8.0 & \\
\hline $\begin{array}{l}\text { Hepatocellular carcinoma } \\
\text { in inactive alcoholic }\end{array}$ & & & & \\
\hline cirrhosis & 20 & & 0.5 & \\
\hline Normal liver & 34 & & 0.8 & \\
\hline Insufficient material & 89 & & 2.2 & \\
\hline$\therefore \quad \cdots$ & 4060 & & 100.0 & \\
\hline
\end{tabular}

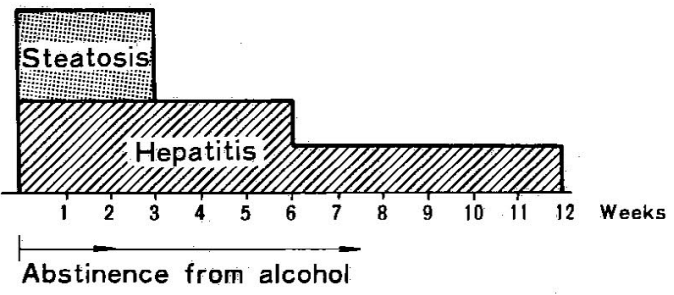

Fig. 3 Effect of withdrawal of ethanol on the regression of steatosis and the features of alcoholic hepatitis. (From H. Thaler (10)).

fatty change (Fig. 3). In our material the shortest interval for regression of alcoholic hepatitic was 42 days. The infiltration of the parenchyma with polymorphonuclear leukocytes is an inconstant finding. We noted it in $25 \%$ of precirrhotic cases of alcoholic hepatitis and in $40 \%$ of cirrhotic cases (Tab. 2 and 3 ). This difference is possibly due to the longer duration of the disease in patients with alcoholic cirrhosis. Polymorphonuclear infiltrates are exclusively related to Mallory body-containing hepatocytes (B) (Fig. 4). Doubtlessly, this "neutrophil satellitosis" is a secondary phenomenon and merely a scavanger-reaction. Sclerosing centrilobular necrosis of the parenchyma with little or no inflammatory reaction is a very characteristic lesion of alcoholic hepatitis. It is absent only in very early cases which present only ballooning and Mallory body-containing liver cells around the central vein (Fig. 5).

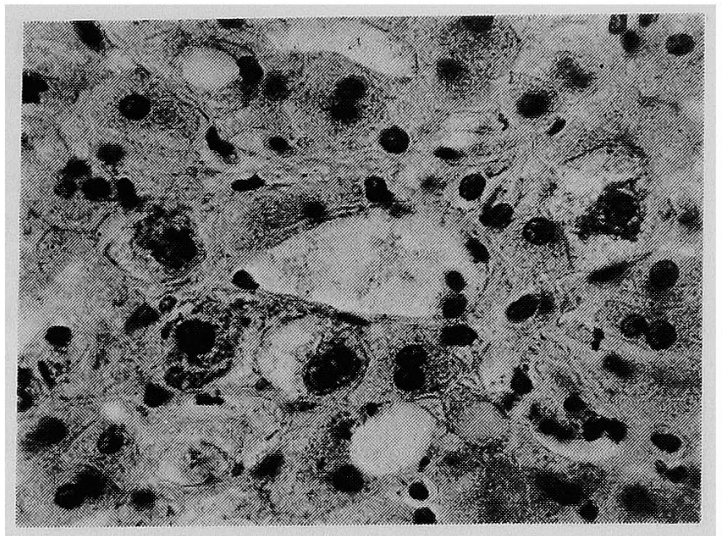

Fig. 4 Early (prenecrotic) alcoholic hepatitis. Ballooning liver cells, partly containing Mallory bodies, around the central vein. Chronic alcoholic, 44 year old man, H \& E, 450:1 (From H. Thaler $(10)$ ).

Table 4 shows the list of complicating liver diseases encountered in 1,254 cases of alcoholic hepatitis.

Serial biopsies were performed in 54 patients up to twelve per individual case. In 16 alcoholics, who were not able to stop their alcohol-abuse, the developement from alcoholic hepatitis to alcoholic cirrhosis could be followed. In 19 other patients, who abstained completely from alcohol, healing of alcoholic hepatitis with complete restitution or with centrilobular fibroses (so-called central hyalin necrosis) was noted (table 5).

In 227 patients $(5,8 \%)$, who did reduce their alcohol intake considerably or abstained from drinking before biopsy was performed, no alcoholic hepatitis but centrilobular fibrosis with or without various degrees of fatty changes were found. In 326 patients, former chronic alcoholics $(8 \%)$, biopsy reveiled inactive cirrhosis. 34 persons, who did not drink for the past three weeks or longer, had a normal liver.

Edmondson et al. (1) reported that centrilobular (perivenular) sclerosis, a fibrous rim around the central vein (terminal hepatic venula), can occur in alcoholic fatty liver in the absenze of alcoholic hepatitis. Lieber et al. (3) succeeded in the sequential production of fatty liver, hepatitis and cirrhosis in baboons by feeding ethanol with adequate albeit liquid diets. Centrilobular sclerosis was apparent before or even in the absence of alcoholic hepatitis. A similar Iesion was observed in fatty livers of chronic alcoholics (11).

The authors consider this sclerosis as a precursor lesion of cirrhosis and regard alcoholic hepatitis as 


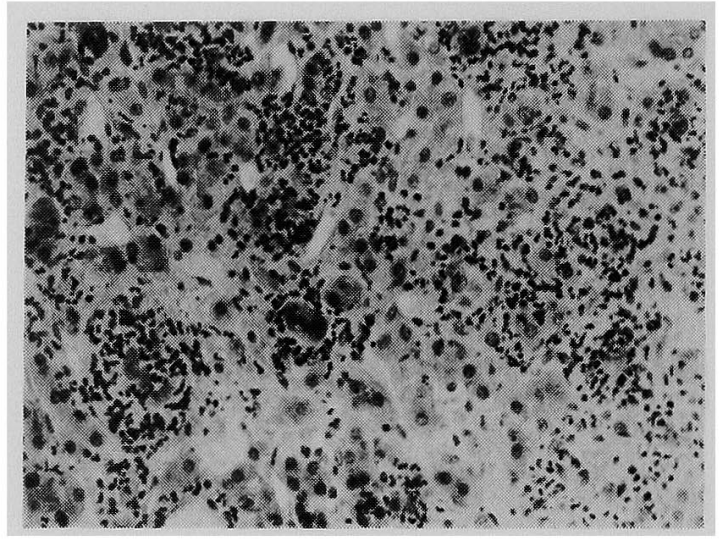

Fig. 5 Severe alcoholic hepatitis in a 46 year old chronic alcoholic woman. Polymorphonuclear leucocytic reaction around Mallory body-containing hepatocytes and a free Mallory body (right upper corner). H \& E, 60:1 (From H. Thaler (10)).

a relatively rare complication of chronic alcoholism. Therefore, Popper (5) claims a second, slower process of progression to alcoholic cirrhosis, due to the fibrogenetic effect of alcohol. Actually, mild sclerosis may be seen in alcoholic fatty livers which obviously is not caused by a preceeding alcoholic hepatitis. It consists of perivenular sclerosis, centrilobular pericellular fibrosis (chicken wire-fibrosis) and/or the formation of fine porto-portal or centro-portal fibrous septa which may be complete or uncomplete. We observed such a sclerosis in 234 cases, $5.8 \%$ of all chronic alcoholics or $11.1 \%$ of the alcoholic fatty livers. Eight of these cases were followed by serial biopsies. Up to five biopsies were performed. During a maximum control period of six years no progression of sclerosis to cirrhosis was noted despite continuing abuse of alcohol.

Based on these findings, it is concluded that alcoholic hepatitis is the usual and probably the inevitable precursor of alcoholic cirrhosis. Theoretically, it cannot be denied with certainty that alcoholic cirrhosis also may develop in fatty liver by simple collagenisation. However, if such an event really occurs it is certainly very rare.

\section{Summary}

4060 chronic alcoholics were studied by liver biopsies. Alcoholic cirrhosis originated exclusively from alcoholic hepatitis. In alcoholic fatty livers, a mild sclerosis without preceeding alcoholic hepatitis was observed but no transition of this lesion to cirrhosis was seen.

\section{Literature}

1) Edmondson, H.A., R.L. Peters, H.H. Frankel, et al.: The early stage of liver injury in the alcoholic. Medicine 46 (1967), 119.

2) Lelbach, W.K.: Leberschäden bei chronischem Alkoholismus. Teil III: Bioptisch-histologische Ergebnisse. Acta Hepatogastroenterol. (Stuttg.) 14 (1967), 9.

3) Lieber, C.S., L.M. De Carli, E. Rubin: Sequential production of fatty liver, hepatitis and cirrhosis in sub-human primates fed ethanol with adequate diets. Proc. Nat. Acad. Sci USA 72 (1975), 437.

4) Lieber, C.S., D.P. Jones, L.M. De Carli: Effects of prolonged ethanol intake: Production of fatty liver despite adequate diets. J. Chir. Invest. 44 (1965), 1009.

5) Péquignot, G.: Les problèmes nutritionnels de la société industrielle. Vie méd. Canad. franç. 3 (1974), 216.

6) Popper, H.: Pathologic aspects of cirrhosis. A review. Am. J. Path. 87 (1977), 288.

7) Thaler, H.: Zur oralen Behandlung der Fettleber init Leberextrakten. Ein kritischer Beitrag zur Frage der sogenannten Leberschutztherapie. Ther. Umschau 18 (1961), 134.

8) Thaler, H.: Leberbiopsie. Ein klinischer Atlas der Histopathologie. Springer, Berlin-Heidelberg-New York, 1060, p. 178.

9) Thaler, H.: Voraussetzungen für den alkoholischen Leberschaden. Therapiewoçhe 27 (1977), 6580 .

10) Van Waes, L., C.S. Lieber: Early perivenular sclerosis in alcoholic fatty liver: An index of progressive liver injury. Gastroenterology 73 (1977), 646 .

\section{司会のことば}

脂肪肝とは肝に脂肪が過剩に蓄積した状態で，主とし てトリグリセライドよりなる。

組織学的に，視野の50\%以上を脂肪滴が占める場合， 脂肪肝との診断がつけられることが多いが，これは湿重

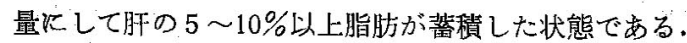

肝への脂肪の蓄積は（1）肝への脂肪の流入和よび肝 に和ける脂肪合成の面と，(2) 肝に拈ける脂肪の酸化 および肝よりの分泌の面とのバランスがくずれ，後者に 比し前者が優鐢となった結果拈こる。

この様な脂肪肝をおこす原因としては，肥满，糖尿 病, アルコール，薬物中毒: 内分泌翼常，低栄養などが あげられ，他に特殊型として妊娠にともならもの， Reye 
症候群などがある。

今回脂肪肝といら古くから問題となっているテーマを とりあげたのは，一つには最近の生化学的研究の進歩を 心秃，脂肪肝飞新しい観点から光をあててみようとし た訳であり，むら一つの目的としては，臨床的に血液生 化学的恰查から診断の手がかりとなるるのはないか，ま た慢性肝炎との鑑別上有用なるのは何かなどについて討 論していただきたかったからである。

まず脂肪肝の定義について病理学的立場から奥平氏に 話をしていただき，ついで，脂肪肝の成因についての考 察を，実験的研究から岡部氏に，臨床的面について武藤 氏にしていただくこととした。
臨床的に問題となるのは，脂肪肝と慢性肝炎の鑑別で あるが，診断面のポイントを，钣野氏括よび，杉本氏 に，臨床経過の面を传滕氏に打願いした．とくに脂肪肝 を示唆する肝機能検查，各種脂肪肝の鑑別おょび慢性肝 炎との鑑別に中心をしぼり，どの様な点に注目すればよ いか，新しい検查法はないか，生化学的変化をきたす組 織変化はどの位かなどについて解析を試みていただい た.

最後に，特別に参加していただいた Thaler 教授に， フルコール性肝硬変の発生病理について, 鄷富な経験に もとづく考察を批願いした。

\section{司会 葛西 洋一(北海道大学第 1 外科) \\ 杉浦 光雄 (㮌天堂大学外科)}

パネルディスカッション 肝臓をめぐる外科の諸問題

1.
慶応義塾大学外科
都築 俊治

食道静脈瘤 : 過去 8 年 10 ケ月の間仅㠷った食道静脈 瘤は90例である. 教室では下部食道を $10 \mathrm{~cm}$ devascularize す経胸的食道離断術之脾摘，胃上部周囲血行郭清 又は左胃静脈結紮切断を分割手術で行って来た。術後は 内視鏡検査によって食道静脈瘤の消長を钼察している が, 全例軽度の静脈瘤が再生していることが観察され たそとしてこのことは経胸的食道離断術のみの例とこれ に経腹操作を加えた例との間に差を認めなかった．最近 は細茎性ファイベースコープ GIF P 2 の出現によって 胃病変が把挃出来るようになったが，その結果治療を要 する高度の食道静脈瘤患者30例中10例に open ulcer, 20 例汇噴門静脈瘤，15例飞胃のびらんがみられ，食道静脈 瘤の々の费者は3例（10\%）に過ぎないことが判明し た.このことは胃病変を考えて食道静脈瘤患者を治療し なければならないことを示している。

肝門部癌：われわれは肝門部癌を肝管分岐部癌と肝臓 中央部にある肝癌が肝管へ浸潤したすのを包括する名称 であると考光ている，過去6年10ケ月の間に11例(肝管 分岐部癌10例，胆管細胞癌 1 例）に手術を行った。 入院 時総ビリルビンは5.6〜42.4mg\%を示したが，これを1.0
〜 13.5mg\%に減黄して手術を行った，術式別には右葉 切除 1 例, 左葉切除 10 例で, これに胆管切除, 胆道再建 を附加した．左葉切除10例のらち2 例には右肝動脈，門 脈右枝の切除，他の 2 例飞は門脈分忮部を広く切除し， 血行再建を行った，手術死亡はなく，全例が退院し得た が，遠隔成續をみると 2 年以内に癌死するるのが多く， この点について改良をはかる必要があると考光ている.

2.

筑波大学臨床医学系外科岩崎 洋治

3.
東京大学第 2 外科 二川 俊二

食道静脈癛 : 外科的治㞠の術式と適応：食道静脈瘤の 外科治療としては，門脈減压を目的とする血管吻合術と 䋛脈瘤汇直接侵警を加える直達手術とがあり，教室でる 種々の術式が試みられてきたが，血管吻合術は肝性脳症 の発生，吻合口の閉塞による再吐血などの術後合併症の ため，昭和39年よりは直達手術を採用してきた，昭和 42 年上りは開胸開腹による中下部食道・胃噴門部の広沉な 血行遮断を伴う食道離断術，いわゆる杲大第 2 外科法を 
施行してきて，満足すべき結果を得ている. 今回は，現 在の標準術式である食道離断術を中心に検討を加え報告 した.

教室で 経験した門脈圧え進症症例は，昭和24年以来 824例で, そのらち開胸開腹による食道離断術を施行し た症例は388例である. 手術時期别内訳では緊急手術例 69例，待期手術例223例，予防手術例96例となっている. 手術死は17例で，その死因では肝不全が 9 例之最む多く みられた，静脈瘤術後再破裂率は2.5\%であった．本術 式は，他の諸術式に比し最良の成績をみ，勧められる術 式であり，その適応は広く，年龄に制限なく，末期的肝 障害例以外々は適応となる。

肝門部癌：姑息的手術の術式選択：教室で経験した肝 外胆道癌は60例あり，そのうち肝門部癌は20例である. 切除例は 2 例，非切除例は18例で，切除率はきわめて悪 く, 非切除例18例中 4 例は試験開腹て残り14例に姑息的 手術が行われた．姑息的手術としては一側肝内胆管空腸 吻合を 4 例, 両側肝内胆管空腸吻合を 3 例, 左肝内胆管 空腸吻合十右肝内ステント插入術を 2 例, 両側肝内ステ ント择入術を 5 例に行った. 切除例はいずれる術後 11 ケ 月で癌再発死した. 姑息的手術での長期生存例は両側肝 内胆管空晹吻合例にみられ，20ケ月，12ケ月，8ヶ月生 存となっている. したがって姑息的手術としては本術式 が勧められる.

4. 北海道大学第 1 外科正置 明 食道静脈痹に関して：食道静哌瘤の手術的治療法に関 して教室例を中心に検索した結果を報告する.

対象は, 肝硬変, 特発性門脈圧六進症, 硬変合併肝癌 など72例で，このうち $81 \%$ に吐血歴があり， child 基準 ではAが50\%，Bが33\%， Cが17\%である.

外科治療として脾摘除，門脈減圧手術，食道離断， Hassab 手術および両者の合併など種々行なってきたが， 現在では食道下部和上び胃上部血行廓清と機械的食道離 断の併用を原則としている．食道離断は食道下部を約 $1 \mathrm{~cm}$ 切除後，機械的に再吻合する．この方法では術後 の再出血も少なく, 食道静脈瘤の完全消失も認められ, 良好な結果を得ている.

肝門部に関して : 胆道悪性疾患の治療は，他萑器癌子

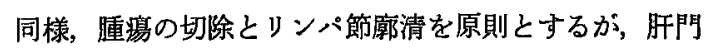
部癌は解剖学的関係や病巣の進展など手術適応の判定に 多くの問題がある.
教室の肝門部癌29例について，占居部位を手術適応か ら分類したところ，Bismuth の分類に左右両側肝管癌を 加え 4 型に分類するのが適当であると考えられたその 頻度は，I，II-L，IV型の順となっです，肺管浸潤 はIII, IV型に多く, 肝転移は $\mathrm{I}$ 型に多い。

これらに対し, 肝切除を含む肝門部切除, 肝内胆管架 腸吻合，腫瑒内插管拉よび外胆汁瘦などを行なった，成 績についてみると，姑息手術では予後不良であり，また 単なる肝門部切除では再発, 肝転移などの死亡例もみら れ，肝門部を含む肝切除が良好であった。

以上，肝門部癌をその腫瘍占居部位により 4 型に分類 したが，I 型は左右肝管の切除後に胆道再建を行ない， II , II およびIV型では脈管の 浸潤程度を加味した肝葉切 除，拡大右葉切除後温道再建を行ならのが適切である と考えます。

\section{5. 食道静脈瘤と肝門部癌の対策を中心として 順天堂大学消化器内科有山襄}

1. 経皮経肝的食道静脈㿈塞栓缸法：経皮経肝門脈造 影 (PTP) を応用した食道静脈瘤塞栓術を施行すれば, 食道静脈瘵破裂による出血を大きな侵襲を加えることな く，止血できる. 本法の適応は緊急出血例，および出血 の危険が大きいと思われる静脈瘫があり，手術を拒否し た患者または手術に対する poor risk 例である.

塞栓療法を14例の患者に施行した。塞栓物質として isobutyl 2-cyanoacrylate 使用した. 14例中 4 例は繋急 出血例で 2 例は止血することができたが，他の 2 例は短 胃静脈の塞栓だけで胃冠状静脈にカテーテルが挿入でき ず，数日後に再吐血がみられた. 本法の効果を期待する ためには静脈瘤に流入する短胃静脈と胃冠状静脈を全 部, 塞栓することが必要である. 塞栓後の 経過観察で は，1例は左胃動脈造影で静脈瘤の再開通がみられた。 内視鏡検查では静脈瘤が消失した例はないが，3例では 赤色の静脈瘤が白色になった。本法は姑息的な治療法で 另るが，祭急手術例を安全な待期手術例に変えることが できる。

2. 上部胆管程の診断 : PTC, ERCP, 血管造影の組 久合わせで83例の胆管癌の存在診断, 切除可否の決定が 全例飞できた，黄疸を伴う胆管癌には PTC ドレナージ を施行し，つぎに ERCP で逆行性に胆管を造影すれば 胆管の閉塞部位がはっきりする. 切除可否の決定には血 管造影が有効で，門脈特よび胆管動脈以外の動脈に变化 がなければ切除可能と診断できる. 主病巣から離れた位 
置にある粘膜内転移㧍よび壁内浸潤の診断には腢管二重 造影が有效である，胆管癌の診断は容易であるが，上部 胆管癌の切除率は $18 \%$ にすぎず，切除可能で予後のよい 上部胆管癌を如何に早期診断するかが 今後の問題であ る

6.

北海道大学第 2 外科磯松 俊夫

食道静脈瘤の外科治療として, 直達療法と選択的門脈 減圧術があるが，われわれは選択的門脈減圧として遠位 脾腎静脈吻合の成續について述へる，遠隔成續は，1 年 以上生存 $92.1 \%, 2$ 年以上生存 $89.0 \%, 3$ 年以上生存 $84.2 \%, 5$ 年以上生存 $66.0 \%$ であり, 社会復州率は 80.0 \%であった $(n=51)$. 肝性脳症は 5 例にみられた. 脳症発 生例は遠位側脾静脈一の脺静脈からの逆流がみられ，脾 静脈の膀から分離が重要と考えられた。術後脾腫は88.8 \%に縮小を認め, 脾機能光進もそれに応じた改善をみた (白血球 $\mathrm{p}<0.001$, 血小板 $\mathrm{p}<0.05$ ). 術後の食道静脈 瘤の消長を内視鏡的にみると, 出血の危険 Sign である RC Sign は術後早期に，かつ著明に消失する. その他の F因子，L因子などの改善は䡟進的である，小児を除い た耐術者49例について, 術後静脈瘤再出血は 3 例及られ たが，らち 2 例はわれわれの初期の症例で，吻合部血栓 によるものであった，食道静脈瘤以外の出血としては， 出血性胃炎 1 例，胃潰竅 2 例がみられたが，いずれも肝 硬变症例であり, 保存的治療により治ゆした

われわれが過去 8 年間飞治療を行った上部胆管癌は 35 例で, 根治手術が行われたもの 7 例 (20.0\%), 姑息手 術に和わったもの24例 $(68.5 \%)$ ，手術不能であったる の 4 例 (11.5\%) である. 手術死亡は根治手術で14.2 \%，姑息手術で16.6\%である，根治手術の遠隔成績は，
肝葉切除を含む肝門部腫淢切除は 1 例であるが, 術後 3 力月死亡. 肝門部腫鵿切除 5 例中 1 例が術後 1 年 6 力月 で死亡したが, 他の 4 例は, 最短 1 年, 最長 3 年経過し 現在生存中である.姑息手術としての肝内胆管空腸吻合 群では胆道感染を半数浮とめ，その平均生存期間は 2.6 月と短かく, 胆道感染をみないものの平均生存期 間は13.5カ月であった。

\section{〈特別発言〉}

北海道大学第 2 外科

杉汀。三郎

\section{司会者のまとめ}

食道静脈瘤については，緊急手術はさけて可及的に待 期手術にもちこむ，緊急手術術式としては食道離断術を 選択, 食道離断術では胸䶼内食道の血行遮断の重要性が 强調され, Selective shunt は経過追究の必要があり, 内 視鏡的硬化剂注入は経過追究が必要で, 硬化剤注入は静 脈瘤内に行らべき，PTPEは緊急症例を待期手術にもち こみらるが，永久效果は疑わしい，という討諭経過であ る.

肝門部癌については，根治手術は長期生存が得られる のは当然だが，姑息手術例です 2 年前後の生存例があ る. 根治手術と思った症例でる現状では必ずしも好成績 が得られるとは限らないが, 将来的には根治手術可能例 には積極的に肝葉切除を合併する根治手術を行ならべ き.さらに成績向上への努力として抗癌剤や放射線治療 の併用む考慮される. 早期診断は重要であるが，同時に 多中心性発癌や，skip lesionの見逃しのない診断法に ついて討論された.

\section{一 般 演 題}

1. B 型劇症肝炎の回復期に, 非 $\mathbf{B}$ 型と思われ る急性肝资を併発した一症例

東京医科歯科大学第 2 内科 小山 恒，入江 徽也，小沢 潔 大宮司有一，杉浦 克明，西村 正信 末永 松彦, 運村 靖, 武内重五郎

症例 : 21 嵅，女性。昭和53年 9 月 7 日黄㾇と意識障害
を主訴として 当科に転院した．入院時，肫性昏睡（IV 度), HBsAg (+), HBc 抗体 $2^{\circ}$ (IAHA 法), SGPT 2,630 単位, T. Bil. $11.2 \mathrm{mg} / \mathrm{d} l$, トロンボテスト $23 \%$, 脳波にて著明な徐波を又とめ, B 型劇症肝炎と診断し た. 血中 HBsAg-Ab 免疫複合体 $(+)$. Hemoperfusion などの治療により意識の正常化が，10月上旬には肝機能 の正常化が得られた。 しかし，10月19日に SGPT が再 
上昇し，黄疸の出現も認めた，後者は，HBs Ag 陰性化 を伴ったこと，血中免疫複合体（十）であるが，血中 HBsAg-Ab 免疫複合体 (一) であったことから, 激症肝 炎の沿潦の際に行なった輸血による非 B 型急性肝炎（潜 伏期約40日）の做発と考光られた。

\section{2. 今春多発した Non B 急性肝炎の検討}

関東派信病院消化器内科

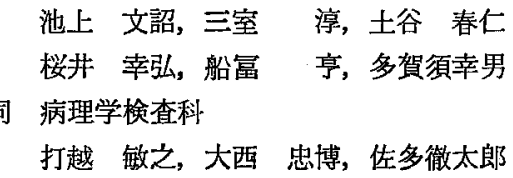

本年 1 月より 7 月末までに当科には，輸血特よび薬策 飞起因するもの除き，病初期より経過钼察が可能で, 組織学的にも確猃しえた急性肝炎が31例入院した。これ は例年の 3 倍以上であった。注とんどが散発例であった が，東京を中心に流行の存在が推定された．HBs 抗原， HBc 抗体, HA 抗体の pair 血清に上る測定の結果, 確 認できたものはA型10例，非 A非 B型10例，B型 7 例で あった. 臨床症状としては，A型で全例に発熱と黄疾， 非A 非B 型は発熱・黄疸に下㢉を伴なら例が多かった。 肝機能検查では A 型に膠質反応と IgM の高值が認めら れた，予後はA型，B型は全例良好であったのに対 L て，非 $\mathrm{A}$ 非 $\mathrm{B}$ 型は遷延，再燃するものがあり，慢性肝炎 への移行が示唆され，今後の経過が注目された。

3. $\gamma$ GTP が低值を呈した急性胆汁うっ滞性ウ イルス性肝炎の 2 例

東京大学第 3 内科

佐藤 弘，池淵 研二，岩崎 泰彦

井䞤 道夫，北村 達也，板倉 弘重 大久保昭行，大沢 仲昭，小坂 樹徳

症例 130 歳占. 腹痛, 食欲不振で発症. 9 日後入 院. 入院時 GPT 3232U/l Al-p 253U/l, $\gamma$ GTP 356U $/ l$ T.Bil. 9.3mg/dl，入院後 T.Bil. は最高 35.6 (D. Bil. 28.0）と上昇したが $\gamma$ GTP は12以下と低下した。 この 時 Al-p 182, GPT 129，肝生検では著明な䏣汁らっ湍が みられた。症例 2 29藏合， 1 年前肝機能正常, HBs 抗 原 $(-)$ 全身僚急感にて発症, 約 1 週間後 GPT 1425, T. Bil. 4.7 Al-p $178 \gamma$ GTP $187 \mathrm{HBs}$ 抗原 $(+)$. 更比 2 週間後 T.Bil. 23.5 (D. Bil. 21.0) $\gamma$ GTP 20 Al-p 161 GPT 1310であった。赭症例ともBil と $\gamma$ GTP は相反
的炕変動し Al-p 上昇は軽度だった，症例 2 で血清総エ ストロシェンは病初 $170 \mathrm{pg} / \mathrm{m} l$ 黄㡺極期 140 ，回復期 120 〜140であった。

\section{4. 比較的症状の軽度な bridging necrosis を} 伴う肝炎の臨床的検討

新潟大学第 3 内科 坂口 正剛, 市田 文弘

富山医科菜科大学第 3 内科佐々木 博

Bridging necrosis を主体とする䀒炎61例につき臨床的 検討を行なった.

自覚症状については，無症状のるの 4 例，極軽度の症 状のむの 1 例, 肝以外の合併症症状の及のもの 4 例と, 計 9 例ではいわゆる肝炎様定状は認められなかった。 なお 自覚症の有無と肝機能とは特に一定の関係はなかった。

Bridging necrosis 全例についての HBs 抗原陽性率 みると男性63\%，女性35\%であり，男性ではB 型肝炎ウ イルス，女性ではそれ以外の要因に上り bridging necrosis が生ずる可能性があることが示唆された。 また， HBs 抗原の家族内集積家系が比較的多かった.

組織学的に経過の追えた bridging necrosis 17 例のう ち，少くとも6 例は肝硬变へ進展して抢り，内 3 例肝 細胞癌が発生した.

\section{B 型慢性活動性肝炎より 肝腎症候群を 呈し} て死亡した免疫不全の 1 症例

東京慈恵会医科大学第 1 内科 木村 和夫，藤沢 洌，亀田 治男 社保大宮病院内科伎田跻

24歳，男性，乳幼览期上り多彩な細菌感染症に反復䍜 患し, 昭和44年 4 月生検にて HBs 抗原陽性慢性活動性 肝炎之診断され，1 年後組織学的飞 肝硬変が 確認され た. BSP (45分) 20\%，rーグロブリンは 5〜6\%と低 い. 血液型は $\mathrm{A}_{1}$ にて同種血球凝集素を欠き，家族歴， 既往歴から Bruton 型伴性低 $\gamma$-gl 血症基磷疾患 し，CH から LC へ移行したと考党られた。昭和54年 4 月，発熱とともに黄疸，腹水が出現，非代償性 LC と診断された．血浆総蛋白 $4.2 \mathrm{~g} / \mathrm{dl} ， \gamma-\mathrm{gl} 1.5 \%$ でり， IgG $210 ， \mathrm{~A} 30 ， \mathrm{M} 50 \mathrm{mg} / \mathrm{d} l$ で， T 細胞 B 細胞数は正常 だか，血清補体洒は低值を示し，腹水は一時消失するる 以後利尿剤に反応せず，2 力月後肝腎症候群にて死亡. 免疫不全と肝疾患について與味ある自験例につき報告し た. 


\section{座長まとめ $(1 \sim 5)$}

関東莪信病院消化器内科池上 文詔

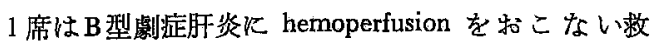
命し，回復期飞非 $B$ 型肝炎を併発した貴重な症例で，病 初期炕認められた HBs-Ag-Ab 免疫複合体化つき，Raji 細胞を用いた杉浦らの方法であるが附議された，2席は 今春東京地方飞発熱・下浰・黄誼を特徽とする急性肝炎 が流行した可能性についての発表であった，しかし他施 設からの追加はなかった。 3 席は胆汁らっ淃型肝炎の経 過中に TBil とrGTP が reciprocal K変動した 2 症例 につき，原因として女性ホルモンの関与が推定されると の報告であった，第 4 席は bridging necrosis を伴なう 肝炎が劇症肝炎のような one time attack 火上る場合と HBs-Ag carrier 飞みられるような自覚症状を欠く場合と があるとの発表に対し，両者間に組織学的な差の有無に ついて，今後の検討を求める質問があった。第 5 席は先 天性免疫不全例に $\mathrm{B}$ 型肝炎が合併し, 肝硬变一移行, 肝 腎症候群にて死亡：細胞性免疫能低下との関連 飞おい て,ッ反陰性の結果が注目され附議された。

\section{6. 特異な経過をとった劇症肝炎の 1 例} 立川綜合病院 内科 村山 久夫, 土田 秀夫, 味方 正俊 杉本 伸彦, 斉藤 古志, 立川 信三 症例は30歳男性，黄疸で発症，肝萎縮が著明となり， CT スキャンで結節形成と肝中央部に low density 部が 認められた. 非 A 非B型劇症肝炎としてステロイド剤, グルカゴン・インシュリン投与行うむ血清ビリルビンは $43.9 \mathrm{mg} / \mathrm{d} l$ 飞達し, 皮膚に黑褐色の色素沈着を認め䀒不 全の為, 全経過約 4 ヶ月で死亡. 肝は重量 $1,315 \mathrm{~g}$ で肉 眼的に比較的大きな結節形成がみられた，組織学的には 一部で再生像をみるが結節形成は不完全で結節周团飞著 明な胆栓形成がみられた。大部分は出血で占められこの 部に偽胆管形成を認め，好銀線維は比較的良く保たれて いたが，肝細胞は消失していた．膠原線維の沈着は比較 的少く，再生と壊死が綝返していたものと考えられた。 皮首は不全角化とメラニンの增加がみられた。

\section{7. 劇症肝炎の一症例}

防衛医科大学校第 2 内科

藤倉 覚, 日野 邦彦, 富田 純子

横井真理子，宮川浩，宮原透

桑原 龍雄，田中 基樹，剛崎 睦也

岡田 昌之，岩㥓 政明，高橋 淳

症例は，62歳男性，昭和 54 年 6 月下旬より全身倦急感 が出現し， 7 月下旬, 黄疸が発来した為, 急性肝炎の晾 断で近医顷入院，加療を受けていたが，2病週頃より， 腹水が出現, 3 病週より，意諳障害が現われた為，当院に 入院，臨床症状ならびに白血球增多，Prothorombin 時 間の延長，高 Bilirubin 血症などから亜急性肝炎と診 断し, 直ちに交换輸血療法, プレドニンの大量療法を行な い，一時，意識状態は改善したが，その後，高 Amylase 血症，Transaminase の急上昇，督不全が合併して死亡 した，病理組織学的には，肝は，业広範性壊死を認め， 膵には，米粒大〜拇指頭大の壞死が多発していた。

\section{8. 抗 $\mathbf{H B c}$ 抗体陽性血輸血後に起った B 型激 症肝炎の一例 虎の門病院消化器内科 \\ 蝶名林直彦，三浦 雅弘 竹内 和男, 中島 正男

同 病理学科遠藤 雄三

症例. 47 歳，男. 昭和53年 7 月近医で胃癌と診断され 8 月 1 日当院外科入入院. 入院時, 活動性肺結核見出 だされ，抗結核療法開始. 8 月 8 日胃亜全剔施行. 術前 術後保保存血，1,800cc 輸血したが,11月12日発熱, 黄疸 を伴い肝炎を発症。発症時，HBs 抗原抗体之陽性， GOT 2,800, T-Bil. 8.3g/dl，はぱたき振戦 $(+)$, 軽度 意識障害 $(+)$, 輸血後 $\mathrm{B}$ 型激症肝炎と診断, 諸種治療 に上り，次第に回復，発症後90日目に肝生検を行い，急 性ウイルス性肝炎回復期像に一致する所見を得た．当症 例では，輸血血液の検索の結果，HBs 抗原はすべて陰 性で岁ったが, Anti-HBc 価が $2^{10}$ を示す血液があり， 今後 B 型輸血後肝炎の予防対策上, Anti-HBc の検索の 必要性が感じられる。 
9. 夫婦間感染により発症したと思われる HBs Ag 陽性劇症肝炎の一例

東京齿科大学市川病院内科

川村 顕, 鈴木 弘造
慶応義熟大学消化器内科
織田
正也, 渡辺 伤史, 中村 正彦
永田 博司, 土屋 雅春

症例は23歳男性. 本症例の妻方昭和53年 2 月 22 日子宮 外妊娠手術の際 $2,600 \mathrm{~m} l$ の輸血を受け 2 週間後退院し 夫と 同居. 同年 4 月 24 日発黄 と HBs Ag 強陽性の 輸血 後肝炎之診断され再入院. 経過良好で 6 月 8 日 HBsAg 陰性化す。 夫は同年 7 月 11 日抜歯を 契機に高熱，悪心 出現，同月14日黄疸指摘され入院， $\mathrm{HBsAg}$ 陽性，血清 GOT, LDH が異常高值. 17日肝性脳症出現し，20日よ り昏睡に陥った。しかし，交換輸血により回復し，直ち に HBsAg 陰性化，発症後約 6 ケ月後に HBsAb か陽性 化す．発症 3 ケ月及び 1 年 3 ケ月後の腹腔鏡検査では, いずれも肝表面には明らかな湾痕化像は認められず，組 織学的には, 前者では急性肝炎，後者では chronic inactive hepatitis の像を呈した。

\section{座長まとめ $(6 \sim 9)$}

$$
\text { 虎の門病院消化器科 }
$$

6 席は亜急性肝炎の経過を示しながら，劇症肝资に相 当する病理所見で生前 CT .上結節形成とともに膵腫大 がみられたとの発表で, 脺腫大について，質問があった。

7 席は，劇症肝炎では互急性型の経過を示した報告だ が，その病理組織に関して質疑発言がもたれた。

8 席は抗 $\mathrm{HBc}$ 抗体陽性血，輸血後㲹起った B 型，劇 症肝炎の報告で，保存的療法で救命したが，輸血血液の 抗 HBc 抗体の検索が必要になるが，具体的には困難な 問題であらう。

9 席は，HBs 抗原陽性の翰血後肝炎の 妻から感染し た夫が劇症肝炎を発症したか，交换輸血により救命乙得 た報告で，発症 3 ヶ月後の組織像は，急性肝炎の回復期 であった，との貴重な症例の発表であった。

\section{5 種薬剤に感受性を示した 1 症例の検討 東京透信病院消化器科 \\ 橋本 英明，土㭑 優子，福田 龍子 \\ 藤樹 敏雄, 高橋 一江, 兼高 羍式 \\ 藤原 郁夫}

RA の治療目的で投与されたアスピリン，アルクロフ
ェナック，SB-PC により発疹，インドメサシンにより 肝障害, メフェナム酸によりシェーダレン症状が各々出 現した 1 症例について検討した. インドメサシンに対し リンパ球刺激試験を施行し陽性であった。経過中 IgA， IgM が低值を示し，T cell 56\%，B Cell 8.6\%で B Cell の減少が認められた，好酸球は常に1\%前後であ った. Prostaglandine は T Cell にも関与しているとい われており，構造の異る 5 種薬剤炕対する副作用の出現 はRA を基礎とした免疫不全と非ステロイド系消炎鎮 痛剂による Prostaglandine 合成阻害が関連したためと 思われた.なおこの症例は ARA の診断基準を充してい たが，rーグロブリン值は $1.5 \mathrm{~g}$ 以下でありRA 反応は常 に陰性であった。

\section{1. 塩酸ヒドララジン 長期服用による 肝障害 の一症例 \\ 埼玉医科大学第 3 内科 \\ 山羽 義貴, 宮沢美智子, 一戸 彰 塚田 悦男, 伊藤 進}

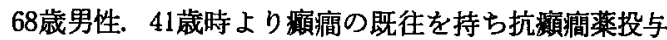
中，65歳時より高血圧の為塩酸ヒドララシンン 75 ～150 $\mathrm{mg}$ ）服用. 昭和54年 3 月 10 日腹痛を訴立入院. 発熱, 黄疸，軽度意識障害があり，表面平滑辺縁鈍な肝を右季 助下に 3 横指触知した。白血球 $17,600 \mathrm{~mm}^{9}$ ，好酸球 0 $\%$, GOT. GPT 共 $300<\mathrm{mu} / \mathrm{ml}, \mathrm{LDH} 600<\mathrm{mu} / \mathrm{ml}, \mathrm{Al}-\mathrm{P}$ $297 \mathrm{mu} / \mathrm{m} l$ T. Bil $8.1 \mathrm{mg} / \mathrm{d} l$ アンモニア $105 \mu \mathrm{g} / \mathrm{d} l \quad \gamma$-GTP $41 \mathrm{lmu} / \mathrm{m} l$ と肝機能障害を認めた。 入院後全ての投薬を 中止したところ 4 日後意識清明となり，4月７日肝機能 検查は正常となった，生検像で帯状の壊死を認め薬㓣性 肝障害が疑われた，塩酸ヒドララジン再投与後，肝機能 の再上昇を認めた． 報告の極て稀な，長期の薬剤投与に よる肝細胞障害型肝炎を呈した症例を報告した。

12. グリチルリチン製剂の長期大量投与によ り偽性アルドステロン症を呈した慢性肝炎の 1 例

新潟大学第 3 内科

尾崎 俊彦, 本間 明, 渡辺 省三

上村 朝輝，鈴木 司郎，市田 文弘

症例は34歳男性で, 昭和53年 6 月食欲不振，全身惓怠感 出現し，某病院で急性肝焱の診断にて加療を受け症状軽 快するも，昭和54年 1 月感冒様症状と共に肝機能の増覀 
を認め再入院となる.グリチルリチン（経口剂：273mg， 静注 : $80 \mathrm{mg}$ ）計 $353 \mathrm{mg} / \mathrm{day}$ を 3 ケ月間投与され高血压 症, 低K血症出現し, 肝機能異常々頭重感持続するため 精査の目的で同年 5 月当科入院した. 入院時肝脾嗹と低 K血症を伴ら高血圧症を認めたが，食塩制限とグリチル リチン製剤の投薬を中止して経過観察したところ，血清 K值と血圧の正常化を認め，グリチルリチンによる偽性 アルドステロン症と考克られた。 な和本症例は HBs Ag

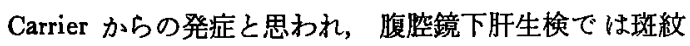
肝, CAH with bridging necrosis の所見を呈し，ステ ロイドの漸減投与により諸症状の改善を認めた.

\section{3. アルコール性肝咨の一考察}

聖マリフンナ医科大学第 2 内科

河野 誠, 志沢 喜久 渡辺勇四郎，岡部 和彦

同 中央電影室 及川三千雄

症例は37歳主婦. 领酒歷 2 年, エタノール攝取総量約 94kg，食事は朝昼は貧弱であるが，夕は普通ないしそれ 以上摄取。本年 2 月下旬, 著明な肝脾腫, 黄疸のため某 院へ入院. 約 1 ケ後当科入転院した。当科入院直後 （4月 7 日）の第 1 回肝生検像は典型的フルコール性肝 炎 (pericellular fibrosis, 多核白血球の浸潤，アルュー ル硝子体)で施った．その約 1 ケ月後 (5月 2 日) の第 2 回肝生湌では肝細胞の再生像が 目立ち,ささらに1.5ケ 月後（6月18日）の第 3 回腹腔鏡下肝生検では肝表面は 細顆粒状で，組織学上 micronodular cirrhosis の像を呈 した. まとめ: 従来言われるアルコール長期, 多飲者で なくわずか 2 年, エタノール総摄取量約 $94 \mathrm{~kg}$ の 领酒歴 飞も拘わらす，アルコール硝子体を認める典型的アルコ 一ル性肝炎を発症し，わずか 4 ケ月で硬変化の組織像が 得られた 1 例を提示した。

14. 亜広籍性肝細胞埭死を 呈し，死亡したア ルコール性肝硬変の 1 症例

北海道勤労者医療協会内科

田辺 利男, 羽二生輝樹, 美馬 聘昭

旭川医科大学第 3 内科

関谷 千尋

症例住49藏，男性，フルコール多飲者. 腹望鏡検查， 肝生倹にて昭和48年に小葉改築を伴わないアルコール性 肝障害でしたが，昭和51年にはアルコール性肝硬変へと 進展していた。経過 HBs 抗原，抗体， $\mathrm{HBc}$ 抗体山共に 陰性でした．52年 7 月，9月の 2 回にわたり食道静脈瘤
の破裂を叔こし，計 $3,600 \mathrm{~m} l$ の輸血を受けた．同年11月 飞始めて HBs 抗原が陽性となり, 同年12月飞急性 B 型 肝炎の発症をみ，肝不全にて死亡した。剖倹で，肝は $745 \mathrm{~g}$ と萎縮し，肉服的には肝表面は微細顆粒状の結節 を呈した，組織では亜広範性肝細胞壊死の像を示した。

\section{5. 多量领酒患者にみられた 全身性 ヘモジデ リン沈着症の 2 例 \\ 三宿病院内科 \\ 太田 裕彦 (現東大第 1 内科) \\ 池田 知純, 佐藤源一郎, 佐藤 亮五 上野 幸久 \\ 同検查科 \\ 遠藤了一 \\ 同 病理 \\ 馬淵 基樹}

第 1 例は47歳の男性で約10年間每日日本酒 1 升领んで いた. 5 年前糖䐂病と診断されていたが，今回，発熱， 左上腹部痛を主訴として入院，第14病日，左横隔膜下膿 瘍で死亡した．第 2 例は46歳の男性で約 20 年間，毎日日 本酒 1 升飲んでいた. 今回, 黄嗵を主訴として入院し, 5 ケ月後肝不全にて死亡した．両例とも解剖では，著明 なへモジデリン沈着を伴なった肝硬変の他に，膵蔵など 他臟器にもーモジデリン沈着が見られた。.各々の肝硬変 の形態像は多少異なるものの, 雨例とも全身性のへモジ デリン沈着の原因として，長期にわたる多量の领酒が関 与しているものと考穴られた。

\section{座長まとめ $(10 \sim 15)$}

埼玉医科大学第 3 内科伊藤 進

演題10〜15は薬物アルコールによる肺障害にかんする ものであった１0）はインドメサンン障害例で，他の種 々の薬剤です薬疹を呈した，薬疹と肝障害との発生の差 を考えさせるものであった.11)は塩酸ヒドララジン長期 服用による例で，チャレンジテスト陽性，本薬物例は報 告のな招少く，3年といら長期の点も興味あるものであ った．12）はグリチルリチン過剩投与による偽アルドス テロン症の報告で，三辺元教授より投与量，作用機構に つき発言があった，13）では,アルュール性肝炎から硬 変化について，時期の短い点, アルコール量などにつき 質疑があった，当初の組織侵襲の強さが影響するものと 考学られた. 14)はアルコール性障害にウイルス性肝炎 が加わり，亜広沉性㯰死をきたしたことに質疑があった がそその間领用はないことがただされた．15）は，著明 
な肝へモジデローシス2例を示し，アルコール多量飲用 に関連を求めたものであった。

16. 特異な病理所見を呈しウイルス粒子を検 出しえた cytomegalovirus (CMV) hepatitis 1 例

日本大学第 1 病理 柄沢 勉, 志力 俊夫 ヒトの CMV 感染症の型は多様であり，それに伴う 肝病変む多種多様で, かつ非特異的なるのが多い，CMV に特有な封入体を肝細胞にみる事が稀であるからであ る.さらに肝細胞にウイルス粒子をみたという報告も無 い. 我々は67歳女性で Immunoblastic lymphadenopathy のために抗腫湯凮の投与をらけた剖検例で，全身性 CMV 感染症をみたが， とくに肝缄に小指頭大の CMV によるよく限局した肝壊死巣をみた．その極く周辺部の 肝細胞に特ちょう的な核内封入休をみたが，他の部分で は，炎症像は全く無く，また CMV infection の evidence も無かった。このような病理所見は特異で，種々 系唆の多いところである.ささらに電顕的にウイルス粒子 を多数核内に，稀に細胞質内に見出したので報告する。

\section{7. 肝細胞質内好酸性小球体を呈した asym- ptomatic PBC の一例}

横頁賀共清病院内科

坂本 龍, 小泉 精策, 金山 正明

症例：72歳女性，生来健康で気管支炎症状で来院の際 al-p 高值の肝機能異常が偶然発見され入院精查. 肝脾 腫や黄庭なし. 検查所見 : GOT 78, GPT 43, al-p 48.7 K.A 単位, 総ビ $0.6 \mathrm{mg} / \mathrm{d} l$. T.P $8.0 \mathrm{gr} / \mathrm{d} l(\gamma-\mathrm{gl} .29 .3 \%)$, IgM $363 \mathrm{mg} / \mathrm{d} l$, 抗 mitochondria 抗体陽性, 血沈 $72 \mathrm{~mm} / \mathrm{h}$. DIC にて肝外閉塞なし，肝針生検にて florid duct lesion を伴うグ鞘炎あり， stage II (Scheuer) に相当する PBC. 肝細胞には小葉内均等分布の好酸性小球体あり, PAS, Orcein 銅各染色は陰性. 電顕にて，小球体は多樣で, rough ER 内にあるもの，限界膜のないるのがあり内容 は electron lucent haloに囲まれて microfibrilar core なしているものが多い. 考案：PBCに拉いて銅蛋白沈 着中 alcoholic hyaline が報告されているが，その他の 蛋白細胞内移送障害の可能性を示唆する一例と考える.
18． 再生不良性貫血を 合併した 慢性肝炎のー 例

\begin{tabular}{|c|c|c|c|c|c|c|}
\hline & 田中 & 直䇦, & 北條 & 一夫, & 佐々 & 下良美 \\
\hline & 桑名 & 斉, & 渡辺 & 幸一， & 荒川 & 泰行 \\
\hline & 長谷 & 克, & 本田 & 利男 & & \\
\hline 同 & 病理 & & 小林 & 楨雄, & 柄沢 & 勉 \\
\hline & & & 桜讲 & 勇, & 志方 & 优土 \\
\hline
\end{tabular}

症例は32歳女性. 昭和53年10月全身隐意, 悪心などを 主訴として入院. 肝缄は 2 横指触知するす, 全身のリン パ腺腫脹や脾腫は認めず. トランスアミナービと胆管系 醭素の軽度ないし中等度の上昇がみられたが，HBs 抗 原・抗体，抗核抗体， RA, LE 細胞，クームス試験など はいずれる陰性であった，肝生検で慢性肝炎非活動性の 所見が得られた。一方入院時, WBC $5,300 / \mathrm{mm}^{3}, \mathrm{RBC}$ 374 万 $/ \mathrm{mm}^{3}$, Hb $11.3 \mathrm{~g} / \mathrm{dl}$, Ht $34.1 \%$, Thrombocyte 33.2 万 $/ \mathrm{mm}^{3}$, Roticulocyte 26\%であったが，12月末頃よ り末梢血では沉血球減少が目立ち始め, $39^{\circ} \mathrm{C}$ 発熱と出 血性素因が増強した. 生検ならびに剖検の骨䯣は, 再生 不良性䆩血に相当する所見であった。

\section{9.ルポイド肝资の一症例}

防衛医科大学校第 2 内科

$\begin{array}{lrcr}\text { 宮原 } & \text { 透, 日野 } & \text { 邦彦, 宮川 浩 } \\ \text { 藤倉 } & \text { 覚, 広木 } & \text { 忠和, 岡崎 } & \text { 睦也 } \\ \text { 岩崎 } & \text { 政明, 高橋 } & \text { 淳 } & \end{array}$

症例は60歳女子, S.53年 8 月黄疸, 関節痛で発症, 急 性肝炎の診断で入院. 同年10月，transaminase 下降する も, 黄㾝の増強, 腹水が出現し, 同時に RA, LE 細 胞，抗核抗体が陽性を呈した.ルポイド肝炎の㟝断の もとにプレドニンの投与を開始したところ, 臨床症状は 改善し自己抗体も陰性化した．S. 53年 4 月，再び関節 痛が出現, 各種自己抗体も陽性となり入院となる.入院 後, 腹腔鏡, 肝生検で, 形質細胞浸潤など多彩な像を呈 する肝硬变症と診断した，本院の各種肝疾患134例につ いて, 赤沈, RA, LE 細胞, 各種自己抗体, $\gamma$-gl., なと の項目別に陽性率を検討した. その結果，亜急性肝炎， 慢性活動性肝炎, 肝硬変症などに高い陽性率を示したの で併せ報告した. 


\section{0. 小児急性肝炎の臨床病理学的検討}

金沢大学第 1 内科

杉本 立甫，鈴木 邦彦，西邨 辟吾 加登 康洋, 小林 健一, 服部 信

当科で経験した例の小児の急性肝炎について臨床病理 学的検討を和こなった. 年秢分布は $6 \sim 13$ 歳で，男 3 例，女 2 例である. 初発症状として発熱㹥 5 例中 4 例， 黄疸は 5 例中 4 例飞認めた. HBsAg は 1 例に陽性であ った. 肝組織像では 5 例中 3 例が急性肝炎, 1 例は持続 性肝炎，1 例は亜広沉性肝壊死を示した。予後では 4 例 は肝機能検查は改善した，亜広沉性肝壊死を示した 1 例は発病 9 力月で死亡した，亜広沉性肝壊死を示した HBsAg陰性の 1 例は 8 藏の男子で上気道炎権患時に肝機 能異常を指摘され当科入院. 症状は一時軽快したが発病 約 8 力月目に発黄, 意識障害を認め再入院. 頻回の交換 輸血にもかかわらず死亡した．小児の急性肝炎は比較的 予後はよいと思われるが，死亡例も経験したので報告す る.

\section{Vertical transmission による急性 B 型 肝炎の検討}

東京大学小児科

白木 和夫, 桜井 迪朗, 衛藤 隆
同 翰血部
同 産婦人科
吉な2子
川名 尚

我々は HBs 抗原キャリアーから生れた児60例の長期 追跡調查を続けて和り，内13例 (22\%) が HBs 抗原持 続陽性化したが，この他飞急性 B型肝炎 3 例 (5\%) が 見られた.この内 2 例の母は $\mathrm{HBe}$ 抗体陽性， 1 例の母 は HBe 抗原抗体とも陰性であった. いずれも無黄疸で， GOT, GPT の上昇は生後 3 力月で見られ，慢性肝炎症例 より早い傾向がみとめられた，1例で $\mathrm{HBe}$ 抗原 $\rightarrow \mathrm{HBe}$ 抗体の seroconversion が確認できた。

結論 : HBe 抗体陽性の母からも児への 垂直感染が起 る.ただしこの場合には児がキャリアー化することは無 いか，急性肝炎を発症することがある. 従って母が HBs 抗原キャリアーである場合，HBe 抗体陽性であっても 児が全く安全とは言光ず，出生後少なくとも半年間は十 分な観察下に置くべきであると考えられる。
22. Gianotti 病の 6 例の臨床的検討一特に 非 典型的経過をたどった症例を中心に

$$
\begin{aligned}
& \text { 東京逓信病院小坚科衛藤隆 } \\
& \text { 東京大学小児科 桜井 迪朗, 白木 和夫 } \\
& \text { 東京大学輸血部吉原なみ子 }
\end{aligned}
$$

最近 5 年間に経験した Gianotti 病 6 例を報告する. 発症年路は11ヶ月〜 1歳 8 ケ月（平均 1 歳 4 ケ月）であ り，皮疹の出現期間は16〜40日間 (平均28日間)であ った. subtype は adw 1 例，adr 3 例，ayw 1 例であ $\eta$, 感染経路は 5 例が母親以外の同居家族からの水平感 染であったが， 1 例の母親は e 抗原陽性のキャリャー であらた，GOT，GPT は全例で上昇したが，2例では その程度は正常上限をわずか越える程度の軽いるので 更った. 6 例中 5 例が HBs 抗原持続陽性 (内 3 例で肝 生検：CIH 2 例，NSRH 1 例) となり，他の 1 例怯皮 疹出現後 9 ヶ月で HBs 抗原は陰性化し，12ヶ月より HBs 抗体が出現した.

\section{3. 新生児及び小児へルペス肝炎の検討 日本大学病理阿部 蜸治, 内田 俊和 山田 勉，志方 俊夫}

全身性ヘルペスウイルス感染症に上り死亡した新生児 3 例，小児 1 例及び興味ある知見を得た成人 1 例につい て特に病理所見について報告する。新生児では臨床的に は発熱, 呕吐，出血㑯向などが共通所見で，肝はいずれも 腫大し，白色小罗死巣をビマン性に認めた。肝細胞核内 には cowdly A 型及び B 型封入体を認め, 電顕的にも ウイルス粒子が認められた，小児例( 9 歳，男児)では肝 細胞核内以外飞細胞質にもウイルス封入体を認めた。本 症例では病理学的に免疫不全症が疑われた，成人（39 歳，女）は悪性りンパ重治療のため抗癌阂投与を受けて いる最中に Herpeszoster にかかり死亡した例で，肝細 胞には封入体を認められないにも拘らず電顕的にウイル ス粒子を認めた．いずれの例でる壊死巣及び門脈域に於 ける細胞浸潤は軽微で，副腎には出血，壊死巣に加兄封 入体を認めた.

\section{4. 小児の肝疾患一生検症例の検討} 埼玉医科大学第 3 内科

一戸 彰, 塚田 悦男, 伊藤 進 小児の肝疾患に打いて肝生検を行ならには制約があり 困難な事が多い，われわれ恃過去20年間に 約 6,000例の 
肝生榆を行っている。.このらち15歳未満の肝疾患症例は 44例で，このらち生検は37例，試験開腹によ万るの 4 例，剖検 3 例であった．幼児では著明な肝腫大を主訴と 乙て来院. Reye 症候群, 先天性肝線維症, 糖原病など の代謝疾患が多く，児童では全身聪怠感，黄瘨を主訴と ， 慢性肝炎 7 例，肝硬变 7 例，脂肪肝 4 例，球状赤血 球症 3 例，体質性黄疾 2 例などであった。慢性肝炎で 2 例，肝硬変 3 例飞 HBsAg が陽性を示し，HBsAg 検査 以前の症例のうち肝硬変の 1 例にオルセイン染色陽性例 がみられた，最近では肥満児が多く，脂肪肝の增加む考 学られ，また HBsAg 陽性者の発見される機会も多くな ってきて扣り肝生検による組織診断が必要と考兄る。

25. 幼若乳児に発症する一過性の高度な 出血 傾向を示した肝障害の 4 症例

$$
\text { 東京大学小児科桜井 迪朗 }
$$

母乳栄養児に発生する，特異な，肝炎と思われる肝障 害で，ビタミンK矢性の重篤な出血傾向を示寸症例 4

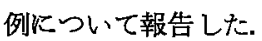

出血傾向は一過性で，ビタミンK投与，及び輸血によ く反応し，その後再発することはなかった。

肝障害は，まず一過性の閉塞型高ビリルビン血症を認 めたあと，数日から20日ほど遅机て，逸脱醉素值が極大 に達し，長期に遷延するすのるあるが，組織学的な変化 は俥微である.この原因あるいは病原体は不明であるが IgM 值の上昇を認めることと, 発症時期が夏季に集中 していること，便性異常を諰めるるのがあることから， ウイルスによる可能性が考兄られ，末知の病原体と思わ れた。

新生児肝炎との相異点についてもられた。

\section{6. 肝内胆管の完全欠損した一剖検例} 長崎大学熱帯医学研究所病理

$\begin{array}{lrrrr} & & \text { 寺尾 } & \text { 英夫, 板倉 } & \text { 英世 } \\ \text { 同 原研病理 } & & \text { 関根 } & \text { - - 郎 } \\ \text { 同 小児科 } & & \text { 松田 } & \text { 静宗 }\end{array}$

Ahrens ら（1951年）の報告以来，盰内胆管閉鎖症は 注目されているが症例数も少なくその本態は明確化され ていない，我々は本症の肝の組織学的変化を肝外胆道閉 鎖症と比較検討し，本態・病熊について考察した.

症例： 1 歳 7 ケ・女児, 生後 3 日目より黄疸が出現 し死亡まで持続. 77 日目開腹され Gross 6 型の胆道閉鎖
と診断された。この時の生検標本には14コのグ鞘中 $7 \beth$ に胆管がみられたが種々の程度の胆管上皮の変性像が見 られた．剖検で肝管の約 $180 \mu$ の内腔を有し存在してい た．肝実質には胆管は完全欠損をしていた，肝硬変はな く胆管增生も見られなかった. 肝外胆道閉鎖症との組織 像の違い，生検標本の胆管上皮障害像等から肝内胆管が primary に障害を受けたものと考えた。

座長まとめ $(20 ２ 6 ）$

東京大学小児科

白木 和夫

第20席に対し志方（日大）らはその一部症例が Wilson 病である可能性を指摘した，小児期の急性および慢 性肝障害の診断に 当っては常に 先天代謝異常, とくK Wilson 病の鑑別が重要であり, ceruloplasmin のみなら ず尿中銅定量などが必須である. 第21席に対し志方 (日 大), 大林 (都立駒込) から生後の 水平感染の可能性が 質問されたが，演者はその可能性が少ないことを述ぺ た. 第24席に対し座長から小児期の肝硬変としてはHBs 抗原陽性例が多い点が指摘され，家族集積性について訊 ねたが，その傾向は無かったという．第26席に対して福 田（順天大病理）から肝門部閉塞の有無，肝内胆管消失 がそれによる二次的なものではないか，胆管が少ない、割 に胆汁らっ滞が軽いとの意見が出されたが，演者は組織 像が肝外胆道閉鎖と異なる点から一次性と考えると主張 した，座長から Alagille 症候群の可能性について質問 したが，末梢性肺動脈狭窄などは無かったとのことであ った.

\section{7. 肝不全とその対策}

聖マリアンナ医科大学第 2 内科

志沢 喜久，河野 誠

岩㹸 省吾, 岡部 和彦

主として実験的急性肝不全に於けるフミノ酸代謝動態 之特殊組成了ミノ酸輸夜製剂（以下 GO-80）の治療効 果を検討した，方法は Guinea pig を用い，Keppler の 变法にて D-Galactosamine を腹华内投与し，26時間後 よりGO-80+Glucose, Glucose 単独の 2 群炕分け点滴 した．非点滴群では血浆アミノグラムはヒト尉症肝炎の それと汪添類似して括り，GO-80+Glucose 投与群では 血踉及び脳アミノグラム異常が是正され，一方 Glucose 単独投与群でもフミノグラム異常はかなり是正された。 しかし両群ともComa の改善は明らかではなかった。肝 
㙨能障害は非点滴群に比して点滴群では軽度であった。 さらに実験開始24時間後より低血桾の出現が目立った が, Fastingのみでは認められず，肝不全に起因した糖 代謝異常と考光られた。

\section{8. 劇症肝炎患者血清中 の 肝再生阻害物質 の} 吸着剤による除去

東京大学第 1 内科

\begin{tabular}{|c|c|c|c|}
\hline 林 & 茂樹, 藤原 & 研司, 三代 & 俊治 \\
\hline 尾形 & 逸郎, 山崎 & 誠行, 金 & 乙祥 \\
\hline 鳥居 & 正男, 太田 & 裕彦, 高築 & 勝義 \\
\hline 田 & 吉博, 堺 & 隆弘, 岡 & \\
\hline
\end{tabular}

肝疾患患者血清のシロネズミ培着肝細胞の DNA 合成 に与える影響からとト血清には肝再生促進物質 (S) と その阻害物質 (I) が存在することを報告した。疾患の 経過でこの 2つの物質の動きをみると，重症急性肝炎で は極期には S,I ともに低く，回復期に至るに従って両 者上昇し，IKついては再び低下がみられた。劇症肝炎 死亡例では, 病初期 $\mathrm{S}, \mathrm{I}$ ともに高いものが経過ととも に減少するのみであったＩ と吸着剤との関係をみる と, その種類（活性炭，アンバーライト XAD-2）によ り，吸着後の DNA 合成に与える影響が異なりまた DNA 合成とタンパク合成とを比へて吸着剤の効果が異 なっていた. 訮不全対策としての吸着剤応用にあたって は，これらの点を十分考虑する必要がある.

\section{9. 血䍝遊離 アミノ酸レベルからみた 劇症肝 炎の予後とその対策 \\ 岩手医科大学第 1 内科

田中盛太郎, 海藤 夏, 佐藤 俊一
千葉 勤, 中沢 一臣, 遊佐不三雄
鉿木 一幸, 鳥谷 宗正, 阿部 裕行
加藤 章信

昏睡時に血浆遊離フミノ酸（PFAA）を湘定しえた劇 症肝炎14例について, 総了ミノ酸量 (TFAA), Phe+Tyr (AAA), val+Leu+Ile (BCAA), Met などの PFAA レ ペルから劇症肝炎の予後との関連について検討した. ま た Charcoal hemoperfusion (CH) を施行した 4 例につい て PFAA の変動からその効果を検討した，劇症肝炎14 例中急性型 6 例, 亚急性型 8 例であり, 生存は亜急性型 の1例であった. TFAA 及び Phe+Tyr は昏睡発現ま
での期間の短い急性型汪ど高く，重症度を反映すると思 われた。 BCAA/AAA 比は急性型と亜急性型で差はない が, 生存例の比は高い. CH 施行例では生存期間の延長 がみられ，意識改善例では TFAA，Phe+Tyr, Met の減 少がみられた.

30. アミノ酸（MO-80）療法における glucose 併用の意義一生化学的レベルからの検討 岩手医科大学第 1 内科
鈴木 一幸, 海藤
勇, 佐藤 俊一
石井 隆, 遊佐不三雄, 小岡 文志
鳥谷 宗正, 田中盛太郎

我々は肝性昏睡に MO-80療法を行ない，その効果が 極めて優れていることを報告してきた，今回，本療法に おける glucose 併用の意義を実験的・臨床的に検討し た. 動物実験では Eck 瘦犬にMO-80単独および glucose 併用投与を行ない，さらに Insulin, Glucagon の血将遊 離アミ，酸に及ばす影響について検討した. 臨床的には 肝性昏睡18例 (劇症肝炎 4 例, 肝硬変14例亏ち肝癌合併 4 例) について有効例 (12例) 不変例 (6 例) でその差 をみた. Eck 瘦犬では glucose 併用群で Phe, Tyr の有 意の減少を認め, 臨床例でる有効例で Phe, Tyr の減 少がみられた. glucose 併用では IRI の高反応および IRI/IRG モル比の上昇がみられ，これが本療法の効果 に有効性に働くことが示唆された.

\section{1. 特殊粉乳 LP-14 による肝性昏睡の治療 三井記念病院消化器センター内科 沢田 準, 小篮原 憲, 鵧沼 直雄}

肝性昏睡における血将了ミノ酸アンバランスの改善を 目的としたアミノ酸療法は従来主として経静脈的に行な われて来たが,演者らは特殊組成アミ，酸含有粉乳LP-14 （雪印乳業）を経口的に投与し，肝性岳睡に効果を認め たので報告する．LP-14はフェニルケトン疗症の治療の ために使用される特殊粉乳であり，フェニールアラニ ソ，チロジン含有量は 0 となっている，症例 $1 ， 64$ 歳, 男. 肝硬変. 肝性昏睡 3 度に対しラクッロース無効で, 4 度に進行したため LP-14を投与し，意識は完全に清 明となった. 症例 $2 ， 50$ 歳，女. 肝硬変. LP-14のみの 投与で 昏睡 2 度から 意識清明へと改善し，BCAA/AAA 比も，1.02から1.64に上昇した。症例 3,48 歳, 男. 肝硬 変. 皆睡 3 度から 1 度に改善した。 


\section{2. 急性肝不全における合併症の検討} 横須賀共済病院内科

金山 正明, 小泉 精策

坂本 龍, 東海林隆男

劇症肝炎自験例21例について肝不全経過中の合併症を 臨床面と剖検所見から検討した. 対象症例はウイルス性 肝炎 (HBs 抗原陽性 5 例) 20例，薬物性肝障害 1 例で救 命例は 2 例のみであった. 主要合併症としては出血76.2 $\%$ ，とくに消化管出血 $61.9 \%$ ，急性腎不全 $72.2 \%$ ，腹水 眝溜 $47.6 \%$ ，肺炎 $28.5 \%$ ，その他の感染 $19.0 \%$ ，急性脺 壊死 $14.3 \%$ どが高頻度にみられた. 消化管出血は急性 肝不全の各時期にみられ，剖検所見から消化管粘膜のび らんや粘膜出血によるむのが大部分を占め, 凝血因子八 ラメーターの程度とは直接の関連はみられなかった。 急 性㛑不全は全例が 非乏尿性で血清クレアチニン値は 2.0 $\mathrm{mg} / \mathrm{d} l$ が $57.2 \mathrm{mg} / \mathrm{d} l$ で組織所見でも尿細管上皮の変性壊 死を示すものは少く機能性腎不全が主体と考えられた。

\section{3. 肝疾患における $\beta$-thromboglobulin の} 検討

\section{岩手医科大学第 1 内科}

吉田 俊巳，海藤 勇，佐藤 俊一 遊佐不三雄, 鈴木 一幸, 柏原 紀文 村上晶彦

肝疾患に郝ける血小板機能，主に血小板固有蛋白であ $\eta ，$ 血小板から放出される $\beta$-thromboglobulin（以下 $\beta$ TG) を中心に検討した. 血小板数は慢性肝疾患になる に従い減少し，血小板粘着能は急性肝炎で高い傾向を示 した，血小板数と血小板粘着能では有意に正の相関を示 した. $\beta$-TG は健常者 $27.9 \pm 10.0 \mathrm{ng} / \mathrm{m} l$ に対し, $\mathrm{DIC}$ 例 で著明な高值を示し，全例 $100 \mathrm{ng} / \mathrm{m} l$ 以上であり，FDP も $40 \mu \mathrm{g} / \mathrm{m} l$ 以上であった. また肝疾患別では特に差はな いが，急性肝炎，肝癌で $100 \mathrm{ng} / \mathrm{m} l$ 以下の中等度の值を 示す症例がみられ，これらの疾患に血栓形成傾向のある ことが示唆された。 また FDP 患でもしばしば上昇するが， $\beta$-TG は DIC に特異的之 考えられ，DIC の診断にはFDPよりる有用と思われ た.

\section{座長まとめ（27～33）}

岩手医科大学第 1 内科佐藤 俊一

$27,29 ， 30 ， 31$ 席は肝不全のアミ，酸代謝異常と特 殊組成了ミノ酸療法の効果に関するもので，27，30席で はアミノ酸の輸液，31席は経口投与による治療であっ た. 輸液では MO-80又は GO-80と glucose の併用が 論ぜられ, 併用 glucose 量はどの程度のカロリーが必要 かか問題では Fischer らと同様に実施しているのが現 状で，今後の検討が必要である. また glucose 単独で す血浆遊離アミノ酸の改善をみることが注目された。経 口投与ではアミノ酸の吸収の問題があるが, 輸液と同様 の治療効果を得た成績で祭った，28席は肝再生阻害物 質，肝再生促進物質火関するるので，それら物質の本 態，正常にも存在するかとの問題が論峙られ，今後検討 すべき重要な課題である．32席は合併症として消化管出 血，腎不全などが重視されたが，消化管出血と endotoxin との関連も今後の問題と考えられた。.33席は $\beta$-TG は DIC の診断に FDP より有用との報告で今後の検討が 望まれる.

\section{4. 赤血球増多症を 伴った 原発性肝癌 の二症} 例

北海道大学第 2 内科

渡適 正夫, 鎌田 吉和, 山口 彰 筥崎堅次郎, 牧野 勲, 中川 昌一

原発性肝癌に腫瘍随伴症候として赤血球増多症を伴ら ことは比較的まれであるが，最近，二症例を経験した。症 例 $1 ： 47$ 歳男性. 諸検查により肝両葉に及ぶ原発性肝癌 の病巣を認め, AFP は異常高值 $(348,722 \mathrm{ng} / \mathrm{ml})$ を呈し た. 血液学的検查は RBC $693 \times 10^{4}, \mathrm{Ht} 58.3 \%$, erythropoietin は血中 $56 \mathrm{~m} . \mathrm{i} . u . / \mathrm{m} l$, 尿中 $150 \mathrm{~m} . \mathrm{i} . u . / \mathrm{m} l$ であった. 症例 $2: 66$ 歳男性, 諸検查により肝右葉飞原発性肝癌 の病巣を認め, AFP は異常高值 $(99,026 \mathrm{ng} / \mathrm{ml})$ を呈 した. 血液学的検查は RBC $682 \times 10^{4}, \mathrm{Ht} 57.7 \%$, red blood cell volume $80 \mathrm{ml} / \mathrm{kg}$ と堌加，骨髄所見で有核細 胞数 $13.5 \times 10^{4}$, NAP (rate 96. score 264) と正常範囲 であったが, erythropoietin は血中 $100 \mathrm{~m} . \mathrm{i} . u . / \mathrm{ml}$ ，尿中 150m.i.u./ml の高值であった. 以上の所見から，い寸゙れ の症例も, 揰瘍からの erythropoietin 麾生に起因する赤 血球增多症と推定された。 
35. HBs 抗原陽性肝線維症に発生し特異な組 織像を呈した原発性肝癌の一例

東京女子医大消化器病センター 本池 洋二, 奥田 博明, 武藤 晴臣 高崎 健, 久満 董樹, 林直諒 小林誠一郎, 小幡裕

都立豊島病院内科藤原 純江 症例 36 歳男性. 昭和51年 7 月健診時肝機能正常, HBs 抗原陽性, 11月 AFP 2,100ng/m $l$. 精查の 結果肝線維症に 発生した肝癌と診断，52年 3 月肝右葉切除術施行， 2 年 8 ケ月後の現在再発一, 尰瘍は肉眼的に小塊状型, 灰白 色硬性で分葉状増殖する尰瘤の集合より成る光影的に腫 惶細胞が主に索状配列し小型で細胞質乏しく間質が毛細 血管より成る部(1)，間質に細線維を有しロゼット様配列 を示す部(2)，線維性結合織の間質を有し管腔形成を示す 部(3がありその間の混在，移行す見る. 電顕的に(1)の部 は細胞小器官が発達し円形核を有す細胞が敷石状配列し 毛細胆管様楧造も見られ肝細胞癌様で，(3)の部は長方形 細胞より成り腔側表面に䄉毛，細胞間面に指状陥入を認 め基底膜すあり胆管細胞癌様である。

36. carbazilquinone (CQ) 間歇動注療法が 著効を奏した原発性肝癌の一例 東海大学第 3 内科

$$
\begin{aligned}
& \text { 松崎 松平, 板倉 勝, 上野 文昭 } \\
& \text { 杉本 栄一, 稲葉 允, 岩村健一郎 }
\end{aligned}
$$

症例 : 49歳男, 主訴; 心窩部痛, 体重減少, 昭53年 8 月より主訴出現，同 9 月 22 日当内科入院，クモ状血管 腫, 手掌紅斑 (H), 肝 $10 \mathrm{~cm}$ 触知, 硬, transaminase, AP, LDH, $\gamma \mathrm{GTP}, \gamma$-globulin 上昇, AFP $62 \times 10^{4} \mathrm{ng} / \mathrm{m} l$, 肝ンンチグラム, 腹腔動脈造影より, 肝硬変合併肝細胞 癌と診断. CQ $8 \mathrm{mg}$ one shot 動注を $2 \sim 4$ 週毎に6回反 復施行. 第 2 回目より肝腫は消失, AFP は半減期 7 日 の速度で $3,000 \mathrm{ng} / \mathrm{ml}$ 迄低下，以後著增妇みられず，肝 機能も改善し，発症後14ケ月元気に生存したが，昭54年 10月急性胃潰瘍出血のため死亡. 剖検により肝兩莱上部 被膜下と右葉外側に指頭大の限局 した肝癌の残存が確認 された (Edmondson II 型). CQ の賦活には肝小胞体に 於いて NADH を介した系の作用も考光られ，肝癌治療 に有效な薬刜の一種と考える.
37. CT スキャンにより診断され切除しえた細 小肝癌の一例 養育院付属病院消化器科 竹越 国夫, 深沢 俊男, 斉藤 恵実 五島 亨, 紀 健二 同放射線科山田 英夫 同病理嶋田裕之 国立ガンセンター外科

長谷川 博, 山崎 晋

近年, 肝癌の早期診断法のうち, 肝 CT スキャンの 役割が注目されている. 我々は， $\alpha$-Fetoprotein (AFP) の軽度増加, 及び訮 CT スキャンにより診断され, 肝 部分切除を受けた細小肝癌例を経験したので報告する.

54歳，男，肝炎既往のある大酒家. 昭和52年 3 月，鼻 出血を主訴として来院し，慢性活動性肝炎と診断され た. 昭和53年 6 月, AFP $169 \mathrm{ng} / \mathrm{ml}$ より $320 \mathrm{ng} / \mathrm{m} l$ K増 量し, 肝 CT スキャンで, 直径約 $2 \mathrm{~cm}$ 大の低X線吸収 性円形病巣を認め, 肝癌を推定した。肝血管造影による 病巣確認後, 昭和53年 9 月, 肝右葉前区域切除術方施行 した. 大豆大までの娘結節 $3 \sim 4$ 個を有する $2.5 \times 2.4 \mathrm{~cm}$ 大の肝細胞癌 (Edmondson's grade II 〜II) であり, 、非 癌部は乙型肝硬变であった.

\section{8. 多彩な組織像を示した細小肝癌の 1 例}

$\begin{array}{cr}\text { 北里大学病理，佐々木憲一，中 英男 } \\ \text { 北爪 伸二, 奥平 雅彦 } \\ \text { 同外科 } & \text { 三重野寛喜 } \\ \text { 同内科 } & \text { 柴田 久雄 }\end{array}$

症例 55歳 男. 昭和 49 年秋痔核 - 出血に気付くも放 直. 翌50年10月タール便・吐血があって来院. 検査の結 果肝硬変及び食道静脈瘤と診断され，51年 2 月食道離断 術を施行したが, 術後 7 カ月で腹水再貯留・感染合併し て術後 7 カ月で死の転帰をとった. 尚 HB Ag 陽性, AFP $36 \mathrm{~m} \mu \mathrm{g} / \mathrm{ml}$ であった.

剖検するに，肝は $850 \mathrm{~g}$ と著しく萎縮, 複小葉性薄間 質性肝硬変 (乙) であった. 肝右葉觉隆部に径 $1.2 \mathrm{~cm}$ 大 の灰白色尰瘍があり，肉眼的に数個の分葉をみとめた. 組織学的には多彩で, 通常の薄索状分化型肝細胞癌の 部, 蜂巣状配例の部, 密な間質を伴兄る部分, 腺管状配 列を示す部分があって，これらがモザイク状に混在し， 全体として結節状病変を形成するものであった。 
39. 2 年以上経過をみた細小肝癌の 2 例 札幌厚生病院消化器内科

塚越 洋元，近間 敏治，石 昌事

堀田 彰一，八百坂 透，須賀 俊博

三和 公明，村島 義男

同 外科長谷川紀光, 前田 暨 北海道大学第 1 外科

症例 1 は 51 歳男.HBs-Ag 陽性乙型肝硬変で AFP が 850 と湩增し肝シンチで SOL を認め超音波，CT，血管

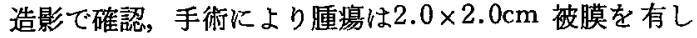
内部は necrose で肝細胞癌は管状あるいは索状に配列し ていた。症例 2 は65歳男.HBs-Ag 陰性の慢性肝炎で AFP が 100 前後と微量陽性化, 肝シンチで SOL を認 め，CT，超音波，血管造影て陽性所見を得，超音波映 像下吸引細胞診にて確認を得, 手術で右葉外側に $3.9 \times$ $4.0 \mathrm{~cm}$ の被膜を有する分化型の肝細胞癌を認めた.

\section{座長まとめ（34～39）}

東海大学内科松崎 松平

34席では，赤血球增多を伴亏肝癌 2 例に括いて，血 中，尿中 erythropoiethin の上昇が示された．現在その 上昇機序に関して，論議は分れているが，肝癌組織中の 活性測定の結果に 興咮がもたれる．35，38席では，い すれれむ限局した小肝癌中に多彩な組織像の混在した稀 な症例が提示された．36席では．肝癌比対し， carbazilquinone 間歇動往の有效例がみられることを述べた，CQ はその賦活系路が他剤之やや異り，その特徵を生かした 今後の研究に興味がもたれる。 37席では CT scan の撮 影条件の改善に上り，肝癌の早期診断と手術治療が可能 であった症例が示され，39席に批いても，CT と超音波 法下の穿刺吸引生検の組合せにより，手術可能な細小旰 癌の 2 例の診断が可能であったことが報告された，北里 大外科上り，肝動脈アンギオと CT 同時施行により， 肝癌 CT 像がより明確になる場合のあることが追加さ れた．肝癌早期診断への進歩がうかがわれる報告であっ た.

\section{4 年10ケ月の 経過をとった 原発性肝癌 の} 一剖検例

北里大学消化器内科

北井 則夫, 中沢 秀昭, 福井光次郎

山田 伸夫，真玉寿美生，石井 公道

柴田 久雄, 岡部 治弥

同病理早坂徹

症例52藏男，14年前より糖尿病に霍患，昭和49年 8 月 旰障害精查のため入院. 肝 Scan にて左葉の cold area $(+)$ ，血管造影飞て caver nous hemangioma 样陰影を認 めた。 その後， 4 ケ月後と 1 年 9 ケ月後の血管造影の度 飞腫痛陰影は膨脹性腫大を示し，さら飞 4 年 5 ケ月後の 血管造影で，肝全体に腫瘍が広がり，癌の浸潤性発有が 認められた。昭和54年 5 月，肝不全のため 死亡。AFP の経過中陰性で男ったが死亡直前 $906 \mathrm{ng} / \mathrm{m} l$ 飞增加し た. 剖検では，肝は $2,700 \mathrm{~g}$, 両葉に被膜を有する手拳大 の肝癌があり一部浸潤性に肝内転移を抗こし組織学的飞 は Edomondson II 型であった，本例は，血管造影に て，肝癌の膨脹性発育から浸潤性発育への移行を 4 年 10 ケ月にわたり観察しえた slow growing hepatoma の症 例であった。

\section{1. 黄疸を主症状とした原発性肝癌の 2 例 北里大学外科 \\ 筫浦 宏彦，鎗水 民生，佐藤 光史 大宮 東生，阿兽 弘一}

我々は，黄痹で発症した原発性肝癌の 2 例を経験した ので 報告する. 症例 1 は59歳 男性. 著明な 黄疸にて来 院. 胆囊腫大を認めたため胆㖶外瘦を扎いたが効果なく 7 日目に死亡した. 剖娭では肝門部に $3.5 \times 2.5 \times 2.5 \mathrm{~cm}$ 大の肝癌があり，胆管内に腫瘍塞栓を認めた．症例 2 は 50歳男. 黄疸と発熱にて来院. 緊急で血管造影を行な い，著明な AP シャントを認め䀒癌と診断した．持続 抗癌剤動注を行ったが効なく死亡した. 剖検では, 肝門 部に徍 $2 \mathrm{~cm}$ の肝癌があり，門脈及び胆管に浸潤を認め た.

原発性肝癌で，閉塞性黄瘟を来するのは稀であるが， 肝門部に存在するものでは，比較的小さくても黄庭を来 すことがあるので注意を要する，黄疸の診断には PTC が有効であるが血管造影で AP シャントを見つけるこ とは訮癌を診断する上に有効と思われる。 
42. アトリアシン投与中血中 HBs 抗原陽性と なったへパトーマの 1 例

県立岐阜病院内科 福田 信臣, 小島 峑雄, 広瀬 洋 青山 政史, 小林 成禎, 大島健次郎 養老中央病院内科宇土一道

症例，50歳男子，主訴，全身僚意感と右季肋部痛，既 往㭱，昭和43年慢性肝㷋，現病歷，53年 4 月初旬より症 状出現. 5 月 1 日入院, 肝右乳線_上 4 横指触知, 腹水な ᄂ. 検査所見，黄疸指数 $16 ，$ GOT 270, GPT $30, \mathrm{LDH}$ 1,045, $\gamma$ mGT 257, TChol406mg/dl, ChE 0.27, AFP $20 \mathrm{ng} / \mathrm{m} l$ 以上，胸部レントゲン上肺転移䉓あり，肝ンン 千で右葉次損像. HBsAg, anti-HBs 共浍性 (RIA), anti-HBC $2^{12}$.アドリアシン10ng/日 6 日通続投与，10日 間休薬法により肝欠損像, 肺転移巣縮少，8月13日クー 儿後 HBsAg $2^{3}$ (R-PHA), HBeAg, DNA Polymerase む出現. anti-HBc $2^{12}$ と不変. しだい代黄㾝強く, 意識 障害をきたし，54年 2 月 4 日死亡. アドリアンンによ り，HB ウイルスが活性化された症例と考党た。

\section{3. 特異な経過をとった肝細胞癌の一例} 虎の門病院消化器科

小宅 映士, 煎田 博光, 竹内 和男 中島 正男, 吉場 朗

同 病理学科遠藤 雄三

症例は33歳男性, HBsAg 陽性. 母親が朋硬変で死亡. 昭和52年11月頃上り左前胸部痛. 同53年 1 月には，左腰 痛之 $38.5^{\circ} \mathrm{C}$ 発熱炕気付き， 3 月 3 日入院. 入院後，腹 胫鏡にて左葉に手拳大の盰外性発育をした Hepatom を 発見した為，5月12日左葉切除術施行． 7 月 3 日には扁 桃飞 Polyp 様の転移を発見. 8 月 2 日，扁桃摘出術施 行. 同12日ジャクンン型てんかんが起こり，10月22日， 全身衰弱の為, 死亡. 剖検では胃体上部粘膜より Polyp 状に発育した転移を始め，副腎，上咽頭，頝部，大脑両 半球に多数転移を認めた。 以上，原発巣及び転移巣での 発育が Polyp 状を呈し，扁桃転移をきたなど，特異 な臨床経過をたどった肝細胞癌の一例を経験したので報 告する。

\section{Subtype の異なる 2 種類の $\mathrm{HBV}$ 感染を みた $\mathbf{H B V} \cdot$ 肝癌集積家系の 1 例}

三井記念病院消化器センター内科 増田真一郎，鵜沼 直雄

症例は44歳，女. 昭和38年の帝王切開の際，翰血受 け黄㾝の出現をみている. 昭和52年 I 月, 当科を受診 し, 肝硬変々䛦断されたが，HBs 抗原 $2^{9}, \mathrm{HBs}$ 抗体 $2^{4}, \mathrm{HBc}$ 抗体 $2 \geqq^{15}$ であり，HBe 抗原・抗体は一であ った. HBs 抗原の subtype は adw，HBs 抗体には antir が証明された，尚，同胞 5 人は全員 HBs 抗原十であ り，ちち，弟と妹を含め 3 人は同し adw であった. 同 胞のキァリアーを成立させた HBV は adwであり,

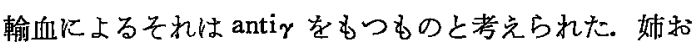
よび目は肝癌で死亡していた，症例の娘 2 人，19歳と16 歳は HBV キァリアーであるが，すでに HBe 抗体が 出現して特り，次の世代には感染しないであるうことが 予想された.

\section{Cholangiocarcinoma $の 一$ 剖検例}

埼玉医科大学第 3 内科

$\begin{array}{ll}\text { 玀 } & \text { 添財, 今井 史彦 } \\ \text { 矢部 諭, 伊藤 進 }\end{array}$

症例は68歳の女性，昭和53年 8 月頃から心窩部の圧迫 感が西り11月には全身僚意感も出現，昭和54年 2 月近医 以て肝腫大を指摘され 4 月当科外来受診後入院. 肝は著 明汇腫大し GOT $179 \mathrm{mu} / \mathrm{m} l \mathrm{GPT} 35 \mathrm{mu} / \mathrm{m} l \mathrm{LDH} 600 \mathrm{mu} /$ $\mathrm{m} l$ Alp $160 \mathrm{mu} / \mathrm{m} l$ T. Bil $0.8 \mathrm{mg} / \mathrm{m} l$ AFP $7 \mathrm{ng} / \mathrm{m} l$ CEA $3.2 \mathrm{ng} / \mathrm{m} l$ 肝ンンチで肝全体に大きな SoL がみられた. 生検により Cholangiocarcinoma を疑った. 剖検時, 肝 は500g で腫㰾部分が全体の $90 \%$ 以上占めていた，副腎 に血行性転移とみられる病巣を認めたが他臟器には腫瑝 部分はみられず，組織学的に胆管系細胞由来の peripheral から発生したと考えられる cholangiocarcinoma と 診断された.これは Alpert 等の分類によると Ductal type に相当するものと考光られます，肝腫浧が巨大で あるにもかかからず経過中，黄疸がみられず診断的に興 味㐬る症例と思われ，ここに報告しました。

座長まとめ（40～45)

三井記念病院消化器センター内科

鵜沼 直雄

40は経過の長い encapsulated の肝癌の報告であっだ 
$134: 932$

肝

茷

41は肝癌の臨床型の中では最る頻度の少い cholestatic type であり，頻度は Okuda, Peters によれば0.7\%にす ぎない，42の，以前から HBc 抗体が高抗体価を示して いた肝癌患者にアドリアンンを投与したところ HBs 抗 原が出現， HBe 抗原も陽性となった例は，ウイルス活 性化因子に対し示唆を与えるるのであった. 43はポリー プ状で扁桃にまで転移をみた特異な旰癌であった４44は 悲惨な HBV 集積家系の報告であったが，唯一の救 いは最む若い世代の19歳と16歳の娘がすでに HBe 抗原 から HBe 抗体へと seroconversionを起していることで あった.この傾向は最近指摘されて扣り，母子感染の将 来に明るい話題を与えるすのであった４54肝のほぼ全 体を占める腫瘍にもかかからず最後まで黄疸のみられな かった特異な症例であった。

\section{6. 右葉切除後 5 年経過 した肝癌の 1 例} 浜松医療センター外科消化器科

内村 正幸, 武藤 良弘, 脇 慎治 林輝義, 䚗島 恭彦, 瀬川 徹 小原 則博, 室久敏三郎, 山田 秀雄

過去 7 年間に原発性肝癌 6 例, 転移性肝癌 11 例の計 17 例に肝切除を施行した．右葉切除 5 例，左葉切除 1 例， 左葉外側区域切除 6 例, 中葉部分切除 4 例, 及び左右部分 切除 1 例である，手術死亡はない，原発性肝癌 6 例では 1 例が，1年 6 ケ月で死亡したが，他の 5 例は生存中 で， 2 例に， 4 年11ケ月， 5 年 4 ケ月の長期生存例があ る.

症例. 56 藏男. 昭和 49 年 5 月右季肋部腫瘤 で入院し た. 肝譏能は正常範囲で，血管造影肝シンチで肝癌と診 断した. $\alpha-\mathrm{F}$ は2,020ng/ml の高值で肝右葉切除 $(15 \times 12$ $\times 12 \mathrm{~cm} 730 \mathrm{~g}$ ) 後 $9.22 \mathrm{ng} / \mathrm{ml}$ と下降した. 組織学的に肝 細胞癌であった。昭和53年10月 $\alpha-F$ の上昇で肝左葉転 移を発見し，54年 2 月 $\alpha-\mathrm{F} 24,800 \mathrm{ng} / \mathrm{ml}$ と上䒜した。 現在外来で FT207服用 L就労中である.

\section{7. 肝癌切除後 の 長期生存例一肝癌切除後} 累積生存率と 5 年以上生存例の検討 東京大学第 1 外科

$\begin{array}{lrr}\text { 水田 } & \text { 哲明, 菅原 克彦, 河野 } & \text { 信博 } \\ \text { 三谷 進, 大多和俊行, 長尾 桓 } \\ \text { 金高 伸也, 草間 悟 }\end{array}$

原発性肝癌は進行癌で診断されることが多く，かつ肝 硬変が高頻度に併存するために，切除療法の適応が限ら
れ，また切除療法の遠隔成績も不良である.今回われわ れは過去16年間に経験した原発性肝癌切除例52例につい て累積生存率を求め, その要因について検討を行った。 5 年累積生存率は硬変併存群で $4 \%$, 硬変非併存群で17 \%で，60日以内に死亡したものを手術死として除外する と，前者が $4.9 \%$, 後者が30\%で明らかに後者が良好な結 果を示していた.この52例中 5 年以上生存例は 4 例で， 硬变併存例 1 例, 非併存例 3 例で 4 例とも左葉切除例で コランジオーム例には切除後長期生存例はなかった.こ の4 例について詳細に検討した結果を述べた。

\section{8. 肝癌切除後の 長期生存例一その 臨床病理 学的検討

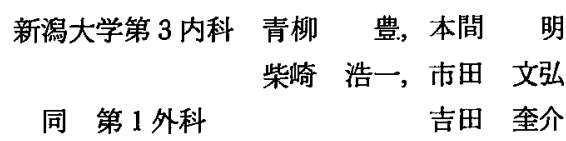 \\ 国立ガンセンター外科}

長谷川 博, 山崎 晋

我々が過去10年間に経験した原発性肝癌は, 104例 （細小肝癌 6 例を含む）でそのらち切除を行ない得たも のは6例 $(5.8 \%)$ であった.これらの症例のらち年余 にわたる長期生存例は 3 例で，最長は 5 年14日である. 長期生存例の肝硬変合併は 3 例中 1 例でこの例も乙型の 軽度のものであった．特に65歳の高齢者でも非合併例で は拡大右葉切除 $(1,810 \mathrm{~g})$ といら広範な手術侵襲にもた えられた。一方手術施行例では, 血清 AFP 值は全例陽 性であり，0.4 $93 \mu \mathrm{g} / \mathrm{m} l$ の值を示したが，長期生存と の関連は認められなかった. 又最長生存例は細小肝癌の 範俦に入るるの $(3 \times 3 \mathrm{~cm})$ で，43歳と比較的若い症例 であった. 以上より長期生存の条件として, 肝硬変合併 の有無, 残存肝機能の程度, 腫瘍の大きさおよび占拠部 位，年齡などがあげられる。

座長まとめ $(46 \sim 48)$

東京大学第 1 外科

菅原 克彦

原発性肝癌に対する治療は切除療法が最すすぐれてお り，本庄一夫学長により肝硬変併存肝癌切除17年後に交 通事故死したが癌は存在しなかった報告がみられる。最 近血清指標や画像診断によって細小肝癌の報告がみられ るが 3 年毎に行われる日本肝癌研究会の集計にはあらわ れていない。原発性肝癌切除の適応は厳格にしても直接 死や再発死が多く第 4 回日本肝癌研究会の報告では 5 年 以上生存は 6 例にすぎない現状である.内科側で 5 年以 
上の生存を期待する切除適応条件には訮硬変が併存しな い，睡瘍の大きさは関係ないが非癌部で切除し得ること などがあげられたが，これらが満されてる癌の組織型や 異形度のほか臨床的な発育史が関係するので症例をつみ 重ねた検討が必要である. 水田によると切除した52例の 累積 5 年生存率は23\%であるが，肝硬変や癌の病期を勘 案したさらに精細な臨床的観察が他施設の報告とあいま って切除適応の指針となり得るるのと期待された。

\section{9. 肝胆道疾患と血清胆汁酸}

聖マリアンナ医科大学第 2 内科

$\begin{array}{llll}\text { 中込 } & \text { 健郎, 藤井 守, 水口 } \text { 明洋 } \\ \text { 前山 } & \text { 史朗, 鈴木 } \text { 博, 岡部 和彦 }\end{array}$

肝䏣道疾患患者の空腹時血清胆汁酸を 254 検体 測定 し，肝機能検查および病態との関連を検討した，I）胆 汁酸は肝機能検查の らら GPT $(r=0.458)$, 総ビ $(r=$ 0.402) 以下 GOT, GPDA , LAP, $\gamma$ GTP, Al-p の順で 相関した. II ) a : 疾患別では劇症肝炎 (240.2土119.7 $\mu \mathrm{M})$, 胆汁万っ滞性急性肝资 (219.8土140.0) 同薬剂性

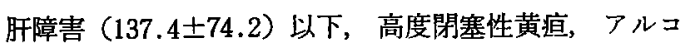
ール性肝炎, 非胆汁与っ滞性急性肝炎, へパトーマ, 慢 珄肝内胆汁うっ滞, 非代償性肝硬変の順で各々高值を示 した. b : $200 \mu \mathrm{M}$ 以上の高值例は14例 (5.5\%) で重症 ないし 難治性であり，大多数例は $200 \mu \mathrm{M}$ 未満であっ た. III）䏣汁酸の上昇機序には肝実質障害，胆汁 5っ滞 牤よび短絡形成の関与が考えられるが他の肝機能検査と の関連から前 2 者が同程度に強く, 次いで短絡形成が関 与する事が示唆された。

50. 胆汁酸負荷試験 の基礎的検討一同一人に おける軽食, 卵黄, ウルソデオキシコール酸 (UDCA)，コール酸 (CA) 負荷の比較検討 帝京大学第 1 内科

佐野 直代, 佐藤罍美子, 山中 正己 木下 忠俊, 中村 孝司

健康人19例, CIH 14例, CAH 8例, LC 8 例, その 他肝疾患 5 例, 胆石 21 例飞ついて UDCA $500 \mathrm{mg}$, 卵黄 による試験を反復し，また，健康人のうち10例に対して は更にコール酸 $500 \mathrm{mg}$ ，軽食による負荷を加えた。胆汁 酸濃度は醭素法により総胆汁酸，一次胆汁酸の測定を行 った. 各負荷法の中では血清総胆汁酸濃度上昇の程度は UDCA が最高であった. 症例の一部では UDCA 負荷
後一次胆汁酸の増加を見る場合があり内因性胆汁酸の負 荷が加わる事が示唆された. CAH，LCでは空腹時およ び peak の異常を示す者が多く，CIH では卵黄に比し UDCA $500 \mathrm{mg}$ の方が有意に異常率が高く肝疾患の検出 感度が優れる成績を得た。

\section{1. 体質性黄瘨におけるウルソデオキシコー ル酸（UDCA）経口負荷試験 中央鉄道病院消化器内科 順天堂大学消化器内科 南部 勝司, 上田 英雄 山城 雄二, 浪久 利彦} Gilbert 症候群（GS） 2 例, Crigler-Najjar 症候群 II 型 (CNS II) 1 例, Dubin-Johnson 应候群 (DJS) 3 例, Rotor 症候群 (RS) 15例，体質性 ICG 排泄異常症 2 例 の空腹時血清胆汁酸を GLC で測定し，さらに，DJS と RS の各 1 例で, UDCA $300 \mathrm{mg}$ 経口負荷後の, 血清胆 汁酸の経時的変化を観察した。

結果；1）体質性黄疸の血清総胆汁酸值は必ずし子正 常ではなかった．2）血清総胆汁酸が高値を示した症例 の胆汁酸組成比は病態によって差がみられ，CNS II と RS では CDCA が，DJS では CA が増加していた. 3） UDCA 血中消失曲線は DJS と RSで異なったパタ ーンを示し，また UDCA の血中消失に伴ってみられた 内因性胆汁酸の変動わ, DJS と RS で差がみられた。

\section{2. 肝機能検查としての胆汁酸測定} 東京大学第 1 内科 田中 直見，鳥居 正男，織田 敏次 筑波大学臨床医学系内科大菅 俊明

目的：顕性黄疸がなく（総ビリルビン $2.5 \mathrm{mg} / \mathrm{d} l$ 以 下)，トランスアミナーゼ150以下の慢性肝疾患に拈ける UDCA 負荷試験の臨床的意義, 血清総胆汁酸と常用肝 機能検査との相関及び各肝機能検査の鋭敏さにつき検討 した. 万法 : 組織学的確診のついた慢性肝资非活動型 10例, 活動型24例, 脂肪肝 6 例, 食道静脈瘤を伴なわな 、肝硬変19例, 食道静脈瘤を伴 5 肝硬変19例に，UDCA $300 \mathrm{mg}$ 経口負荷試験を行い血清総胆汁酸を酵素学光法 で測定し，種々検討した。結諭：慢性肝疾患全体では, 負荷前值はプロトロンビン時間，アルブミンと逆相関が みられ，負荷後の最高値では，直接型ビリルビンと最す 相関がみられた。各種肝機能検查が異常値を示す割合 
は，負荷後の最高值が $92 \% ，$ 負荷前値が $83 \%$ で，常用肝 機能で最高の異常率を示した ICG 15 分停滞率の $70 \%$ を 大きく上迴り，血清胆汁酸は非常に鋭敏な肝機能検査で あり，乙かも負荷試験を併用すれば，慢性肝疾患の鑑別 あかなり可能である.

\section{3. 肝疾患における 胆汁酸負荷試験の 臨床的} 意義

昭和大学藤が丘病院消化器内科

中神 誠一, 小㷊 明文, 藤田 安幸

山村 光久, 大栗 茂芳, 川瀬 定夫

藤田 力也, 菅田 文夫

各種肝疾患汇経口, 静注胆汁酸負荷を施行し, 常用肝 機能検査との比較, 実験的胆汁らっ滞の胆汁酸動態も含 め, 臨床的意義を検討した，胆计酸測定は真重らの䣼素 法で行なった. 空腹時血中胆汁酸は急性肝炎初期, 非代 償性肝硬変, 肝外胆汁うっ滞で特に高く, 急性, 慢性肝 炎では血清総 Bil と相関したが，肝硬変では解離を示 した. 負荷法では，経口，静注法は，腸疾患の 1 例を除 き相関を示し，特に肝硬変でクリアランスの迤延が著明 であった．実験的胆汁らっ膟モデルでは，胆汁酸と Bil は必ずしも相関を示さなかった，以上より，胆汁酸負荷 試験は肝疾患の鑑別に有用と思われるが，Bil とのギ+ ップなどの原因については推定の城を出ておらず，今後 の検討を要するすのと思われる。

\section{4. 肝疾患における 血中胆汁酸 の 臨床的意義 一酵素法による 空腹時胆汁酸測定とUDCA 負荷試験}

自治医科大学消化器内科

古杉 讓, 野上和加博, 堀口 正彦
田中 昌厷, 吉田 行雄, 関 秀一
井戸 健一, 山中 桓夫, 酒井 秀朗
木村 健
臨床病理部

工藤 快訓, 太田 拔德, 岩田 宏

空腹時胆汁酸は, 正常例 25 例平均 $4.9 \pm 2.3 \mu \mathrm{mol}$, 慢性 肝炎 42 例平均 $10.6 \pm 11.1 \mu \mathrm{mol}$, 肝硬变 63例平均 $32.6 \pm$ $33.9 \mu \mathrm{mol}$ であった. UDCA $300 \mathrm{mg}$ にて経口負荷試験 を行ない，30分值より180分値までの各值より前值を減 しとれらを加えた和を $\Sigma 180$, 同様に $\Sigma 120 ， 180$ 分值より 前値を減じた值を $\Delta 180$ として指栖とした。これら全て
の指標は alb., ch-E， $\gamma$-glo と有意の相関を示した。慢 性肝炎と肝硬变では各指摽の有意差を認め肝硬変, 肝硬 変の初期，慢性肝炎の順に各指標は高值を示した．以上 より UDCA 負荷試験は慢性肝疾患の鑑別に有用な検査 であると思われた。

\section{5. 各種肝疾患にみられる 卵黄負荷前後での 血中総胆汁酸值の变動 \\ 虎の門病院消化器科 \\ 中島 正男，竹内 和男，小宅 映士 \\ 熊田 博光，吉場 朗}

空腹時及び卵黄負荷後の血中総胆汁酸 (SBA) の变動 を健常者 5 例，肝疾患70例で検討した，その結果肝疾患 では，空腹時 SBA が正常であっても卵黄負荷後の SBA が異常となる場合が多かった．空腹時 SBA とArea Under Curve (AUC) との間には強い相関がみられた が，空腹時 SBA ではみられなかった $\mathrm{CH}(2 \mathrm{~A})$ と $\mathrm{CH}$ （2B）及び代償性 LC と非代償性 LC の間の 有意差が AUC ではみられたＬCCでは 3 時間值の下降革延を認 めるものが多かった。 $I C_{R_{15}}$ と空腹時 SBA 及び AUC との間には強い相関がみられた。

各種肝疾患で，卵黄負荷後の内因性胆汁酸值の変動を 測定することは, 単に空腹時 SBA の測定で得られる情 報に比し，肝の病熊を把握する上でより有用と考えられ た.

\section{座長まとめ（49～55) \\ 帝京大学第 1 内科 山中 正己}

近年, 新しい肝機能検查法の一つとして血清胆汁酸の 測定が注目され，空腹時檤の他，内因性预上び外因性胆 汁酸負荷による胆汁酸負荷試験が検討される様になっ た. No. 49は肝疾患時の 空腹時值に関する 集計で No. 50〜55は負荷試験に関するものであり，肝機能検査法と して鋭敏な検査法の一つである事は各演者の一致した見 解であった. No. 49では同一患者，例えば fulminant hepatitis の経過に伴なう值の変動に関しての質問が, No. 51，52では最高值の出現する時間と疾患による peak の漣延の状態と，その意味づけに関して討議が行われ た. No. 52では静脈内投与に伴なら副作用の有無に関し て，また，No. 55では卵黄負荷時の胆霓収縮状態を検討 寸る必要性が論議された. 以上，鋭敏な検查法としての 評価は定まりつつあるが，今後は更に負荷方法，負荷 
量，正常域の設定について意見の統一が行われる事が望 まれる。

\section{6. 肝，胆道疾患における 胆汁酸動態と 肝機} 能検查成績との比較検討

国立横浜東病院内科

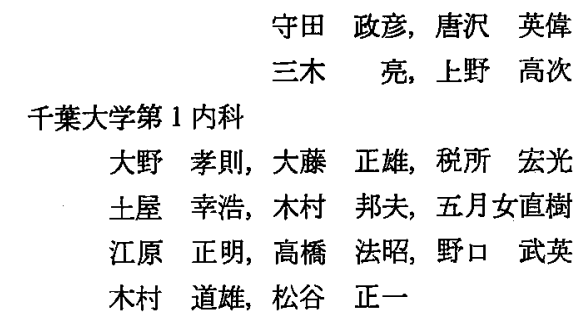

急性肝炎, 肝硬変, 閉塞性黄㾞合計65例に括ける胆汁 並びに血中胆汁酸を測定し各種肝機能検查値との関連に ついて検討した．血清総胆汁酸值は，急性肝炎飞打い て，GOT，GPT，T-bil と相関した. 肝硬变に招いて は，ICG 15分值と相関を認めた．急性肝炎の血清胆汁 酸は GPT，T-bil 等と併行して変動するが，閉塞性黄疸 ドレナージ例ではドレナージ施行後, 血清胆汁酸は Tbil に先行して迅速に正常域へ到達した。䏣汁中胆汁酸 構成比は各疾患で特徵的なパターンを示し，G/T 比は 低值を示したが，急性肝资回復期と閉塞性黄㾞ドレナー シ施行 2 週目には対照に近つくことを認めた。

\section{7. 門脈系静脈血中の総胆汁酸測定}

千葉大学第 1 内科

飯田 真司, 大久保秀樹, 隆 元英

後藤 信昭, 岩間 章介, 武者 広隆 小藤田和郎，奥田 邦雄

今回我々は，経皮経肝門脈カテーテルを利用し，門脈 系静脈 (門脈，上腸間膜静脈，脾静脈）血中の総胆汁酸 溇度を測定した。

対象は，肝硬变症17例である. 総胆汁酸の測定には Sterognost 3 $\alpha$-Automated を用いた。

門脈系静脈血中の胆汁酸濃度は，上腸間膜静脈血が最 も高いものが多数を占めるが，なかと，門脈血，脾静脈 血の濃度が最も高いものもみられた．また，末梢脈血中 濃度は，17例中12例正常に比し高值を示した，さらに， 門脈血中濃度との間には直線的な正の相関がみられた. 肝硬変症で 末梢血中胆汁酸渻度が高值を示す理由とし て, 肝細胞障害とともに肝内外シャントを考光る必要が ある。

\section{8. 肝疾患に対する UDCA 経口負荷試験（R}

\section{IA）の感度と特異性の検討}

北海道大学第 2 内科

篠崎堅次郎，鉡田 吉和，渡辺 正夫

山口彰, 牧野 䰻, 中川 昌一

UDCA $25 \mathrm{mg}$ 経口負荷試験 (RIA) が肝疾患の重症度 を反映することは既に報告したが，今回本試験の 感度 之特異性について空腹時血中総䏣汁酸 (酵素法)，血中 Glycocholic acid (RIA)，食後 2 時間法（醅素法）およ び從来の各種肝機能検査を比較検討した。そその結果，1） UCDA 負荷試験による異常检出率は慢性活動性肝资や 肝硬変でほぼ100\%の高感度を示しいずれの梌查法より も優れ，軽度肝障害の場合は Transaminase のそれに類 似し，食後 2 時間法よりも鋭敏であった，2） UDCA 負 荷試験は従来の肝機能検查法との間に相関がそしくその 特異性が立証された．3）これらの結果は，本 UDCA 試験の投与量が正確でかつ RIA により薬理動態学的 First pass clearance を極めて正確に測定していること に起因すると思われる.

\section{7-Hydroxysteroid dehydrogenase (7-H} SD）による 血清中/次胆汁酸（PBA）濃度測 定とその意義

$\begin{array}{ll}\text { 三宿病院研究検查課 } & \text { 遠藤 了一 } \\ \text { 同 内科野 幸久, 佐藤源一郎 } \\ & \text { 岡部洋太郎, 中島 勉 }\end{array}$

肝，胆道疾患133例，健常対照33例を対象と乙総胆汁 酸 (TBA)，PBA 值之内因性，外因性（UDCA $300 \mathrm{mg}$ 経口負荷）胆汁酸負荷試験に和ける TBA，PBA 檤を測 定した. 内40例は GLC 法で胆洲酸分画を分析した. 肝 硬変とくに非代償期と胆汁らっ滞（肝内，外）で著しく PBA は上昇 (平均 $60 \mu \mathrm{M}$ ) l，PBA/TBA 比が90\%をこ えた（正常 $60 \pm 14 \%$ ). 肝硬変に敌ける PBA の増加は CDCA (70\%強)を主とし胆汁うっ漁では CA (50\%强) を主とするるのであった，また慢性肝疾患に和ける内因 珄胆汁酸負荷試験時の TBA 上昇も PBA を主とするも のが多い，UDCA 負荷試験では，正常対照が主として UDCA の血中增加であるのに対し，肝疾患に打いては PBA 寄与率が高くUDCA 奇与率は $30 \%$ 強であり， 2 次胆汁酸の関与は極めて少なかった。 
60. 血中胆汁酸の微量分画定量

東北大学第 1 外科 木村 睛茂, 高橋 涉 鈴木 籁美, 佐藤 寿雄

眯水性イオン交換ゲル piperidinohydroxypropyl Sephadex LH-20 (PHP-LH-20) に上る分画と醉素法を組みあ わせた微量分画定量法を確立し，肝胆道疾患症例飞応用 し，血中胆汁酸の質的变化について検討を加えた，本法 は $0.5 \mathrm{~m} l$ と少量の血清で正常人レベルまで分画定量で き，かつ再現性，回収率共にすぐれた分析法である．正 常人の総胆汁酸量は平均 $4.7 \mathrm{nmole} / \mathrm{m} l$ で, 遊離型, グリシン抱合型，タゥリン抱合型は各々1.7, 2.1, 0.9 $\mathrm{nmole} / \mathrm{m} l$ で，遊離型の占める比率は $34.5 \%, \mathrm{G} / \mathrm{T}$ 值は 2.7であった. 肝硬変症および閉塞性黄疸症例では総胆 汁酸量は共に增加しているが，遊離型护よび G/T 值は 前者で有意に増加し，血中胆汁酸の増加の機序が異なる ことが推察された。

\section{1. 肝疾患々者での Radioimmunoassay 法} による血中グリココール酸（CG）の測定とそ の評価

福島医科大学第 2 内科

$$
\begin{aligned}
& \text { 村井 隆夫, 䒽藤 孝一, 飯塚 美伸 } \\
& \text { 森藤 隆夫, 吉田 浩, 粕川 礼司 }
\end{aligned}
$$

血中胆汁酸の湘定は鋭钽な肝機能険查法として注目さ れているが， RIA 法による簡便な測定を経験したので 報告する．対象は健常成人 25 例，肝疾患々者 81 例で測定 は Abotte 社の CG-RIA Kitを用いて行った. 健常人

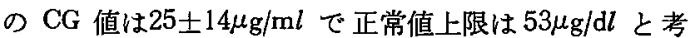
兄られた，血中 $\mathrm{CG}$ 上昇は急性肝炎 $(\mathrm{AH})$, 慢性肝炎 (CH), 肝硬変 (LC) では各々 $38 \% ， 47 \% ， 74 \%$ で認 められ CG 平均值は $794 \mu \mathrm{g} ， 49(\mathrm{CIH}) 484(\mathrm{CAH})$, 1,059であり慢性肝病変では進行度を 反映する傾向を示 し，急性肝病変ではその消長を反映した，通常の肝機能 挨查との対比では GPT 值, 血中 Bil 值, Al-ph, $\mathrm{ICG}_{15}{ }^{\prime}$ 值の㮌に強い正の相関をすべて示した，又他検查法で険 出できなかった肝障害を検出出来た例る多くより鋭敏な 肝機能検査法であり，更に胆汁酸の負荷でその傾向はよ り明白となった。
62. 重症度, 予後, 治療効果判定 のための抱 合胆汁酸測定の意義 北里大学消化器内科

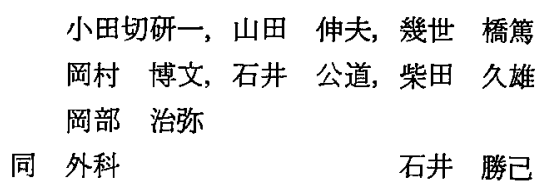

肝胆道疾患に拗ける血清Immunoreactive cholylglycine (CG), Sulfolithocholylglycine (SLCG) をダイナボット 社キットを用い延約1，000回測定，次の結果をえた，1) 䏣石症石灰化例之非石灰化例では，CG と SLCG 值との 比が異なり，ウルソデオキシコール酸投与による石灰化 無効例には CG の上昇がるとめられ，CG/SLCG が大き くなり，胆石溶解例には SLCG の上昇があり CG/SLCG が著しく小さくなった，2）ナイガード社 $3 \alpha$-HSD 用いた虽光法と Radioimmunoassy に上る CG 值との比 较では，慢性肝炎，肝硬変，肝癌では\% CG は高値を示 した.

以上，抱合胆汁酸の測定は，肝胆道疾患に和ける重症 度, 予後, 治療効果判定に有用である.

\section{座長まとめ $(56 \sim 62)$}

北里大学消化器内科柴田 久雄

演題56一62は胆汁酸測定の意義を採血部位，方法の違 いの点等より検討されたるのが多かった．胆汁酸の湘定 及び UDCA 負荷試駼は他の肝機能々異る特異的な面が ある(56，58席).門脈血中でも部位により異り，脾静脈で 高い例の討論がなされた他座長の経験より門脈血が末梢 血上り低い場合のあることがのべられ演者も同様な結果 む見ている (57席)．最近 $7 \alpha \mathrm{HSD}$ を用いる一次胆汁酸 の測定が報告され今後ルーチンに実施可能な分画測定に 向うものと思われた（59席）.

又 PHPLH20による抱合胆汁酸の 微量分画湘定が 報 告され，G/T 比が微量から容易に出来るとのべられた (60席).

RIA に上る抱含胆汁酸の測定も最近広く行われるよ らになったが cholylglycine (CG) が肝疾患で進行度を 反映すること（61席）及び UDCA の長期負荷の抱合 胆汁酸への影響及びこれの瀶床応用につき報告された (62席). 
63. 肝外性閉塞性黄㾝を呈した 潜在性 Hodgkin 氏病 (Stage IV) の 1 例

日本大学第 1 病理 柄沢 勉, 志力 俊夫 阿部 賢治, 高島 宏幸

原因不明の発熱のため入院精査中，高度の閉塞性黄瘟 をきたし，剖検により肝門部の Hodgkin 氏病 (lymphocyte depletion type) による閉塞性黄疸と判明した症例 を報告する，剖検時 Hodgkin 氏病は stageIVであった が，最も高度な浸潤部位は肝門部であった，生学および 剖検時表在性リンパ節腫脹は無かったが，剖検時，最大 径 $2 \mathrm{~mm}$ の頝部表在リンパ節 1 個に Hodgkin 氏病を認 わた. Hodgkin 氏病に括ける胆汁らっ滞症は, 比較的上 く知られているが，Hodgkin 氏病肝門型ともいうべき特 異な病像を呈した点と，腫脹の無い極小表在リンパ節に 他の病変部と同様の型の Hodgkin 氏病を認めた点は興 味あり，かつ重要な所見であるので報告する.

\section{4. 高度の GOT 上昇を示した循環障害によ} る肝障害

日本医科大学第 1 内科 赤池 正博, 佐々木熙之, 鈴木 健 荒牧 㙇己，奥村 英正

同 CCU 松川フレディ, 高野照夫 大林 完二

症例は51歳男. 37歳の時血清肝炎に罹患. 昭和52年 1 月24日午後 10 時, 急性心筋梗塞の発作要り某病院に入院. ショックとなったため 1 月26日本院 CCU に収容. 收容 時意識清明, 血压128/84, 肝触れず，肺肝境界は第 6 肋 間. A-V ブロックを伴なら後壁梗塞であった. GOT 19,400, GPT 1,150, GOT/GPT 16.9, CPK 1,840 T.B. $0.6 \mathrm{mg} / \mathrm{d} l$ と著明な $\mathrm{GOT}, \mathrm{CPK}$ 上昇と GOT， GPT の 解離を及た. GOT, GPT は30病日には正常化し退院し た. 36病日の肝生検では軽度のうっ血と肝小葉中心性壊 死の存在を認めた. 文献上, このような GOT の高値を きたした報告はまれで，かつ通常このよう高值を呈す る例は死亡するものと考克られるが，本例は回復した。

\section{5. 高度の黄疸を呈し短期間で 死亡したアミ ロイドーシスの 1 剖検例 北里大学病理相田 尚文, 五十首正広 中 英男, 奥平 雅彦}

症例は，43歳，女性. 本年 4 月初旬上り浮腫，乏尿出 琴. 近医にて加療を受けたが軽快せず，むしる增悪した
為，6月 2 日当院に転院. 腎機能不全及び Al-P，LAP， $\gamma$-GTP, LDH 等が異常高値を示していた。直ちに血液 透析を開始したが，黄疸が発現し，急速に增強. 6 月15 日死亡. 5 月中旬の腎シンチでは，腎造影は薄く，朋， 脾, 骨䯣炑取込を見た. 約 3 週後の肝シンチでは, 肝, 脾，骨髄は造影されず，肺に集積像を見た，剖検時，黄 疸と大量の胸腹水があり, 肝, 脾は硬く腫大. 組織学的 には，高度なアミロイドの沈着を見た，その他，腎，副 腎，骨髄、リンパ節にもアミロイドの沈着を認めた。剖 検所見上り基礎疾患之思われる病変は認められなかっ た.

66. 肝内胆汁うっ滞を示した赤白血病の 1 例 東京大学第 3 内科

池淵 研二，佐藤 弘，岩崎 泰彦 浦部 晶夫，井趈 道夫，森 真由美

橋本 康男, 大久保昭行, 小坟 樹徳

38藏女性. 現病歴：1978年 9 月より耳後部痛，頓部瘇 脹，発熱，不正出血，胸痛出現。1979年 2 月，骨髄穿刺 にて白血病题い，現症：頻拍，微熱，1横指の肝腫大. 倹查所見: 白血球 10,300 ，骨䯣芽球 $9 \%$ ，赤芽球 $35 / 100$ $\mathrm{WBC}$, 特殊染色飞て赤白血病之婄断. 経過 : 第 8 クール 時, GPT $1,275 \mathrm{u} / l$, ALP $390 \mathrm{u} / l, \gamma$-GTP $630 \mathrm{u} / l$, , T.Bil $25.5 \mathrm{mg} / \mathrm{d} l$ (D. Bil 20.5)，第 9 クール時，GPT 490, ALP 178, $\gamma$-GTP 65, T. Bil 23.5 (D.Bil 23.5) と 2 回の胆汁らっ漁を示すが，いずれる白血病細胞の減少と 共に軽快. 第 9 クール飞先行して重篤な低燐血症(く $1 \mathrm{mg} / \mathrm{d} l)$ が存在. 考按 : 白血病細胞浸潤と胆汁うっ滞の 関係，黄㾞增強に比して胆道系酵素が低值傾向を示した ことと，合併した低燐血症がどう関係するかなど，興味 ある経過をたどった。

\section{7. $r$-GTP 上昇のみられない肝内胆汁うっ滞 を示した多発性筋炎症例 福島医科大学第 2 内科 佐久間博史, 宮田 昌之, 矢吹 孝志 服部 好伸, 西間木友衛, 森藤 隆夫 村井隆夫, 吉田 浩, 粕川 礼司}

症例 : 55歳 男. 家族歴 (-). 既往歷 (-).

昭和53年 4 月，粗大力低下を主訴比入院。CPK ・ 尿 クレアチン排泄値上昇, EMG で myogenic pattern 等 より多発性筋炎（疑），退院後. 外来で副皮ス剂（維持 
量）と蛋白同化ステロイド（蛋同剂）等で加療. 54 年 3 月下旬，全身僚总感，発黄がみられ，4 月再入院. 軽度 黄㾝・粗大力低下 - 肝部の打痛以外は著変なし. 倹查成 績で GOT・GPT 軽度上昇, Al-P $39.7 \mathrm{KAU}, \mathrm{LAP}$ $467 \mathrm{GRU}$ と上昇するす $\gamma \mathrm{GTP} 44 \mathrm{mU} / \mathrm{m} l$. 尿クレアチ ン, 血糖， $\alpha_{2}^{-}, \beta-, \gamma-\mathrm{gl}$ I IgA ・ M, TTT 上暑, ICG 16.7 $\%, \mathrm{RF}(+)$, 自己抗体 ( $(-)$. 肝生検像で肝内胆汁 弓 っ滞を認め，グ鞘・類洞内の变化 $(-)$ ，起因因子之考 えられる蛋同剤中止，副皮ス剤増量で改善，全観察期間 中, $\gamma \mathrm{GTP}$ 值は正常域にあった。

\section{座長まとめ（63～67）}

\section{北里大学病理}

佐々木憲一

63席 Hodgkin 病例飞対し肝門部病変 (肝内門脈樹) の程度に比し，黄疸発現時期で漣い印象があるとの付議 がありこの例の組織型 (lymphocyte depletion type) から進展の速度との関連が 考学られる. 64席 ischemic necrosis の S-GOT.S-GPT 上昇とその比が大である点 は肝門醭素分布々関係するとの発表で，追加発現が数個 所の施設からあった．東大小児科（平木）上り左心形成 不全症候群等の心奇形でもかかる報告が増加していると の追加があった。

65席アミロイド症に，同様の 黄疸発生例の 追加があ り，黄疸発現機序の討論があった，本例では末梢門脈域 に可成り目立ったアミロイド沈着があり，元細胆管より 小葉間胆管への流通障害が考号られ，更に末期循環障害 因子も加味されているものと考党られる.

66席・67席は胆汁与っ滞と AI-P，LAP の上昇があっ たにもかかわらず， $\gamma$-GTPが低值を示した例（66席は特 K一過性）で， $\gamma$-GTP低值関して低P 血症を中心とし た討議が行われた。

68.放射線照射により高度の肝障害を起こし た症例

旭川医科大学第 3 内科

$$
\begin{aligned}
& \text { 富永 吉春, 関谷 千寻, 矢崎 康幸 } \\
& \text { 沼崎 彰，棍政，高橋 篤 }
\end{aligned}
$$$$
\text { 高杉 佑一，並木 正義 }
$$

症例は49歳の男性で，食道癌のため，本学放射線科に て，昭和53年 6 月30日より 8 月 8 日まで放射線照射を受 けたが，そのうち，4,000 rads の照射野が肝左葉を含ん でいた。同 8 月下旬よりトランスフミナーぜの中等度上 界をみた。肝シンチグラムでは，入院時正常であった朋
左葉が欠損していた，腹垫鏡検相でみると，肝左葉のみ 暗褐色で，全体に薄くなっており，強い線維増生が疑わ れる所見であった，同部の生検でむ肝実質は島状に残存 のみであり，すべて線維組織におきかわっていた，放射 する線照射により肝障害が生ずることは知られており， 若干の考察を加壳て報告した.

\section{9. 門脈圧え進症を 呈した 肝サルコイドーシ} スの二症例

千葉大学第 1 内科 後藤 信昭，大西久化彦，武者 広隆 小藤田和郎, 奥田 邦雄

門脈圧九進症を呈した肝サルコイドーシスの二症例を 報告する．症例 1 は29歳の女性で腹水を主訴に入院した か，肝重，巨脾，組班，肺病変，溶血性貧血飞上ると思 われる黄疾を伴なっていた。 な打本症例の肝は分葉肝状 を呈していた，症例 2 は58歳の女性で皮凬科でサルコイ ドーシスと診断され肝精査を目的に紹介されたが，脾 瘇，腹壁静脈怒張，著明な食道胃静脈瘤，紅斑，肺病変 がみられた，両症例とも肝生検でサルコイド結節と著明 な線維化が認められた，経皮経肝門脈造影における門脈 圧はそれ先れ $356 \mathrm{mmH}_{2} \mathrm{O} ， 245 \mathrm{mmH}_{2} \mathrm{O}$ で明らかな上上 昇がみられたが，閉塞肝静脈压は $170 \mathrm{mmH}_{2} \mathrm{O}, 110 \mathrm{~mm}$ $\mathrm{H}_{2} \mathrm{O}$ であった．門脈像で症例 2 に著しい副血行路の発 達がみられ。

\section{0. 多核巨細胞を含む hepatic granuloma} の 3 例

東京女子医科大学消化器病センター

林 直諒，久満 董樹，本池 洋二 奥田 博明，小幡 裕 同 心臟血厌研究所

九段坟病院眼科

関口 守衛，沼尾 嘉時 小林 フミ

第 1 例，49歳男性. 慢性肝炎として加療をらけたが精 査の為入院. 肝生検で Lang hans type の巨細胞を含む granuloma をみとめた，心，眼科的所見からサルコイド ーシスと診断した．第 2 例，52墄主婦，貧血 肝脾嗹あ り，Banti 症候群と診断され脾摘術をらけたが，3年後 食道静脈癉出血あり，再手術. 生検所見では多核巨細胞 を含む granuloma あり，組織所見，抗ミトコンドリフ 抗体陽性で PBC，之診断 Lた。第 3 例，59歳主婦，肝内 結石で手術. 肝組織内の多数の granuloma おり, ッ反, 
頝部リンパ腫結核, 胸膜炎再発等, 結核性 granuloma 思われた。

\section{1. 高シトルリン血症の 1 例 \\ 信州大学第 2 内科

鈴木 陽一, 長田 敦夫, 清沢 研道
赤羽 賢浩, 小池ゆり子, 山村 伸吉
中谷 均, 田中 栄司, 上条 賢介
川原健治郎, 古田 精市

症例，26歳女，22歳時より意識消失を含む意識障害を 反復するため精查のため当科入院. 幼少時よりピーナ ッ, タコ，イカ等を好む偏食あり．発作時に $500 \mu \mathrm{g} / \mathrm{d} l$ 前後の高アンモニア血症と脳波上 slow $\alpha . \theta . \delta$. 三相波を 見た.䀒機能検查では，T.P.6-5とやや低下であるがICG を含め正常であった，肝は組織学的に 軽度脂肪沈着と hepatic fibrosis であり，腹部血管造影にてシャントは 否定され, 血清, 尿, 檤液のアミノ酸分析にて, シトル リンの増加（正常の約 4 倍）を誌めた。外科的生検肝組 轼にて尿素サイクル醅素を測定したところ，アルギニノ コハク酸合成酵素の約 $2 / 3 の$ 低下を認め，現在のところ 醭素蛋白量の減少によると思われる. 以上成人型高シト ルリン血症の一例を報告した.

\section{2. 慢性肝炎の組織像を示したI 型糖原病の 1} 例

\section{東北大学第 3 内科 \\ 石井 元康, 太田 慎一, 清水 章 鈴木 勃志, 大梘 昌夫, 後藤 由夫}

28歳の男子で肝腫大, 鼻出血を主訴に入院, 開腹生検に より糖原病 I a 型と確診した. 出血㑯向については, in vitro の検查で血小板 von willebrand 因子 receptor の異常を示唆する結果が出た. 肝については, 同じリ゙リ コーゲン沈着と低血糖をきたす acquired form としての Insulinoma の肝と, genetic disorder の例としての本例 を電䫓で比較観察したら， s-ER の Vesiculation, Disse 腔, BC に面した microvilli の減少, BC の払大（黄㾝 はない)が認められ， genetic disorder と，血小板と 肝の膜の変化の関連を示唆する. まだ゙リコーゲンを Silver-protein を用いて染色すると，クリコーダンのネ ガティブ染色とほぼ同様の像が得られ，本染色により 本症例の細胞質内グリコーゲンは $\alpha$-particle で核内は $\beta$-particle の形で存在すると思われる.
座長まとめ $(68 \sim 72)$

$$
\text { 東京莪信病院 }
$$

兼高 達式

68 : 食道癌に対し放射線療法を行ない, 肝左葉のマル シャンタイプの肝填死を起こした興味ある症例の提示で あった. アルコールが若干影響を与えているか，薬物の 関与はない.

69 : 肝サルコイドーシスは，一般に軽症であるが，本 例はかなり高度な門脈圧九進を含む障害があった点が注 目される.

70 : サルコイドーシス, PBC, Tbc による 3 例の hepatic granuloma の提示があった. 組織学的に詳しく検 討されている.

71 : 尿素サイクル代謝異常があり，シトルリンが正常 上昇の 4 倍となった症例の提示があった.アミノ酸分析 をはじめ詳細に検討された興味ある例である.

72 ：成人にみられた I 型糖原病の症例提示である. 肝 組織像は慢性肝炎様であった。

全体として，興味のある症例を，詳細に検討したニニ ークな発表であった。

\section{3. 直接 ビルリビン血症を伴った ICG 排泄 異常症の一例 \\ 福島県立医科大学第 2 内科 \\ 斉藤 孝一，作田百合子，森藤 隆夫 村井 隆夫, 吉田浩, 粕川 礼司 福自県立医科大学第 1 病理 内藤真}

症例 : 28歳男性, 会社員. 主訴 : 黄㾝. 家族厢 : 肝蔵 癌, 胃癌で死亡. 現病歴: 下痵・咽頭痛, 寒気出現, そ の 3 日後黄㾞を指摘. 入院時: 眼結膜に軽度黄疸, 検査 で t-bil， dir-bil の上昇，醉素・賿質は異常なし， R ICG $90 \%$ 以上 $\mathbf{R}_{\mathrm{BSP} 45} 1.5 \%$ と解離. $\mathrm{a}: 0.014, \mathrm{~b}: 0.012$, h : 0.002. 胆䂠造影正常, 腹腔鏡検查 : 著変なL. 肝生 検組織 H.E 染色像 : non-specific reaction. 電影像 : 肝細胞内に mithochondria の尰大, paracrystelline 封 入体, lipofuscin 様物質の沈着. Kupffer cell 内にb lipofuscin 様物質の沈着. 家族榆查で父親に tot-bil, dir-bilの增加. $\mathbf{R}_{\mathrm{ICG}_{15}}$ の上昇， $\mathbf{R}_{\mathrm{BSP}_{45}}$ の軽度上昇，再 上昇 (一), 肝組織像, fatty liver. 電颢像 : lipofuscin 様物質の沈着. 家族内発生が寲われた。 
$142: 940$

訮

臟

74. 妊娠に伴って 発黄した 肝内胆汁うっ滞症 の 1 例

順天堂大学内科消化器

宮村 拓郎，北見 啓之，黑田 博之

山口 毅一, 浪久 利彦

今回われわれは妊娠中に発黄した症例について，その 病因を考察する上で示唆に富むいくつかの経験をしたの で報告する．症例は31歳の初妊婦で貧血のため鉄剤の注 射を受けていたが，妊娠 3 ケ月目に全身瘦痒感出現，妊 娠 5 ケ月目に黄㡺を指摘され入院した。軽度の肝腫大を 認め，肝機能検査ではトランスフミナーゼの軽度上昇 と，胆管系酵素，血清ビリルビン值の上昇が，人工分婏 後䄪 2 ケ月をで持続した. 抗ミトコンドリア抗体が陽性 で,リンパ球刺激試験では，鉄剂，エストリオールに寲 陽性を示した. 発黄後の 9 週目，23週目の肝生検像はい ず㧈䏣汁らっ滞珄肝炎であった。本例はその経過か ら，妊娠性反復性黄疾とはいい難く，過敏性肝障害が疑 われるが，原発性胆汁性肝硬変の初期像む完全には否定 できなかった。

\section{5. 肝表在リンパ管の 正常構築およびその 流} 路

北里大学病理北爪 伸仁, 相田 尚文 佐々木㥶一, 奥平 雅彦

北里大学剖検例48例の肝蔵につき, 表在リンパ管を確 保し，バリウムなどを注入して観察した.リンパ管の個 々の肝小葉表面は数個〜十数個の毛細りンパ管ループか らなる微細なりンパ管の網目によって覆われている. 毛 細リンパ管は細リンパ幹に集をり，蛇行状走行を示すリ ンパ本幹に流入する，リンパ本幹は訮右葉横隔面では右 三㞣勒帯，肝鎌状鞄帯に流出し，左葉では線維附属，左 三角靶帯，肝鏮状靱帯に流出する，肝缄蔵側面では，左 葉, 右葉, 方形葉, 胆の5，尾状葉の 1 部，肝横隔面右 葉の 1 部はすべて肝門部に流出し，右葉の 1 部之尾状葉 の 1 部は横隔膜附着部に流出する. 表在りンパ管は被膜 血管と同様に深部リンパ管と密に連絡している，また表 在リンパ管は肝表面動脈枝之並行的に走行し太い動脈枝 はリンパ幹及びその枝により四絖され，リンパ本幹は細 い動脈枝の囲䌇を受けている。

21 巻 7 号 (1980)

76. HBs 抗原キァリアー陰性化の諸因子 三井記念病院消化器センター内科

鵢沼 直雄, 郭伸, 林田 憲正

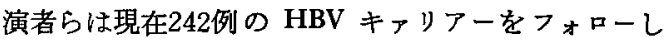
ている.内訳は男151例，女91例であり，男が多い，年 㱓分布では男女ともに20〜30歳にピークがあるが，年龄 の上昇につれて女は急速に減少する. 肝機能正常者は 137例で50\%，慢性肝炎 $22 \% ，$ 肝硬変 $10 \%$ ，肝癌11\%で これらの慢性肝疾患は男に多かった. 症例34歳, 女. 肝 機能正常の $\mathrm{HBV} キ$ キアーで第 1 子もキャリアーであ る. 特別な誘因なく急性発症し GOT 1,200, GPT 500 を示し， HBs 抗原は $2 \geqq^{12}$ 力ら陰性化， HBs 抗体陰 性から $2 \geqq^{6}$ となった. $\mathrm{HBc}$ 抗体は $2 \geqq^{12} か ら ら 2^{10}$ と尚 高い. その他 5 例に扣いて HBs 抗原が陰性化したが， HBs 抗体は尚陰性， HBc 抗体価は高いので low titer 化と考える. それらの陰性化諸因子は輸血，インフルエ ンザ, 肝癌の末期等であった.

\section{7. 脂肪肝における 色素排泄異常の 形態学的 基礎の検討}

東海大学第 3 内科 稲葉 允，岩村健一郎

脂肪肝に拈ける ICG および BSP 排泄遅延の解離例 における形態学的美異の有無を目的として, 両色素排泄 の解離がみとめられた脂肪肝107例の生検の光顕的なら びに電顕的解析を゙行なった，高度脂肪化例中 ICG 排泄 遅延は症例の34\%，BSP 排泄遅延は90.5\%に認められ た. ICG 異常例は主に類洞壁細胞の膜様変化，PORE の消失，DISSE 腔内細絧線維束の增加など肝血流障害に 関連し，BSP 途延例は肝細胞内系粒体の膨化・変形和 よび粗面小胞体の数の減少や滑面小胞体の変形等, 小胞 器官の形態変化，したがって機能の変化と脂肪化の程度 に相関が示された. 一方，胆管周用小器官であるライン ゾームやゴルジ装置等に明確な変化はみとめられなかっ た.

\section{座長まとめ（73～77）}

鉄道中央病院

南部 勝司

73席は，直接型ビリルビン血症に ICG の高度異常を 伴なった症例であるが，父親にす高ビリルビン血症と ICG 高度異常を認めた興味ある症例である。74席は, 妊娠に伴なって発黄した症例で，妊娠性反復性肝内䏣 汁うっ滞とは経過がやや異なっており，その病因につい 
ての討論が行なわれた. 75席は, 䀒表在リンパ管の正常 棈筑とその流路についての報告である. 病態肝での追究 が期待された. 76席では，HBs 抗原キァリアーで，肝 炎の急性発症後, インフルェンザ䍜患後, 輸血後, 肝癌 の末期などで HBs 抗原が陰性化した症例が 提示され た. 77席は, 脂肪肝におけ、る色素排泄異常と形態学的所 見の関係についての報告である. BSP 異常例之 ICG 異 常例とでは電顕所見に差があるとの発表であったが，そ のような差はICGとBSPによる差ではなく，負荷量 による差ではないか，との質問があった。

\section{8. ウイルス肝焱の肝外症状の検討} 埼玉医科大学第 1 内科

永島 成晃, 畔柳 武雄

当科の過去 7 年間のウイルス性肝炎患者64例の自他覚 症状及び検查所見等を検討した，消化器症状と感冒症状 が多く，他に皮〉発疹, 薬物過敏症, 色素沈着, 鼻出血及 び紫斑が若干みられた，検査所見では一過性の軽微な蛋 白尿 $31.3 \%$ ，軽微な顕微鏡的血尿 $9.4 \%$ ，溶血を示唆す る軽度の貧血 $20.3 \%$, 異型リンパ球 $18.8 \%$, target cell $9.4 \%$ ，赤血球大小不同 $6.3 \%$ ，他に好酸球增加，好塩基 球増加, 単球増加, 相対的リンパ球増加及び白血球数減 少も一部にみられた. 皮フ病変, 腎葴所見及び血液学的 異常等よりウイルス性肝炎が肝に限局しない全身的な病 变であると考えられる. 皮フ発疹，関節痛，発熱，腎炎 様所見を呈するものの一部には immune complex の関 与するものもあるようた。

\section{9. 当院で経験した HBs 抗原陽性者の腎障害} 県立岐.帛病院内科

$\begin{array}{lrr}\text { 広瀬 洋, 小島 } & \text { 嵙雄, 福田 } & \text { 信臣 } \\ \text { 足立 信幸, 青山 } & \text { 政史, 小林 } & \text { 成禎 } \\ \text { 大島健次郎 } & & \\ \text { 小児科 } & \text { 田中 } & \text { 浩 } \\ \text { 険查科 } & \text { 笹岡 } & \text { 郁乎 }\end{array}$

我々が経験した HBsAg (十) 尿蛋白異常者は成人 7 例 $[\mathrm{HBeAg}(+) 5 / 7, \mathrm{HBeAbl} / 7]$ で腎生検にて membronous gl. nephritis 2 例, mesangio proliferatine gl. nephritis 1 例であった. 成人一般肝外来での尿蛋白井以 上は HBsAg (+)2/71, HBsAg (-)2/86, HBsAg (-) ドック群83/14,579, HBsAg (一)一般外来5/231であっ た. 小児腎外来53例中 HBsAg (+) 7 例 $[\mathrm{HBeAg}(+)$
4/7, $\mathrm{HBeAb}(+)$ 2/7] で尿蛋白H以上 $\mathrm{HBsAg}(+)$ 5/7,HBsAg（一）16/46であった. 腎外来を除く小児 HBsAg (十) の尿蛋白異常は 7 例 $[\mathrm{HBeAg}(+) 4 / 7, \mathrm{HBe}$ $\mathrm{Ab}(+) 2 / 7$ でした. したがって小児の尿蛋白H以上は HBsAg (+)9/60であるのに HBsAg (一) 一般外来6/203 と少なかった。成人 $\mathrm{HBe}$ 抗原（血中）陽性 1 例に蛍 光抗体法により腎系球体基底膜 $\mathrm{HBeAg} \not ゙$ granulor に沈着を示したが，HBs 抗原は証明し支なかった。

\section{0. 浮腫と血管资を伴った $\mathbf{B}$ 型肝资の 1 例} 東京厚生年金病院内科

東 英敬, 井野 元勤
宝 角衛, 福永 進

倦怠感と関節痛で発症, 蛋白尿, 高血圧 浮腫を一過 性に認め，両下肢に䩑痒感と圧痛を伴ら皮疹が出現した 72歳男の急性 B 型肝炎を経験した。 HBsAg は2 月月後 陰性化, GOT, GPT \& 2 ケ月後ピークに達した後漸減 正常化. 黄疾なし. 皮疮は点状小紫斑と紅色小丘疮で浮 尰とかゆみと痛を伴い，組織学的には真皮下層の中～ 小動脈の管胿狭少化，内皮細胞の腫大，配列の乱れあ り，壁は膨化肥厚，fibrinoid deposition が不規則にあ る. 外膜を含めた血管周囲に毛細血管増生と組織球，リ ンパ球などの唚出をみとめた. Gianotti 病とは発疹の形 態，組織学的病変の場に違いがある．本例は一過性腎障 害, 関節痛, 血管炎等より HBsAg-Ab immune complex の関与が考えられるが，この点, Gocke の血管炎と比較 しても fibrinoid deposition など共通点が多い.

\section{HBs 抗原陽性例亡陰性例 のタンパク尿の 出現頻度の検討 虎の門病院消化器科 \\ 熊田 博光, 小宅 映士, 竹内 和男 中島 正男, 吉場 朗 \\ 同 病理学科遠藤 雄三, 原 満}

近年, HBs 抗原とタンパク尿との関係について, 多 くの報告がなされている. 今回我々は過去 2 年間に, 肝 生検或いは，剖検により診断を確定した慢性肝炎，肝 硬変213例について，頻回に尿タンパクを测定した所， HBs 抗原陽性例47例では，10例（21.3\%）に尿タンパ クが認められた. 一方 HBs 抗原陰性例166例では 2 例 (1.2\%) 下尿タンパクが梕められた. 又 $\mathrm{HBe}$ 抗原 HBe 抗体系では，肝硬变が多かったためか，10例中 9 
例が HBe 抗体が陽性であった，腎生検例では，6例中 4 例が，膜性増殖性腎炎で，2 例は，膜性腎炎であっ た.

82. 早期に 著しい堅不全を伴い 血液透析等に より治痣した劇症肝焱の一例 北里大学内科

真玉寿美生，八島 良和，中沢 秀昭 山田 伸夫, 石井 公道, 柴田 久雄 岡部 治弥

同 病理 相田 尚文

症例は 36歳男性. 昭和54年 2 月下旬全身倦䓌感で発 症. 2 月25日発黄. 26日他院入院. BUN 38.1. 28日当 院内科転院. 転院時 T.B. 9.5, GOT 3,355単位, GPT 2,445単位, LDH 2,526単位, BUN 97, CRTN 9.0, HBs 抗原陰性と, 劇症型肝炎と急性腎不全を呈した。 第1病日にはすでに無尿となり，腹膜潅流，血液透析 (11回), チャコールによる hemoperfusion, 交換輸血 (3回) を施行. 発症一ヶ月にして利杘期に入り, 透析 離脱ができた．本院20例の劇症肝炎の検討で，他に，高 クレアチニン血症を呈したものは，4例あるが，本例の 如く早期腎不全をるって発症するのは特異であり，尿 所見にて, 蛋白 (一), 血尿(一), 円柱 (一) より, 腎 血管の spasm による虚血が肝腎症候群を招来したもの と思われる。

座長まとめ（78～82）

東京厚生年金病院内科福永進 この5題の発表の中ではウイルス肝炎の肝外症状のう ち，腎障害が最も多く論議され，他に血液像，皮つ発疹 等が検討された．78席は肝外症状は広汎に分析，ことに 異型リンパ球出現より免疫系の関与を考察したが，この 点で B と非B間に差は認めなかった，79席は主に小児 の腎障害例を検討した。成人の場合 HBs 抗原抗体免疫 複合体の亲球体基底膜沈着が問題となるが，免度機構未 成熟の 小児の 場合の 蛋白尿の 原因は興味あるところで ある.やはり Bは非Bより腎障害例が多かった. 又 抗体陽性例 2 例を認めたことは, 既に Seroconversion が起りらる事を示し，免疫機構の関与の点から注目され る. 81席は慢性肝炎と肝硬変症に対象をしぼったが，蛋 白尿はBが非 B より王倒的に多い事を示し，又生検組織 像は HBs 抗原抗体免疫複合体の関与を示唆する膜性又 は膜性糸球体腎炎であった. 最後に82席の無尿の劇症肝
炎を人工肝等あらゆる手段で救命された報告に敬意を表 したい.

\section{3. ウイルス肝炎に伴う末梢神経障害} 東京慈恵会医科大学第 1 内科

$$
\begin{aligned}
& \text { 唐木 正敏, 竹内 正 } \\
& \text { 比嘉 康宏, 亀田 治男 }
\end{aligned}
$$

急性肝炎に伴う末梢神経障害について臨床的, 電気生 理学的検討を行ない，西方せて慢性肝资と対比検討し た. 対象は急性肝炎25例，慢性肝炎50例である。

(1) 自覚症状としては，限局性糼疼弯，異常知覚，自 発性筋肉痛，四肢脱力感などを慢性肝炎では52\%に認め たが，急性肝炎では24\%と少なく一過性のものが多かっ た. (2) 他覚所見では筋伸展反射，振動覚，知覚などに 異常を18\%に認めた，(3) 㬳電図異常は慢性肝炎に比し 急性肝炎で有意に少なかった，(4) 末梢神経伝導速度は 全例正常範囲内であった.

以上慢性所炎にはしばしば末梢神経障害がみられ注意 を要すると考えられる。

\section{4. 脳症状を主訴とした HBs 抗原陽性若年} 性肝硬変の 1 例

国立相模原病院内科

沓掛 伸二, 本間 定，加藤由美子

村山正昭, 安部 明郎, 島野毅八郎

東京派信病院消化器科兼高 達式

症例 : 28歳, 男, 会社員 1975年 大学卒業後 毎日大 酒，文章の内容の理解不能を主訴に受診，来院時の文章 の理解力, 計算力は小学 1 年生程度, 手術, 黄疾の既往 はないが，現在 HBs抗体陽性の母親より輸血を受けたこ とあり．入院後低蛋白食，ラクッロースの投与などによ り軽快退院, しかし高アンモニア血症, 全般に Slow wave で，後頭に三相波が多数出現する脳波の異常，エンドト キシン血症などは改善はするが，正常化はしなかった。 検查成續では，HBs 抗原陽性，HBe 抗原抗体はともに 陰性，腹腔鏡下に腹壁静脈の怒張と巨大な脾腫を伴う肝 硬変を認めた，脳症状を主訴とした $\mathrm{HBe}$ 抗原陽性の若 年性肝硬変の 1 例として若干の考察を加えて発表した。 
85. 末梢単神経炎症状を主訴として 発症した 急性 B 型肝炎の 1 例

信州大学第 2 内科

三浦 正澄，村山 伸介，小松 敬直 小池ゆり子，川原健治郎，赤羽 賢浩

清沢 研道, 長田 敦夫, 古田 精市

症例は32歳男，透析勤務医，昭和53年 2 月 15 日，頭皮 の Paresthesia，激しい頭痛，高熱出泏現，蛋白尿，関節 痛も伴い，2 日後黄瘨, 消化器症状も出現した. 肝機能 検査で, GOT 5,480 GPT 5,370, LDH 3,798. T.Bil $2.3 \mathrm{chol} 116 \mathrm{NH}_{3} 248(100 \sim 150)$ Thrombotest $16 \%$ と 高度異常を認ぬた。肝は右乳線上 2 横指，圧痛を伴亏弾

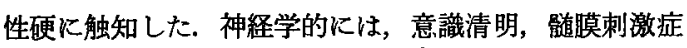
状なく，䯣液検査でも正常，後頭部から頭頂部にかけて の paresthesia を認め, 後頭神経単神経桨として Block 施行後，頭部症状は改善した，反射は全般にやや低下 したが，その他，筋力, 感覚障害等はなかった. 経過中 HBs抗原抗体は常に陰性, anti HBc 抗体価 (IAHA) か 初期 $2^{3}$ が回復期 $2^{12}$ と上昇し, 本症例は急性 B 型肝资 である診断した。

86. 劇症・垔急性肝焱時の膵病変について 信州大学第 2 内科

今井 俊輔, 長田 敦夫, 清沢 研道 赤羽 賢浩, 宣保 行雄, 村山 伸介 野沢 敬一，小池以り子，古田 精市

劇症, 亜急性肝资時飞各々膵㙹死を認めた 2 症例を呈

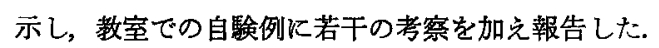

高フミラーで血症は，劇症・重急性肝炎例で $34.8 \%$ 亿 みられ，通常の経過をとる急性肝炎例では6.3\%であり， 前者化有意心高率たった。しかし劇症・亜急性肝炎剖倹 例では高アミラーぜ血症を示した例です膆䘫死のみられ ない例もあり，䐗炎合併の他腎不全その他の影響る考 えられる. 劇症肝桨に合併する脺资の原因は種々考点ら れているが, 症例 1 では D.I.C.の影響も否定できず, 症例 2 では長い、领酒歴が慢性脺炎に関与し, 急性増悪に は長期ステロイド投与あるいはそれによるサイトメガロ ウイルス感染も関係あるかもしれない。
87. 慢性肝炎例に於ける脾腫 の意義について の検討

東京大学第 2 内科

\begin{tabular}{|c|c|c|c|c|}
\hline 本木 & 達也, 片本 & 哲郎, & 稲垣 & \\
\hline 岡野 & 健一, 平野 & 正㶳, & 寺野 & \\
\hline 松本 & $\begin{array}{l}\text { 和則, 神坂 } \\
\text { 覚 }\end{array}$ & 和明, & 上井 & \\
\hline & 科 & & 森成 & \\
\hline & & & 大野 & \\
\hline
\end{tabular}

対象之方法: 当科の慢性肝炎入院例中, 肝脾共に良く

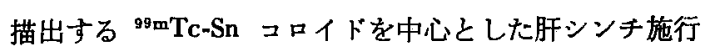
例について, (A) 脾長径, (B) 脾長径/肝右葉最大 径の比，(C) 脾黑化度を測定して臨床所見との関係に ついて検討した。（成績と考察）(1) 慢性肝炎では肝硬 変に少るが脾腫と脾掑取増加を示す，(2) 本症の脾腫の 程度は肝炎の活動性と相関し，肝機能では IgG，TTT, $\mathrm{ZnTT}, \mathrm{RA}$ と相関する. ICGR $_{15}$, GOT, GPT などとは 相関しない. (3) 脾腫が進んだ例では血小板減少など脾 機能六進を思わせる所見を呈する例がある. (4)，脾の黒 化度の推移と肝硬变への移行は必ずしる平行せず，また 現時点での脾黑化度の程度から肝硬変への進展の可能性 は予測できない。

\section{座長まとめ (83〜87)}

国立相模原病院

島野毅入郎

83席と85席はウイルス性肝炎における末梢神経障害の 閣題を取り扱っている. 急性肝炎では慢性肝炎程多くは ないが，39\%にみられ一過性のものが多い，原因として はゥイルスの直接, 神経侵襲も考兄られるし，自己兔 疫, 代謝障害の可能性もあり今後の検討にまつ.85席は 後頭神絓痛の形ができたと考克られ，肝炎関係では下肢 に来る障害が多いのに比して稀な症例である.84席は視 覚認識障害を主訴とした門脈大循環脳症でB型肝炎由来 と見做される青年例である．86席は劇症，正急性肝炎時 の䐺病変についてで，原因については粠炎合併の汪か DIC，循環障害，ステロイドホルモン使用による感染誘 発などの機序が考兄られている．87席は慢性肝炎に括け る脾腫の意義を脾と肝の計測を基にした保数によって他 の所見との相関を調べたものであるが，この係数は主と してマグロブリンの增加する状熊と関係が深いようであ る. 
88. 一過性に Monoclonal gammopathy (I gG-L type) を伴った肝硬変症の 1 例 川崎医科大学消化器内科

$$
\begin{aligned}
& \text { 山本瑟一郎, 山下佐知子 } \\
& \text { 大橋 勝彦, 平野 寞 }
\end{aligned}
$$

IgG-L 型のM蛋白血症が一過性に出現した肝硬変症の 1 例を報告した．忠者は51歳，男性で腹水之肝性皆睡の ため入院し，入院時蛋白分画で $\gamma$ 位に step-up pattern を認め，兔疫電気泳動でL型 Monoclonal IgG と判明 した．尿中ベンスショーンズ蛋白は陰性で骨破壊像を認 めず骨䯣腫の合併は否定された．入院後肔機能娭査の改 善とともに IgG $3,773 \mathrm{mg} / \mathrm{d} l$ から $2,352 \mathrm{mg} / \mathrm{d} l$ へと減 少し約 1 ケ月後にはM蛋白は消失し polyclonal pattern に変化した：このようにM蛋白血症が肝硬変の経過中に 一過性に出現し臨床経過の改善とともに消失したといら 例は他に報告がなく興味深いと考えられた。

89. 門脈型肝硬変症の 1 剖検例一連続切片に よる肝細胞壊死の検討

旭川医科大学第 2 内科

$$
\begin{array}{rr}
\text { 菅原 武久, 建部 高明, 石井 兼央 } \\
\text { 中同検查部 } & \text { 牧野 幹夫 }
\end{array}
$$

門脈型肝硬变症の 1 剖検肝を用いて連続切片を作成 し，肝細胞壈死の三次元的な抗がりを検討した，その結 果, 比較的大型の 結節塊では bridging necrosis によっ て結節は細分化，さらには孤立化される，又，比較的小 型の結節では，結節辺縁部を削门落すような肝細胞壊死 によって，さらに小型化する，そして，孤立した小さな 結節は，結節全体が壃死飞陥るというすのであった，以 上の壤死の組合せは，結節ネットワーク（高橋）を改変 させるものである. 一方でこのような結節ネットワーク の改变を生じつつ，もし他方で，残存する大型の結節が 肥大增殖するならば. 本症例のように, 先行する慢性肝 炎から「削り取り」的に進展したと思われる門脈型肝硬 变から, 粗結節型の乙型肝硬变への移行も生じ得るもの と推測された。

\section{0. 肝部下大静脈閉塞症の 1 例} 獨協医科大学第 2 内科

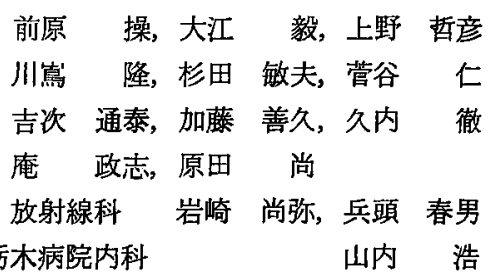

【症例】52歳男性，既往歷に特記することなく，1962 年頃より腹壁静脈怒張汇気付く. 1972年上り肝性脳症出 現し，以後数回くり返し，1979年 4 月精查のため当科汇 入院した，入院時，眼球結膜軽度黄染，肝脾は触知せ ず，腹部・前胸部に著明な上行性の静脈怒張，右側腰， 背部の静脈怒張，下肢に色素沈着あり，腹水 $(-)$, 浮 腫 $(+)$. 血液生化学検査では ICG $40 \%$ 以外著变なし。 腹控鏡では肝硬変症と診断. 静脈造影で下大静脈は横隔 膜直下より約 $5 \mathrm{~cm}$ とわたり閉塞を認め，正常の肝静脈 は造影されず，異常走行の副血行路を認めた．経皮経肝 門脈造影です著明な副血行路がみられた，以上，肝部下 大静脈閉塞症の 1 例を報告した。

\section{1. 特異な門脈下大静脈短絡を 呈した 肝性脳} 症の一例

東京都立駒込病院内科, 感染症科

原田 英治, 小町谷恭平，大竹 寛雄

由中 慧, 大林 明

胃冠状静脈と左腎静脈の短絡によりPortosystemic encephalopathy を起こした一例を報告する.

症例 : 54歳男, 45歳より失見当識を伴う意識障害を頻 回にくり返した.54歳本院受診時肝機能は，ほぼ正常で あったが意識障害時に高アンモニア血症を呈したので肝 性脳应を疑った，腹㚙鏡では軽度の萎縮した肝で，生㭘 組織像は軽度の線維化と脂肪沈着を認めるのみであっ た. 肝外側副血行路の存在を疑い，腹腔動脈造影，左腎 静脈造影を行ない.カテーテルが左腎静脈から胃冠状静 脈を経て門脈本幹にはいっていくことを確認した. 門脈 压は正常で，腹腔動脈系にも稀な分枝があることから， この短絡は先天性のものと考えられた. ラクッロースの 投与以来, 媨症の発症はみられていない。 
92. 特異な肝静脈造影所見を 示した特発性門 脈圧穴進症 (IPH) の 1 例

東京慈恵会医科大学第 1 内科

\begin{tabular}{|c|c|c|c|c|}
\hline & 山崎 & 一信, & 三枝 & 苗成 \\
\hline & 今井 & 深。 & 亀田 & 治男 \\
\hline 東京大学第 2 外科 & =川 & 俊二, & 樑沢 & 正樹 \\
\hline 順天堂大学外科 & & & 杉浦 & \\
\hline
\end{tabular}

肝静脈造影にて著明な肝静脈相互間吻合のみられた特 発性門脈圧穴進症 (IPH) の 1 例を経験した。症例は24 歳女性. 昭和53年 9 月睡眠中吐血をきたし近医に入院. 内視鏡㭘查で胃出血々診断されたが同時に食道静脈溜も 認められた. 䀒機能は略々正常. 白血球, 血小板減少. 脾腫を認め，直腸毛 紲管压は $340 \mathrm{mmH}_{2} \mathrm{O}$ と高値であっ た. 肝静脈造影では高度の肝静脈相互間吻合がみられ， WHVP は $102 \mathrm{mmH}_{2} \mathrm{O}$ であった. 又日本住血夢蚾内 反応は陰性. 肝生検では肝内異所性門脈が認められた。 以上より IPH と診断し食道離断, 摘脾術を施行した. 肝静脈相互間吻合の発達は日本住血吸虫症でよく見ら れるが, IPH でも presinusoidal portal block 飞関連し て生じ得るるとと思われる.

\section{Banti 症候群により巨大側副血行路を 呈} し，全身のクリプトコッカス症で死亡したー 例

\section{順天堂大学病理}

白田一誠，松本 俊治，福田 芳郎

同 消化器内科 小松 郁俊, 浪久 利彦

症例は29歳女性で肝線維症, 脾腫, 巨大側副血行路の 診断で外来通院中であったが肝性昏睡にて㗨急入院. 入 院時黄疾及び脎神経症状が認められた，入院後乏尿， Azotemia，甲状腺腫大，上肢の Tremorなどの症状がみ られ死亡した．剖検時肝は700g 之萎縮 し, 脾は $580 \mathrm{~g}$ で あった，肝外門脈は周径約 $6 \mathrm{~mm}$ 之細く側副血行路の周 径 $30 \mathrm{~mm}$ と対称的であった. microでは肝内門脈枝, 肝 外門脈の狭窄及び線維化が認められ，グリンン鞘に沿っ ての線維の增生があり，線維同士の連結もみられた。 し かし大部分には隐小葉の形成は認められず肝線維症之診 断した，血管造影で 側副血行路は，食道静脈瘤ではな く, 門脈から胃小弯側寒側を通り, 脾わん曲部さらに腎 静脈付近に下降する巨大なるのであった.
94. 門脈圧穴進症例におけるアンモニア 負 荷 試験成績について

東北大学第 1 外科

大和田康夫, 小山 研二, 高木 靖

大内 清昭, 松原 修二, 今岡 洋一

演者らは, 経口的アンモニア負荷試験成績を，血中ア ンモニア值が正常域内にとどまるものをI 型, 上年して

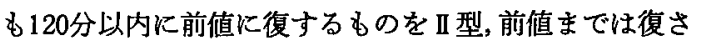
ないるのを而型，持続的に上昇するるのをIV型としてい る. また，負荷後のアンモ二ア值の総和を $\Sigma \mathrm{NH}_{\mathrm{s}} \mathrm{N}$ とし て倹討したところ，これは ICGK，BCAA/AAA モル比 など肝障害指標とよく相関した。 また門光症例ではII 型 は特発性門脈圧方進症例に多く, IV型忹肝硬変に多い が，IV型を示するのは䀒硬変の 重症例に多かった： たここれらの成績は単に肝外短絡のみを反映するだけで なく肝実質障害をも反映し門充症例の手術適応を決定す る際重視すべき検査である。その代表的症例を呈示する.

\section{座長ましめ（88～94）}

$$
\text { 獨協医科大学第 } 2 \text { 内科年内 徹 }
$$

88席 : 一過性に monoclonal gammanopathy を示した 肝硬変症が報告され本例と血液像から maltiple myeloma との関連性が討議され否定された. また 2 例の追加 報告がなされた８9席：門脈型肝硬変症の他の型への移 行が連続切片標本で検討され削り取りや bridging など が報告された. 偽小葉周辺部の変化の機序について質議 された. 90席 : 肝部下大静脈の約 $5 \mathrm{~cm}$ の閉塞が証明さ れ，副血行路，下肢色素沈着など 臨床像の特徽が 報告 された．肝癌の存在が質議された．91席：門脈圧六進を 伴わないで肝性脳症をくり返した症例の報告がなされ， endotoxin との関連性につき質議さた。 92席：日本住血 吸虫症が否定されV-V Shuntを認めたIPH の症例の 報告がなされ，Shunt の成因，異所性門脈との関連など が討議された.93席：肝外門脈狭窄と巨大副血行路を伴 万肝線維症の症例で, 狭寉の原因につき質疑され胆道系 炎症が示唆された. 94席：アンモニア負荷試験成績を四 型に分け肝外短絡のみでなく肝実質障害を反映し, 手術 適応に応用されることが報告された。 
95. 胃静脈瘤により発見された先天性肝線維 症の 1 例

旭川医科大学第 3 内科

矢崎 康幸, 関谷 千尋, 林 英樹

高橋 篤, 沼崎 彰, 暒㦑

富永 吉春, 並木 正義

36歳男性症例. 胃集検て偶然胃静脈瘤を発見され精査 のため当科に入院. 自覚症状はなく，肝を硬く三满指， 脾を 1 横指触知した. 肝機能検查上 AL-P 27.8, $\gamma$-GTP 752，LAP 647 と胆道系酵素の上其をみたが黄疾はない，

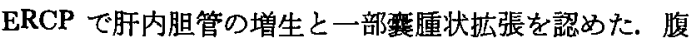
䏺鏡検査で肝は結節を認めないが著明な線維化を認め た. 生検組織では門脈域に幅広い、線維化と胆管の増生と の5腫状拡張，門脈枝の数の減少，㹟小化の所見を認め た先天性肝線維症と診断した。，小葉辺縁には胆汁色 素と線維の増生が みられ，同部位を電顕にて観察する と，抾張した滑面小胞体の增生と肝細胞括よび類洞内に は多数の胆汗㥞物質が認められ，類洞には多数の脂肪貪 食細胞と著明な線維の增生がみられた，尚，培胞腎も合 併していた。

96. 経皮経肝門脈造影 (PTP) により 診断され た興味ある肝部下大静脈閉塞症の一例

千葉大学第 1 内科

隆 元英, 飯田 真司, 後藤 信昭 岩間 章介，武者 広隆，小藤田和郎 奥田 邦雄

同 神経内科 河村 満, 平山 恵造 症例は46歳男性で歩行，構音障害を主訴とし，高アン $モ ニ ア$ 血症を示し，肝硬変症に伴なった肝性脑症と診断 された，大腿浮腫，腹水，腹壁静脈怒張はなかった，腰 推穿刺では純粋の血液が吸引された．PTP では門脈血 の脾腎短絡路，左腎静脈を介しての半奇静脈及び Internal Vertebral Plexus への流入を証明され，下大静脈閉 塞症と䛦断された。下大静脈造影飞て肝部下大静脈膜様 閉塞を確認すると共に左腎静脈の $\mathrm{Po}_{2}, \mathrm{NH}_{3}$ 值により機 能的にも脾腎短絡を証明した．Internal Vertebral Plexus が本例に於て短絡路を形成している点が特徽的で，腰推 穿刺に於て血液が吸引されることが，下大静脈閉塞症の 一症候であることを初めて報告した。

\section{7. 慢性非化脿性破墙性胆管炎の一例}

日本大学第 3 内科

荒川 泰行, 吉田 憲司, 勝原 徳道

具嶋 正倫, 加藤 昭, 本田 利男

同第 2 外科 森 要介, 根岸 七雄 和久井功司, 瀬在 幸安

同 病理

内田 俊和, 柄沢 勉, 志方 俊夫

症例は56歳の主婦， 2 年前より胆管系醉素の著増，高 脂血症, 肝腫大などがあり，某病院で胆道疾患が疑われ ていた．昭和53年 5 月当内科への第一回入院時の肝生検 で慢性肝炎類似の所見が認められた. 今回第二回入院時 の検查成績は GOT $147.6 \mathrm{mIU}$ ，GPT $86.6 \mathrm{mIU}$, LDH $345.6 \mathrm{mIU}$, T.Bilirubin $2.1 \mathrm{mg} / \mathrm{dl}$, Al-phos. $1,838.2$ mIU, LAP $843.5 \mathrm{mIU}$, T. Cholesterol $754 \mathrm{mg} / \mathrm{dl}$, IgG $2,370 \mathrm{mg} / \mathrm{d} l, I \mathrm{gM} 328 \mathrm{mg} / \mathrm{d} l, I \mathrm{IgA} 313 \mathrm{mg} / \mathrm{dl}, \mathrm{CH}_{50} 27.5$ $\mathrm{u} / \mathrm{m} l$, 血清総胆汁酸 $200 \mu \mathrm{M} / \mathrm{m} l \mathrm{~s}$, 血清銅 $242 \mu \mathrm{g} / \mathrm{d} l, \mathrm{HL}-\mathrm{A}$ 抗原 A9，BW 54などである。 また AMA， ASMA，RA， 抗核抗体，ミクロゾーム抗体，Cryoglobulin などはそれ ぞれ陽性であるが， HBs 抗原・抗体， HBc 抗体，LE 細胞之抗 DNA 抗体は陰性である. 外科的肝生検では chronic non-suppurative destructive cholangitis (Rubin) の組織像を呈した。

98. 高齫者にみられた P.B.C. の一例 東京医科歯科大学第 3 内科 小田 浩之, 妹尾 春樹, 飯田 吉隆 畔上 信久，田中 明，関根 正明 前沢 秀憲

同第 1 外科 長井 章, 吉田 隽

同 中検病理 藤原 陸憲, 青木 望

症例は76歳, 女. 昭和53年 5 月頃発黄, その後軽快を みず，11月 1 日当科へ入院. T-Bil，Al-P， $\gamma$-GTP の上 昇が著明であったが直接胆道造影で肝外胆道閉塞は否定 された，消化管の検索では食道静脈瘤を認め，又，抗 ミ トコンドリア抗体陽性，Ig-M やや高值であることから P.B.C. を疑って外科的生検を施行. 肉眼的に肝は結節 形成を認めず，表面は緑色調はなく茶褐色やや斑状，生 検組織では肝の基本構築に乱れはなく，グ鞘の線維化も 軽度だが，中等大小葉間胆管の消失，形質細胞，リン パ球を主とした細胞浸潤，細胞管增生，一部に肉芽盾様 の部も認められ, Scheuer 分類の第 2 期の組織所見に相 当する P.B.C. 例と考光られた。 
99. 低 $\gamma$-グロブリン血症を伴った肝内胆汁う っ滞の 1 例 北海道大学第 3 内科 田村 康史, 武田 良一, 藤本比沙雄 前久保博士, 大屋 隆介, 松嶋 喬 宮崎 保

症例30歳：男性.S53.12.26黄疸と皮膚癌痒感出現 ᄂ 某医入院. Pred. $30 \mathrm{mg}$ 投与するも黄疸增強の為， S 54 . 2. 14 当科転院. 入院時検查成績：WBC 13,000 (Ly12, Eos $1 \%$ ) T. Bil $17.6 \mathrm{mg} / \mathrm{dl}$, GOT $189 \mathrm{IU} / l$, Al-P 42.9 K.A., T. chol $973 \mathrm{mg} / \mathrm{d} l$, T.P. $5.3, \gamma$-gl $0.20 \mathrm{~g} / \mathrm{d} l$, IgG 475, IgA 112, IgM 82mg/dl, AMA (-), ANF (-), CH $5039.2 \%$, PPD (-), E-Rosette $69.2 \%$, EACRosette 22.6\%, PHA-response 19.6. ERCP で胆道系 異常なし、肝生検で毛細胆管に胆汗栓散在, 細胞浸潤任 とんどなく線維増生なし. 黄症改善後も低 $\gamma$-gl 血症は 持続しているが，家族調查，各種予防接腫に異常なく， 薬剤アレルギーの既往なく，続発性免疫不全と考学られ る. 本症の成因に免疫学的な機序の関与が推定された.

\section{0. 姉妹に認められた PBC 2 症例 千葉大学第 1 内科}

伊藤上しみ，伊藤 文憲，河野 邦彦 小俣 政男，武者 広隆，小藤田和郎 奥田 邦雄

国立佐倉病院橋爪 藤光, 宮島 哲也 近年 PBC は稀な疾患ではなくなっているが，家族内 で発症している例は稀である. 我々は姉姝二人に PBC

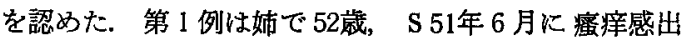
現, 8 月には黄㾝, 肝機能の異常を指摘された. 抗ミト コンドリフ抗体，平滑筇抗体陽性， IgM 著明に上昇が 認められた。第 2 例は43歳の妹. S 51年 1 月上り瘦痒感 出現，S53年 1 月に肝機能の異常を指摘された. 抗ミト コンドリア抗体陽性, IgM 上昇, 総コレステロール值 の著明な上昇があった. 上記 2 例は組織学的にも $\mathrm{PBC}$ の所見であった. 又我々は本症例及び他 PBC 4 例につ いて HLA を検索した. 今回は症例数が少ないこともあ $\eta$, HLA 抗原の分布に特徵を見い出し得なかった。
らが，症例の母親は大酒家か不かが質問があったが，家 族内に大酒家はいなかったとのこと、な打電顕にて, fat storing cell の增加が認められて打り，肝細胞壊死 を伴わない肝内線維増生との関係に注目しているとの考 えが述べられた。

96席 : 門脈が肝血流の流出路となっていることの詳細 な検討があった。

97席〜100席は肝内胆汁らっ滞（PBCも含む）の発表 で，とくに PBC は黄序とかゆみを訴える症例では本症 も考慮した諸検索が必要なことが再確認された．100席 はPBC の姉姝例の非常にまれな症例の報告で，最近九 州大学内科からも同様の報告がみられるが（日内会誌 68 (10）：1349，1979)，PBC では家族内の検索す重要な ことを示していると考党る.100席の姉妹には共通した HLA 抗原ハプロタイプが存在するのかの䧍索を施行中 との追加があり，その結果が注目されよう。

\section{CT スキャンの肝疾患診断における有用 性亡その限界}

都立大久保病院内科 安楽岡 滋, 川合 真一, 田中 義 森実 敏夫, 和田伊津子, 加藤 督介 高林 洋一, 高橋 日和, 里和 $ミ$ ミ 龟谷麒与隆

同 放射線科 木下 文雄, 前川 全, 高木八重子 昭和52年12月より現在まで経験した肝細胞癌 26 例, 癌の肝転移 62例, 肝膿演 2 例, 肝の5胞 21 例に EMICT 5005を使用し，その診断能と限界につき検討した。 肝のう胞・肝膿湯はかなり小さなものまで良く描出さ れ，治療効果の判定にも有用であった，しかし充実性腫 瘍で每る肝細胞癌・癌の肝転移例では，正常肝組織之の X線吸収差が小さいため読影がかなり困難な場合むあ り, Window 值をせまく校って正常肝と病巣の Contrast を明瞭にさせる操作が診断率を左右すると思われた。 し かし，それでも読影困難で肝シンチグラム・肝動脈造影 にて診断された症例も数例程認められ，CT スキャンに よる猃断的限界もあった。
座長まとめ $(95 \sim 100)$

東京医科歯科大学第 2 内科蓮村 靖

95席 : 成人の先天性肝線維症は非常にまれであると思 
102. 肝胆道系疾患における CT スキャンの診

\section{断的意義}

埼玉医科大学第 3 内科

宮沢美智子, 山羽 義貴, 松尾 秀一

矢部 諭, 一戸 彰, 伊藤 進

同放射線科坪郷 義崇

過去 1 年間に 当科に入院した肝胆道采疾患患者のう ち，剖検，手術，腹腔鏡，肝生検によって診断の確定し た51例（原発性肝癌11例，転移性肝癌 11例，肝震胞 1 例, 肝硬变 10 例, 原発性胆汁性肝硬変 1 例, 脂肪肝 2 例，その他15例) の CT 所見と， RI 検査，超音波，血 管撮影を比較検討した， mass lesion においては CT が mass の発見に役立ち, 剖検と比較して $2 \mathrm{~cm}$ 以上の病巣 はCTで確認し得たが，原発性と転移性との鑑別は困 難であった. cyst と tumor の共存例ではとの各々が鑑 別し得た。䀒硬变の診断においては，CT，超音波， RI 検査の間に有意の差は見られなかった，脂肪肝において は吸収值の差より，他疾患に比してCT が診断に有利で あると思われた。

\section{3. 肝疾患における CT スキャンと RI スキ} ャンの有用性の臨床的検討

東京都養育院付属病院核医学放射線部

野口 雅裕, 飯尾 正宏, 川口新一郎

大竹 英二, 戸張 千年, 村田 啓

千葉 一夫，山田 英夫

昨年 1 月より本年 9 月までに施行した上腹部 CT ス キャンは，255例で， らち1ケ月以内に RI スキャンむ 合せ施行したもの120例 (47.1\%)，また1ヶ月以内に CT スキャンと肝スキャンの両検査を施行したすの112 例 $(43.9 \%)$ であった. SOL の検出率は，肝スキャン の方が高かったが，肝内胆管执張例・胆のら位置異常等 を含む可能性があった，肝内病変の質的診断では，CT スキャンによる肝癌と肝のう尰の鑑別可能な点があり， 肝硬変に代表されるびまん性肝疾患の診断には，生理学 的イメージの肝スキャンの方が，まさっていた。拉い に，相補的な検查であるといえた。

\section{4. 原発性肝癌の CT について} 東京遁信病院放射線科

同 消化器科

三尾 明彦，大島 敏美

土井 優子, 福田 龍子, 藤樹 敏雄 橋本 英明, 高橋 一江, 兼高 達式 藤原 郁夫

11例の原発性肝癌について，第 2 世代の CT，ACTA $200 \mathrm{FS}$ を用い，正常肝之病変部之の吸收值差を中心梌 討した，その結果高吸収值差を示した群が 5 例，低吸収 值差群が 4 例，retrospective にみても病変を指摘できな い群が 2 例あった．吸收值差及び病変の大きさと病変の 認識との関係をみると，大きさが $3 \mathrm{~cm}$ ，吸収值差10EMI 単位以下の病変は初回検查時に見逃されていた。初回 検查時に病変を指摘できなかった 5 例のうち， 3 例は retrospective に narrow window で観察することで指摘 可能であった. contrast enhancement の効果を8例につ いて検討したが，5例か： $\mathrm{CE}$ 効果 $(+) ， 2$ 例は不変, I 例は CE 後に正常部より病変部の吸收值が增加し病

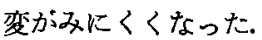

\section{5. 原発性肝癌の CT 診断の検討} 北海道大学第 1 外科

$$
\begin{aligned}
& \text { 及能 健一, 河西 紀夫, 佐藤 } \\
& \text { 直樹 } \\
& \text { 杵田 隆久, 平良 健康, 玉置 明 } \\
& \text { 葛西 洋一 }
\end{aligned}
$$

原原性肝癌の CT 診断の意義について検討した，対 象は原発性肝癌16例であるが，他の限局性肝疾患（肝包

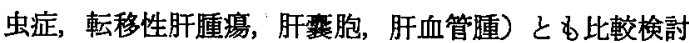
した. 全例術前 1 ケ月以内に CT を施行し，その所見 を手術ならびに組織所見と対比検索した．原発性肝癌て 鮮明な低濃度域を呈したものは 9 例，不鮮明なむのは 4 例，診断不能なるのは 3 例であった，病巣の CT 值, 病巣之非病巣肝との CT 值の比の計測, をた contrast enhancement を行ならことにより他の限局性肝疾患と の鑑別が可能であった，組織所見を検討すると，CT で の病巢の鮮明度と畽瑒の变性罗死の程度と関連がみられ た.また CT では，プラニメトリーにより，切除後の 残存肝量の容積予湘も可能であった。

座長まとめ $(101 〜 105)$

東京都盖育院附属病院飯尾 正宏 日本は現在，脳，全身用を含めて500台を越える CT 
を保有し，世界で最もCT 密度の高い国である（UK8， ベルギー0, USA 700台余). 即ら, 肝疾患の䛦断に際 し，超音波，肝スキャンなどと全く対等に伍して活用さ れらる技術となって居り，技術および読影法に関し，会 貝の理解が望まれる。

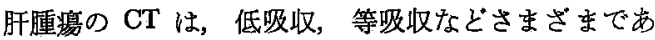
り，造影剂注入後も必らずしも高吸収部とはならない。 CT のウインドウ幅を狭くし，読影診断率を高める必要 のあることが強調された，全体としての猃断率は，超音 波，RI スキャンに比し，決して高いものでない。これ らの検査にひきつづいて行われるべき検查である点，演 者間の意見は一致した。 しかし, 肝内胆管の拡張, 藻胞 症，膿場などの診断には感度が高い，CT 所見よりの肝 腫㝝の分類や，その組織所見についての考察が試みられ たが、いずれる決定的なるのではない，切除残存肝量の 測定も試みられた。

\section{6. リニヤ電子スキャンによるび漫性肝疾患}

\section{の超音波診断}

千葉大学第 1 内科

高橋 法昭，木村 邦夫，松谷 正一 木村 道雄，江原 正明，五月女直樹 野口 武英，土屋 幸浩，税所 宏光 大野 孝則，大藤 正雄，奥田 邦夫

急性肝炎11例，慢性肝炎32例，肝硬变63例を対象之乙 た. (1) 表面像 : 平滑と不整凹凸㭭されるが，肝硬 変では76\%に不整回凸を認めた。一部急性肝炎，慢性肝 炎炕子不整凹凸を認めた。 (2) 肝縁像：鈍化，鋭利化な どの不整所見は肝硬変では全例汇，僈性肝炎では少数に 認められた．哃面突出像性，急性肝炎，慢性肝炎の一部 飞認められた. (3) 内部像 : 不規則斑状エコー像は，肝 硬変においてのみ $26 \%$ に描出された. (4) 脾腫：急性肝 炎の急性期，慢性肝炎では $38 \%$ ，肝硬变では $83 \%$ に認め た。最後に，超音波像に上る門脈压六進症症例を供らん した.

\section{7. 超音波ドプラー法による 肝疾患の診断一 臨床的検討 \\ 旭川医科大学第 2 外科 \\ 葛西 真一, 大西 俊郎, 水戸 妯郎}

肝疾患時江，その病態に対疬して肝血行動態が変化す ることは古くから知られている。一方，超音波ドプラー
法が，生体無侵㜔性に血流变動を検知できることから， われわれは，本法の肝疾患の診断法としての有用性を㭘 討してきた，症例は，正常（18），原発性肝癌（34）, 転 移性肝癌 (12), 肝硬変 (38), その他 (19) で肝ソナグ ラム上の最高，最低周波数就よび包絡線の性状について 比較した. その結果, 限局性肝腫瘍とくに原発性肝癌に おいて，最も特徵的なパターンを示し，猃断法として有 用であることが判明した。 また，本法が，術中の肝動脈 結禁の確認や，術後の副血行路増生過程の判定にも有意 義であることを述べた.

\section{U.I. OCTOSON による肝疾患の 超音波 診断 \\ 北海道勤労者医療協会}

美馬 聰昭, 水尾 仁, 田辺 利男
羽二生輝樹, 河内 秀希

旭川医科大学第 3 内科関谷 千尋 札幌医科大学癌研内科福田 守道

超音波による映像訩断法は，装置の急激な進歩に上 り，肝疾患の診断的るきわて重要な情報を提供できる よらになった．Kossoff によって開発された全自動超音

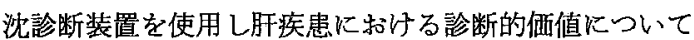
検討した.

装置は, Ausonic 社, U.I.OCTOSON で，記録には 三共電機社製，multiformat を連結し，6切フイルムに 記録した．横断面断層像は，前上腸骨棱面を，矢状面断 層像は，正中面を基準とし，10mm 刻みで記録した。 原発性肝癌，転移性肝癌，肝膿瘍，肝の弓胞，肝包虫 症，肝硬変の典型的画像を供覧した，本装置は，CT を 含めた映像診断法に関して，今後重要な位置を占めるも のと思われる.

\section{9. 肝占居性病変と超音波診断 虎の門病院消化器科}

竹内 和男, 山田 直行

同 放射線嗙断学科煎本 正博

確診の得られた49例（ヘパトーマ14，転移性肝癌22， 肝整胞性疾患 9，その他 4）を対象とし，ェュー・肝シ ンチ・Angio での診断能を検討した，存在診断率は，ェ コー79, 肝シンチ91, Angio 92\%であった。エコーは, 整胞性疾患では100\%であったが，充実性病变では75\% で，険查不良や見和としが少からずあり，問題点之考古 
られた：エコーの質的診断率は，巽胞性疾患では $89 \%$ と すぐれ，充実性病変でも70\%に，へパトーマ，肝転移等 の質的診断が可能であった。

スクリーニングとしては，被検者の条件や検查の経験 によらない肝ンンチの方がり適当と考えられたが，肝 シンチでの偽欠損の鑑別に有用であること，肝病変以外 の臨床的に有益な情報が得られたこと，ェコーのみ陽性 であった例るみとめられたこと等より，ェューの䛦断的 意義は大きかった。

\section{0. 肝細胞癌の 超音波診断一病理所見との対} 比検討

千葉大学第 1 内科

野口 武英, 木村 邦夫, 高橋 洗昭 五月女直樹, 木村 道雄, 江原 正明 松谷 正一, 土屋 幸浩, 税所 宏光 大野 孝則, 大藤 正雄, 奥田 邦雄

病理剖検所見(肝細胞癌11例, 転移性肝癌 2 例) と》 こア電子スキャンによる超音波像との対比検討を行い， その所見をるとに，肝細胞癌34例，転移癌35例について 超音波像の検討を行い，腫場 Echo 像を 4 型に分類し た. 肝紐胞癌では, I 型 (単結節型) 6 例， 17.6\% II 型（融合塊状型） 11 例， $32.4 \%$ III型（多結節型） 3 例， $8.8 \% ， \mathrm{IV}$ 型 (びまん型) 14例，41.2\%であったが， 転移癌は汪とんど型34例，97.1\%で占められていた。 又, 腫湟内部 Echo 像は, 肝細胞癌では Mixed, Rich が多かったが，転移癌は恬とんど vichであった．門脈 内腫瘍塞栓像は, 肝細胞癌の61.8\%腹められたが, 転 移癌では認められなかった，以上より超音波上，多くの 例で肝細胞癌と転移癌の鑑別が可能であった。

\section{1. 原発性肝癌の診断における 超音波検查法 の有用性}

金沢大学第 1 内科
岩田 章, 池田 正, 中源
雅俊
小熊谷 幹男, 加登 康洋, 沢武 紀雄
小林 健一, 服部 信
同 核医学科
同 放射線科

金沢大学第 1 内科任入院した原発性肝癌 41 例につきり 二フ式電子走查型装置に上る超音波検査法 (US)の原発 性肝癌訅断における有用性を恰討した. US にて肝内限
局性病变を検出乙克たのは16例中13例 $(81 \%)$ で, 盰ン ンチグラフィーとほぼ同様の診断率であった．肝シンチ グラフィーにて異常を指摘できず，US で診断された例 が1例みられた。従来の腹腔動脈造影飞 Infusion hepatic angiography を併用した場合より診断率は低かった が, US と肝シンチ, AFP, rGTP isoenzyme を組合せ ると診断率は向上した，US は負担が軽く手軽に施行で き, 病変の部位, 質的診断も可能で, 胆管, 門脈の状態 も知ることができ，原発性肝癌のスクリーニングに有用 であると思われる.

\section{座長まとめ（106～111）}

千葉大学第 1 内科 大藤 正雄

超音波検査は簡単で患者への負担を与えす優れた診断 能をもつことが各種検查法との対比により明らかとされ た.

びまん性肝疾患，とくに肝硬変の喰断にも応用が可能 であるとされた。

限局性病変の診断では病変の検出率においてアイント ープスキャンやCT，血管造影に劣るが病変の性質を精

しく判定するものに役立つことが明らかにされた。

な特 positive accuracy に劣り negative accuracy $K$ 優るアイットープスキャンを先ず行い，次いで検查法と してその反対の性質をむつ超音波検査を行らことにより 病変がもれなく高率に診断できることが明らかにされ た. 今後超音波検查法は装置の工夫, 改善により negative accuracy の向上が期待できるとされた.

\section{2. 肝・胆道疾患の診断的意義一CT スキャ} ンを中心に 岩手医科大学第 1 内科 小野寺久勝, 海藤 勇, 佐藤 俊一 中沢 一臣, 小坂 陽一, 小豆島正和 紫桃 正裕, 阿部 裕行, 加藤 章信 盛岡赤十字病院放射線科

松岡 昭治, 鈴木 俊信

CT スキャンは EMI-5005で行なった。原発性肝癌12 例は病変部の 辺縁不整な低濃度域の 所見より10例（83 \%) が診断可能, 融合塊状, 多結節型の 2 例が診断困難 であった. 転移性肝癌14例中13例（93\%）は円形明瞭で 多発性の低濃度域上り診断は可能であるが，単発性の1 例を誤診した. 悪性閉塞性黄疸は胆管を上部（胆のら管 
含む)，中部，下部（膆頭部含む）飞分けて行なった。 閉塞部位の推定されたものは 14 例中10例 (71\%)，質的 診断が可能であったもの7 例（50\%）であり，下部に不 能例が多い，誤診 3 例（22\%）は転移巣を主病巣之誤っ た症例である.な㧍，良性閉塞性黄疸の質的診断率は約 $3 \%$ あっった.

\section{3. 肝門部門脈閉塞及び 狭窄のみられた 5 症} 例の $\mathbf{X}$ 線及ひ超音波像との対比検討

\section{国立千葉病院内科}

高安 賢一, 小林千鶴子, 加藤 二郎 千葉大学第 1 内科

隆 元英, 武者 広隆, 奥田 邦雄

対象は全例門脈圧六進を呈する女4, 男 1 の計 5 例 である.PTP 像を主に上腸間膜動脈静脈相等で認めた 肝門部附近の門脈断裂 3 例, 狭窄 2 例火ついて門脈本幹 及び肝内門脈系静脈所見を合せて超音波像と対比倹討し た. 肝門部及び門脈本幹での所見は両者で 4 例 $(80 \%)$ が一致し，肝内門脈系静脈では血管の走行及び血管径で 比較的よく一致したが， $\mathbf{X}$ 線像では肝皮膜下の Cut-off 所見が 4 例にみられ超音波像では血管周囲に軽〜中等度 の strong echo が 4 例にみとめられた. 両者を比較する と PTP 法は全体像なかです皮膜下や左右肝で異なる血 管走行等の把握に優れ，超音波は血管周团の細かい病変 をとらえるのにその非侵億性る加えて優れていると思わ れた.

114. リニア電子スキャン超音波装置による肝 内胆汁うっ滞と閉塞性黄㾝 の鑑別一特にその 基礎としての超音波胆管径と $\mathbf{X}$ 線胆管径との 比較検討

千葉大学第 1 内科

五月女直樹, 土屋 幸浩, 松谷 正一

野口 武英, 木村 道雄, 高橋 法昭

江原 正明, 木村 邦夫, 税所 宏光

大野 孝則, 大藤 正雄, 奥田 邦雄

\section{国立横浜東病院}

唐沢 英偉, 三木 完, 上野 高次 船橋中央病院

黄疸の鑑別に対する超音波の有用性を倹討した，対照 群40例, 閉塞性黄疸89例, 肝内胆汁亏っ滞22例を対象と した。超音波胆管径はX線胆管径とよく相関したリン

ア電子スキャンにより正常胆管は高率に描出され，左右 肝管は平均 $1.7 \mathrm{~mm}$, 総肝管は平均 $3.3 \mathrm{~mm}$, 総胆管は平均 $3.0 \mathrm{~mm}$ であった。閉塞性黄疸は総肝管で平均 $17.1 \mathrm{~mm}$, 肝内胆汁らっ滞では平均 $3.4 \mathrm{~mm}$ と明らかに差が認めら れ，胆管径の計測により $99.1 \%$ に黄瘪の鑑別が可能であ った. さらに閉塞性黄疸について閉塞部位及び閉塞性病 変の描出についても検討を加党た。

\section{5. 肝内胆石症の超音波診断および超音波映 像下 PTC の検討}

千葉大学第 1 内科

$$
\begin{aligned}
& \text { 松谷 正一, 土屋 幸浩, 木村 道雄 } \\
& \text { 江原 正明, 五月女直樹, 高橋 法昭 } \\
& \text { 野口 武英, 木村 邦夫, 淞所 究光 } \\
& \text { 大野 孝則, 大藤 正雄, 奥田 邦雄 }
\end{aligned}
$$

肝内胆石症に対する超音波診断能を检討しその有用性 を明らかにした。

1. 肝内胆石症の存在診断関して IVC $50 \%$, ERC $79 \%$ ，PTC 95\%，US 100\%と超音波検査が最もすぐれ ていた.

2. 超音波検查は従来の_PTC，ERC で造影不可能で あった部位の胆石像をる描出できた。

3. 超音波映像下 PTC は病変部胆管を確実に描出す ることができた。

4. 超音波検查及び超音波映像下 PTC の併用は肝内 胆石の全体像を明らかにすることができ，猃断能の向上 に有用であった。

116. エヒノコックス症の診断における CT スキャンと超音波検查の有用性 北海道大学第 2 内科

鎌田 吉和，渡辺 正夫，山口 彰 管崎堅次郎, 牧野 勲, 中川 昌一

今回, 我々は血清反応和よび試験開腹によりェヒノコ ックス症と確定診断した症例 (44歳女性, 北海道夕張市 在住）の肝シンチグラムにおける巨大 SOL について, CT スキャン, ェューCAG の検索を行ない，それらの 結果を比較検討した．CT スキャンでは density 13の low density area であり, hepatoma か abscess ェュー では内容が液体でなく, solid mass, CAG では cyst と 病変兴断は諸娭查で全く一致をみなかった。このこと は, 各検査法が病変の一端を反映しているものの, 総合 
的な所見をとら兄得ないためであり，肝胆道病巣の診断 にあたっては検査法の特性を十分にらをえた上で結果を 考察することの重要性を示唆している。

\section{7. 肝占拠性病変の映像診断の比較・検討} 東京慈恵会医科大学第 3 分院内科

$$
\begin{aligned}
& \text { 矢野 満, 牛尾 剛雄, 熊谷 慶子 } \\
& \text { 柴田 正純, 藤沢孝一郎, 高沢 勤 } \\
& \text { 植木 秀実, 相沢 健彦, 永山 和男 } \\
& \text { 小沢 靖, 堀口 正晴 }
\end{aligned}
$$

肝占捕性病变のらち肝膿瘍, 肝のら疱, 肝血管腫, 肝 皮膜下血腫を伴う原発性肝癌の 4 症例について, シンチ グラム，エコーグラム CT，血管造影を施行し，描出さ れるパターンを比較することにより各椧查の診断能と特 徵について検討したので報告する.

座長まとめ（112～117）

東京警察病院内科 右田 徹
位診断について正診率を集計しているが，CT でも診断 の困難な症例の少なくないことは銘記されるべです る.

113席. 肝外門脈閉塞の超音波像炕ついて報告, 腹部 超音波猃断の分野を拡大する意味で評価されよう。

114席. 対照群と胆管閉塞群について，超音波像の胆 管径を計測し，胆管拡張 $(7 \mathrm{~mm})$, 閉塞性黄疸 $(15 \mathrm{~mm})$ の制定指標を示したが，臨床的に利用価值が高い資料と 考学られる。

115席. 肝内胆石の胆石エュー像による診断率の高い ことを示し，誤診例として Pneumobilia が愦陽性であ った．追加発言（新大内科）で CTにより両者の鑑別 が可能との主張あり.

116席，117席. 肝シンチグラムで占居性病变を示す5 疾患のエコー，CT，CAG 上の imxge の特徽をわげ， 各検查法の特性を配虑して，綜合的に訩断すべきことが 示唆された.

112席. CT Kよる肝癌の存在䛦断と閉塞性黄疸の部 